\title{
Evaluating Inorganic Feed Phosphate Type and Further Potential of Phytase Supplementation using a Commercial Broiler Model
}

Angela Elsie Lamp

West Virginia University, alamp@mix.wvu.edu

Follow this and additional works at: https://researchrepository.wvu.edu/etd

Part of the Other Nutrition Commons, and the Poultry or Avian Science Commons

\footnotetext{
Recommended Citation

Lamp, Angela Elsie, "Evaluating Inorganic Feed Phosphate Type and Further Potential of Phytase Supplementation using a Commercial Broiler Model" (2020). Graduate Theses, Dissertations, and Problem Reports. 7615.

https://researchrepository.wvu.edu/etd/7615

This Dissertation is protected by copyright and/or related rights. It has been brought to you by the The Research Repository @ WVU with permission from the rights-holder(s). You are free to use this Dissertation in any way that is permitted by the copyright and related rights legislation that applies to your use. For other uses you must obtain permission from the rights-holder(s) directly, unless additional rights are indicated by a Creative Commons license in the record and/ or on the work itself. This Dissertation has been accepted for inclusion in WVU Graduate Theses, Dissertations, and Problem Reports collection by an authorized administrator of The Research Repository @ WVU. For more information, please contact researchrepository@mail.wvu.edu.
} 


\title{
Evaluating Inorganic Feed Phosphate Type and Further Potential of Phytase Supplementation using a Commercial Broiler Model
}

\author{
Angela Elsie Lamp \\ Dissertation submitted \\ to the Davis College of Agriculture, Natural Resources, and Design \\ at West Virginia University \\ in partial fulfillment of the requirements for the degree of \\ Doctor of Philosophy in \\ Animal and Food Science \\ Joseph Moritz, Ph.D., Chair \\ Janet Tou, Ph.D. \\ Zachary Freedman, Ph.D. \\ Robert Loar, Ph.D. \\ Department of Animal and Nutritional Sciences
}

Morgantown, West Virginia

2020

Keywords: Phytase, Inorganic Feed Phosphates, Broiler, Nutrition, Diet Formulation Copyright 2020 Angela E. Lamp 


\section{ABSTRACT \\ Evaluating Inorganic Feed Phosphate Type and Further Potential of Phytase Supplementation using a Commercial Broiler Model}

\section{Angela Elsie Lamp}

Optimizing feed formulation of poultry diets may be achieved by proper utilization of nutrients and feed additives. This will provide a less expensive and nutrient efficient diet to the bird. An experiment was conducted to evaluate early broiler performance, tibia mineralization, and mineral digestibility of broilers fed diets that differed in inorganic feed phosphates (IFP) but that were formulated to be either similar in dietary non-phytate phosphorus (nPP) and calcium to phosphorus ratio $(\mathrm{Ca}: \mathrm{P})$, total mineral content, or calculated prececal digestible phosphorus (CPDP). Dicalcium phosphate (DCP), monodicalcium phosphate (MDP), monocalcium phosphate (MCP), and defluorinated phosphate were used in formulations with similar nPP and $\mathrm{Ca}: \mathrm{P}$. In addition to these four treatments, a mixture of MCP, monosodium phosphate, and DCP was used to assimilate total mineral content of MDP (DMM). Moreover, a mixture of MCP and silicon dioxide was used to produce a similar CPDP as the DCP diet $\left(\mathrm{MCP}+\mathrm{SiO}_{2}\right)$. The $\mathrm{MCP}+\mathrm{SiO}_{2}$ diet had the lowest IFP inclusion. The study utilized a randomized complete block design with ten replications of ten male broilers fed each of six dietary treatments for 21 days. Linear contrasts were utilized to compare treatments of interest. Birds fed MCP demonstrated increased live weight gain, tibia ash (mg/chick), and mineral digestibility compared to DCP when diets were formulated to similar nPP and Ca:P $(\mathrm{P}<0.05)$. When diets were formulated to similar total mineral content, MDP fed birds had an increase in tibia ash (\%) and mineral digestibility compared to birds fed DMM $(\mathrm{P}<0.05)$. Birds fed $\mathrm{MCP}+\mathrm{SiO}_{2}$ had increased mineral digestibility compared to birds fed DCP when diets were formulated to similar CPDP ( $<<0.05)$. Dietary inclusion and efficacy data suggest that diets formulated using CPDP may optimize feed $\mathrm{P}$ incorporation and utilization.

A second experiment was conducted to evaluate correlations between in vitro phytase activity post pelleting and broiler performance, tibia mineralization, and plasma myo-inositol of broilers fed diets containing different phytase enzymes conditioned at three different temperatures $\left(70,80\right.$, and $\left.90^{\circ} \mathrm{C}\right)$. Dietary treatments included a positive control (PC; $0.9 \%$ calcium $(\mathrm{Ca})$ and $0.4 \% \mathrm{nPP}$ ) and negative control $(\mathrm{NC} ; 0.7 \% \mathrm{Ca}$ and $0.2 \% \mathrm{nPP})$ and four additional diets containing commercially available phytase products (A, B, C, and D) added to the NC based on analyzed activity and manufacturer's recommendations. Treatments were arranged in a 6 (diet formulation) x 3 (conditioning temperature) factorial in a randomized complete block design with ten replications of ten male broilers fed each of 18 dietary treatments for 21 days. Correlations were determined with categorical and replicated data. A conditioning temperature $\mathrm{x}$ diet formulation interaction occurred for $\mathrm{d} 14$ and 21 FCR and $\mathrm{d} 21$ tibia ash $(\mathrm{P}<$ 0.05). Day 14 and 21 FCR increased and $\mathrm{d} 21$ tibia ash decreased as conditioning temperature was increased from 70 to $90^{\circ} \mathrm{C}$ for all phytase treatments except Phytase B that did not demonstrate performance or tibia ash detriment. Correlations were most apparent with replicated data. In vitro Phytase A activity correlated with d21 FCR ( $\mathrm{P}=0.04, \mathrm{r}=-0.38)$, Phytase $\mathrm{B}$ did not demonstrate correlation $(\mathrm{P}>0.05)$, Phytase $\mathrm{C}$ correlated with tibia ash $\mathrm{mg} / \mathrm{chick}(\mathrm{P}=0.01, \mathrm{r}=$ 0.46), and Phytase D showed a moderate correlation with tibia ash $\mathrm{mg} / \mathrm{chick}(\mathrm{P}=0.16, \mathrm{r}=0.26)$ and plasma myo-inositol concentration $(\mathrm{P}=0.15, \mathrm{r}=0.27)$. This study did not demonstrate a common in vivo performance metric that was correlated with in vitro phytase activity post 
manufacture among commercial phytase products that decreased in activity due to increased conditioning temperature. Both in vivo and in vitro measurements should be assessed to properly evaluate the efficacy of an enzyme.

The third and final study conducted was conducted to determine the ME release of a commercial phytase fed to broilers at multiple doses in basal diets that varied in ME. Dietary treatments included three negative controls (NC; $0.75 \%$ calcium and $0.30 \%$ non-phytate phosphorus) formulated at three ME levels (2701, 2868, and $3000 \mathrm{kcal} / \mathrm{kg}$ ). A commercial phytase product was added to each NC diet at 1500, 4500, 13500, and $30000 \mathrm{FTU} / \mathrm{kg}$, creating a total of 15 dietary treatments. Treatments were arranged in a 5 (phytase dose) x 3 (ME level) factorial in a randomized complete block design with nine replications of ten male broilers fed each of 15 dietary treatments for 21 days. Alpha was designated as 0.05 for significance and 0.10 for trending data. For all measurement periods (d7, 14, and 21), FCR decreased as ME increased $(\mathrm{P}<0.0001)$. On $\mathrm{d} 21$, ending bird weight and live weight gain (LWG) increased with the addition of phytase and as ME increased $(\mathrm{P}<0.05)$. Furthermore, the addition of phytase significantly improved d14 and 21 FCR $(\mathrm{P}<0.05)$. Trends were observed for ME level x phytase dose interactions for $\mathrm{d} 41$ and $21 \mathrm{FCR}$. These trends demonstrate that phytase is most beneficial with the low energy diets. Eight treatments were selected for AMEn analysis based on d14 and $21 \mathrm{FCR}$ data; AMEn ranged from 2773 to $3457 \mathrm{kcal} / \mathrm{kg}$. Diets formulated at $2701 \mathrm{kcal} / \mathrm{kg}$ dosed at 1500,13500 , and $30000 \mathrm{FTU} / \mathrm{kg}$ released $114,-179$, and $-2.76 \mathrm{kcal} / \mathrm{kg}$, respectively. Whereas, diets formulated at $2868 \mathrm{kcal} / \mathrm{kg}$ dosed at 1500 and $13500 \mathrm{FTU} / \mathrm{kg}$ released 281 and $423 \mathrm{kcal} / \mathrm{kg}$, respectively. Contrary to past studies, clear results were not observed for the energy releasing efficacy of graded levels of phytase. Performance improvements with phytase supplementation were likely more associated with $\mathrm{P}$ availability than AMEn availability. 


\section{ACKNOWLEDGMENTS}

I would first like to thank my advisor and major professor Dr. Joe Moritz for his mentorship, friendship, and support throughout my educational career. The opportunities he has provided me have shaped the person I am today. I would like to thank the other members of my committee: Drs. Janet Tou, Zachary Freedman, and Robert Loar. I cannot thank you enough for your time and mentorship; you have helped me succeed throughout this entire process. I would also like to thank the past and present members of Dr. Moritz's research group: Niles Ridgeway, Victoria Ayres, Tim Boltz, Talman Hylton, Kari Harding, Morgan Basye. Kenzie George, Kendal DeMarco, Joy Mills, Heather Baldwin, Caitlyn McConn, Dr. Kelley Wamsley, and Dr. John Boney. I would have been unable to complete my research without their many, many days of help. I would like to give a special thanks to my mother Virginia Lamp. I will never be able to thank her enough for all her love and support throughout my entire life; I truly would not be where I am today without her. To finish, I would like to thank my family: Mark Lamp, Melissa and Austin Pitchok, Mike Heilman, Arland and Ruth Ann Lamp, and Richard and Theresa Mankowski. Without all your support and guidance, I would not have been able to accomplish all I have today. 


\section{TABLE OF CONTENTS}

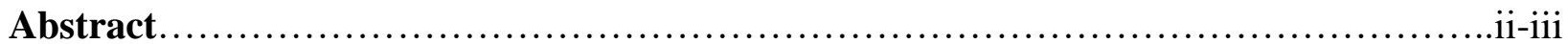

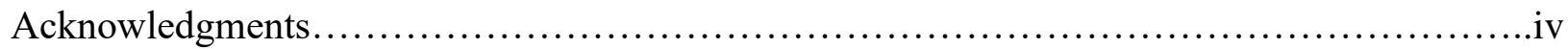

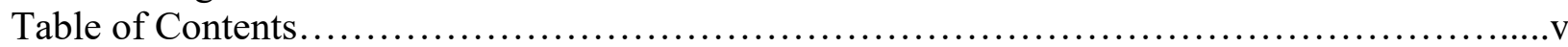

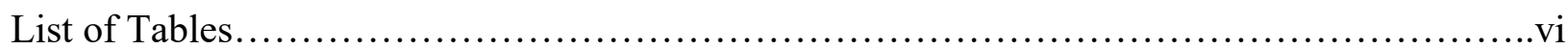

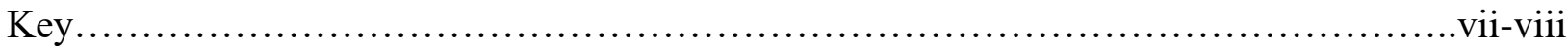

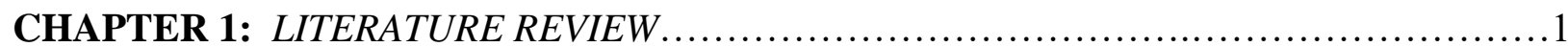

The Poultry Industry.............................................................. 1

Nutrients............................................................................

Feed Additives...................................................................

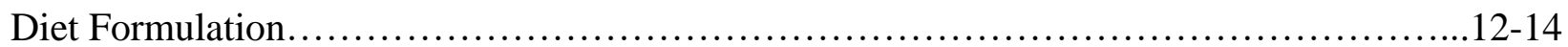

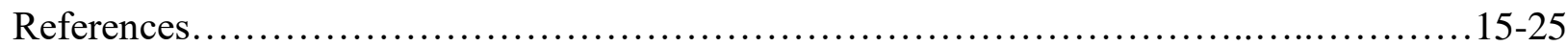

CHAPTER 2: Inorganic feed phosphate type determines mineral digestibility, broiler performance, and bone mineralization ....................................................26

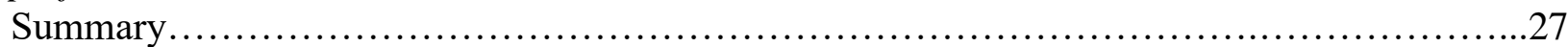

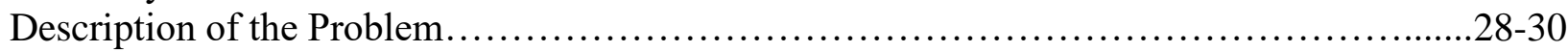

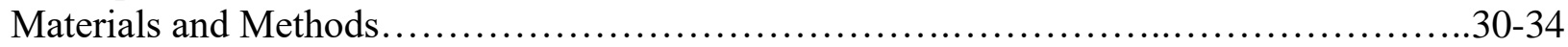

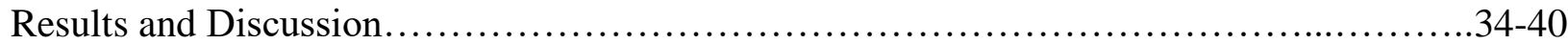

Conclusion and Applications.....................................................40-41

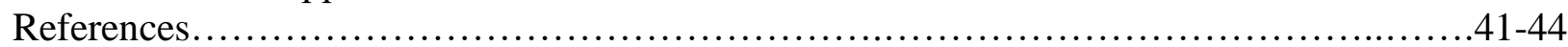

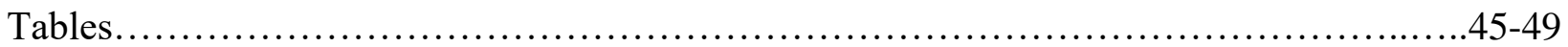

CHAPTER 3: In vitro phytase activity post steam conditioning and pelleting may not consistently correlate with in vivo measurements among commercial phytases..................50

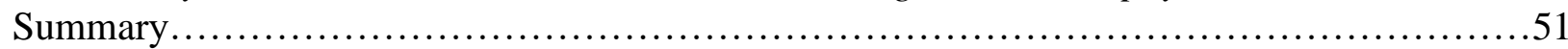

Description of the Problem...........................................................52-54

Materials and Methods.................................................................

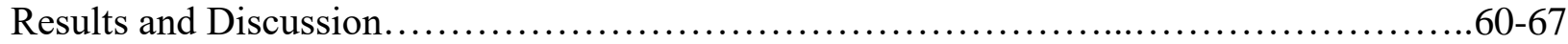

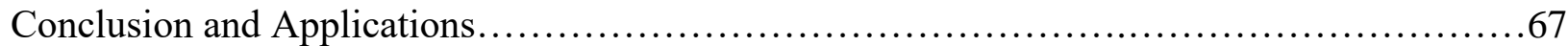

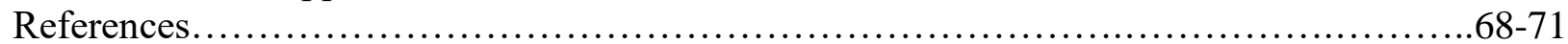

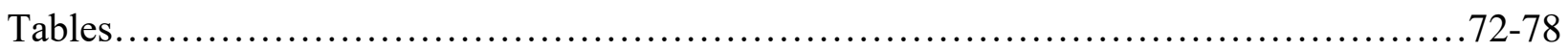

CHAPTER 4: Energy releasing efficacy of graded levels of a commercial microbial phytase..79

Summary........................................................................... 80

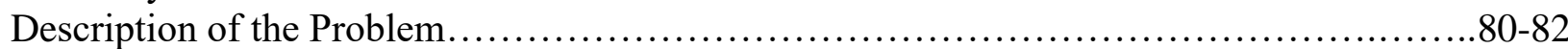

Materials and Methods.............................................................. $82-85$

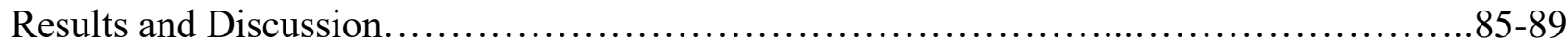

Conclusion and Applications...................................................... 89-90

References........................................................................... 90-93

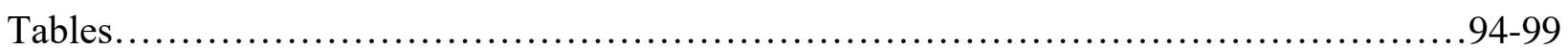

Curriculum Vitae.............................................................100-106 


\section{LIST OF TABLES}

\section{CHAPTER 2}

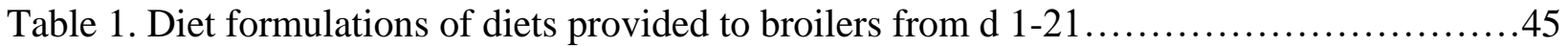

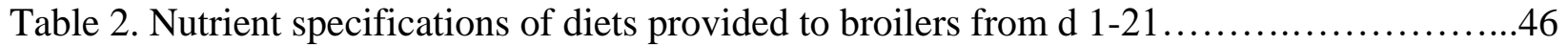

Table 3. Descriptive characteristics of the inorganic feed phosphates and mixtures utilized in experimental diets

Table 4. Growth performance of Ross x Ross 308 male broilers and contrast probability values

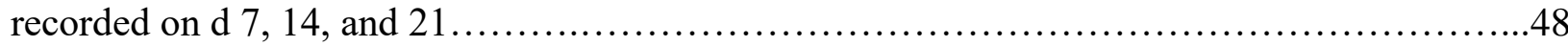

Table 5. Tibia ash and phosphorus and calcium digestibility analysis recorded on $\mathrm{d} 21 \ldots \ldots \ldots .49$

\section{CHAPTER 3}

Table 1. Diet composition and nutrient specifications of the positive and negative control diets provided during the trial........................................................ 72

Table 2. Calculated and analyzed nutrients of diets provided to broilers from $\mathrm{d} 1-21 \ldots \ldots \ldots \ldots . . .73$ Table 3. Descriptive pellet quality, crumble particle size, moisture analysis, and in vitro phytase recovery data collected post-manufacture .74

Table 4. Performance data obtained from 14 and 21-day old broilers.

$.75-76$

Table 5. Tibia ash and plasma myo-inositol concentration data obtained from 21-day old broilers

Table 6. Pearson correlation coefficients (r; above) and probability values (below) of in vitro phytase activity (FTU/kg) correlated to performance, tibia mineralization, and plasma myoinositol concentration variables analyzed categorically.

Table 7. Pearson correlation coefficients (r; above) and probability values (below) of in vitro phytase activity (FTU/kg) correlated to performance, tibia mineralization, and plasma myoinositol concentration variables analyzed using replicated data.

\section{CHAPTER 4}

Table 1. Diet composition and nutrient specifications of the negative control diets provided during the trial .................................................................... 94

Table 2 . Analyzed nutrients and descriptive in vitro phytase activity of diets provided to broilers from d1-21...

Table 3. Performance data obtained from 7 and 14-day old broilers .96-97

Table 4. Performance data and AMEn obtained from 21-day old broilers 


\section{CHAPTER 1}

1. Calcium $-\mathrm{Ca}$

2. Phosphorus $-\mathrm{P}$

3. Inorganic feed phosphate - IFP

4. Negative control - NC

5. Dicalcium phosphate - DCP

6. Monocalcium phosphate - MCP

7. Monodicalcium phosphate - MDP

8. Defluorinated phosphate - DFP

9. Feed intake - FI

10. Non-phytate phosphorus - nPP

\section{CHAPTER 2}

1. Phosphorus $-\mathrm{P}$

2. Calcium $-\mathrm{Ca}$

3. Inorganic feed phosphate - IFP

4. Dicalcium phosphate-DCP

5. Monodicalcium phosphate - MDP

6. Monocalcium phosphate - MCP

7. Defluorinated phosphate - DFP

8. Mixture of DCP (60\%), MCP (20\%), and monosodium phosphate (20\%) - DMM

9. Mixture of $\mathrm{MCP}(67 \%)$ and silicon dioxide $\left(\mathrm{SiO}_{2}\right)(33 \%)-\mathrm{MCP}+\mathrm{SiO}_{2}$

10. Fluorine $-\mathrm{F}$

11. Sodium $-\mathrm{Na}$

12. Non-phytate phosphorus - nPP

13. Calculated prececal digestible phosphorus - CPDP

14. Titanium - Ti

15. Feed intake - FI

16. Feed conversion ratio - FCR

17. Live weight gain - LWG

18. Apparent ileal Ca digestibility - AID Ca

19. Apparent ileal $P$ digestibility - AID P

20. Least significant difference - LSD

21. Standard error of the mean - SEM

\section{CHAPTER 3}

1. Phosphorus $-\mathrm{P}$

2. Feed intake - FI

3. Body weight $-\mathrm{BW}$

4. Escherichia coli-E. coli

5. Positive control - PC 
6. Calcium $-\mathrm{Ca}$

7. Non-phytate $\mathrm{P}-\mathrm{nPP}$

8. Negative control - NC

9. California Pellet Mill - CPM

10. Hot pellet temperature - HPT

11. Pellet durability index - PDI

12. modified pellet durability index - MPDI

13. New Holmen Pellet Tester - NHPT

14. Feed conversion ratio - FCR

15. Live weight gain - LWG

16. Buttiauxella phytase expressed in Trichoderma reesei-B Trich

17. E. coli phytase expressed in Pichia pastoris - E Pichia

18. E. coli phytase expressed in Trichoderma reesei-E Trich

19. Least significant difference - LSD

20. Standard error of the mean - SEM

\section{CHAPTER 4}

1. Metabolizable energy - ME

2. Negative control - NC

3. Feed intake - FI

4. Feed conversion ratio - FCR

5. Nitrogen-corrected apparent metabolizable energy - AMEn

6. Phosphorus $-\mathrm{P}$

7. Nitrogen $-\mathrm{N}$

8. Calcium $-\mathrm{Ca}$

9. Titanium $-\mathrm{Ti}$

10. Live weight gain - LWG

11. Gross energy - GE

12. Crude protein $-\mathrm{CP}$

13. Positive control - PC

14. Least significant difference - LSD

15. Standard error of the mean - SEM 


\section{CHAPTER 1: LITERATURE REVIEW}

\section{THE POULTRY INDUSTRY}

The global population is expected to grow to nine billion by 2050 and consumption of animal protein will increase by two-thirds (Delgado et al., 1999; Foresight. 2011). According to the Food and Agriculture Organization of the United Nations, world per capita consumption of poultry meat is estimated to be 38 lbs. by 2030 (Food and Agriculture Organization of the United Nations). The National Chicken Council forecasts that United States per capita consumption of total poultry is $110.1 \mathrm{lbs}$., and broiler meat is forecasted to be $92.7 \mathrm{lbs}$. in 2020 (National Chicken Council). Poultry is the second highest consumed meat in the world and is a convenient, cheap, and healthy protein. (Ritchie and Roser, 2019). Therefore, the poultry industry must continue to thrive to feed the ever-increasing population. This may be accomplished by optimizing feed manufacture, feed formulation, management practices, and bird health.

The greatest cost when rearing poultry is feed and feed manufacture; it is 60 to $70 \%$ the total cost of production (Lilly et al., 2011; Corey et al., 2014; Reese at al., 2017). Consequently, when a nutritionist is formulating a diet, he or she must maximize bird production and minimize feed cost. The nutritionist must take several factors into consideration to do so: ingredient cost, composition, and nutrient availably; and bird age, genotype, productivity, feed intake, and health (Kleyn, 2013). Additionally, the poultry industry has developed several feed additives to improve bird performance and decrease diet cost. Feed additives such as: prebiotics, probiotics, organic acids, essential oils, inorganic feed phosphates, exogenous enzymes, etc. (Shires et al., 2012). Understanding the interaction of all these factors in a bird's diet can help to optimize bird production to provide the ever-increasing population with a cheap source of protein. 


\section{NUTRIENTS}

A nutrient is defined as a substance or ingredient that promotes growth, provides energy, and maintains life (Merriam-Webster.com). Animals have requirements for six classes of nutrients: water, carbohydrates, proteins, lipids, minerals, and vitamins (Kleyn, 2013). Therefore, proper nutrition of an animal requires that a nutritionist understand the interactions between each nutrient and the host.

\section{Minerals}

Minerals are inorganic components that constitute the ash content of feed or live tissue that remains after combustion (Underwood \& Suttle, 1999; Vieira, 2008). The essential minerals of an animal can be divided into two categories based on the concentrations found in an animal's body or amounts added to an animal's diet. Macrominerals exist in the animal at concentrations that exceed 100 ppm and include calcium $(\mathbf{C a})$, phosphorus $(\mathbf{P})$, sodium $(\mathrm{Na})$, potassium $(\mathrm{K})$, chlorine $(\mathrm{Cl})$, magnesium $(\mathrm{Mg})$, and sulfur $(\mathrm{S})$. Microminerals, or trace minerals, are present in concentrations less than $100 \mathrm{ppm}$ and include iron $(\mathrm{Fe})$, iodine $(\mathrm{I})$, zinc $(\mathrm{Zn})$, copper $(\mathrm{Cu})$, manganese (Mn), cobalt (Co), molybdenum (Mo), selenium (Se), chromium $(\mathrm{Cr})$, and fluorine $(\mathrm{F})$, nickel $(\mathrm{Ni})$, tin $(\mathrm{Sn})$, silicon $(\mathrm{Si})$, vanadium $(\mathrm{V})$, and arsenic (As) (Underwood \& Suttle, 1999; Leeson and Summers, 2001; Vieira, 2008; Kleyn, 2013).

Minerals are found throughout the body, support many biological functions, and are known to have one or more catalytic functions in enzyme and hormone systems. (Schaible, 1941). Sodium, $\mathrm{K}, \mathrm{Cl}, \mathrm{Ca}$, and $\mathrm{Mg}$ maintain acid-base balance, osmotic control of water distribution, membrane permeability, and tissue irritability in the body. Calcium, $\mathrm{P}$, and $\mathrm{Mg}$ form structural components of the body such as the skeletal system, while sulfur plays a role in muscle protein synthesis (Underwood \& Suttle, 1999; Leeson and Summers, 2001). 
Minerals are included into an animal's diet either as pure minerals or by the addition of ingredients such as plant or animal by-products. The availability of minerals in plant feed ingredients can vary due to the reaction of the soil, maturity of the plant, climate, and insect damage (Schaible, 1941); however, availability is generally below 30\% (Kleyn, 2013). Absorption of minerals occurs mainly in the jejunum and ileum of the bird and can be affected by $\mathrm{pH}$, carriers, forms of the minerals, and presence of other minerals that can compete for absorption. Also, the mechanism of uptake differs between minerals (Leeson and Summers, 2001; Kleyn, 2013).

Minerals make up a relatively small portion of an animal's diet; however, they are still vital to animal growth and function. The amount of essential minerals added to a diet needs to be monitored carefully; excessive intake of a certain mineral could cause toxicity, and inadequate intake could cause a deficiency. This could ultimately negatively affect physiological functions and create structural disorders in the animal (Underwood \& Suttle, 1999; Leeson and Summers, 2001).

\section{Calcium and Phosphorus}

Calcium and $\mathrm{P}$ are essential minerals for proper broiler growth and are involved in numerous biological processes. These minerals are typically discussed together because they are required early in a bird's life for proper skeletal development and are closely related in metabolism in the bird body (Schaible, 1941; Leeson and Summers, 2001; Adedokun and Adeola, 2013; Kleyn, 2013; Proszkowiec-Weglarz and Angel, 2013). Excessive or deficient amounts of either mineral or both will interfere with the other and can result in reduced bird performance and bone mineralization, which ultimately can lead to rickets and tibial 
dyschondrolplasia (Shafey, 1990; Hurwitz, 1995; Leeson and Summers; Proszkowiec-Weglarz and Angel, 2013; Kleyn, 2013). Therefore, the proper ratio must be followed.

The most abundant mineral found in the body of birds is $\mathrm{Ca}$, and $99 \%$ of it is stored as hydroxyapatite in the bone (Veum, 2010; Kleyn, 2013). In addition, Ca is significant for eggshell formation, blood clotting, enzyme activation, and muscle contraction (Leeson and Summers, 2001; Veum, 2010). Calcium exits in three different forms in the body: in the extracellular matrix as ionized $\mathrm{Ca}, \mathrm{Ca}$ bound to protein, $\mathrm{Ca}$ bound to anions, and hydroxyapatite $\left[\mathrm{Ca}_{10}\left(\mathrm{PO}_{4}\right)_{6}(\mathrm{OH})_{2}\right]$ of the bone in the ratio of 2:1 with $\mathrm{P}$ (Adedokun and Adeola, 2013). A Ca deficiency results in a decreased plasma Ca concentration which leads to an increase in parathyroid hormone release. This hormone release leads to the activation of $1 \alpha$-hydroxylase in the kidney to synthesize active vitamin $\mathrm{D}_{3}\left(1,25(\mathrm{OH})_{2} \mathrm{D}_{3}\right)$. Additionally, parathyroid hormone release stimulates $\mathrm{Ca}$ and $\mathrm{P}$ mobilization from bone. Increased production of vitamin $\mathrm{D}_{3}$ results in increased absorption of $\mathrm{Ca}$ in the small intestine and kidney reabsorption of $\mathrm{Ca}$ (Leeson and Summers, 2001; Proszkowiec-Weglarz and Angel, 2013). Calcium is absorbed across the intestinal wall through active (saturable; transcellular) or passive (unsaturable; paracellular) transport. Active transport occurs primarily in the duodenum and upper jejunum and involves vitamin $\mathrm{D}_{3}$ (Walling, 1977; Pansu et al., 1983). Passive transport of Ca takes place throughout the small intestine and there is still a debate whether vitamin $\mathrm{D}_{3}$ plays a role for this type of transport (Bukley and Bronner, 1980; Bronner et al., 1986; Auchère et al., 1998; Adedokun and Adeola, 2013; Kleyn, 2013; Proszkowiec-Weglarz and Angel, 2013).

In the bird body, $\mathrm{P}$ is the second most abundant mineral. About $80 \%$ of $\mathrm{P}$ is stored as hydroxyapatite in the bone (Veum, 2010; Kleyn, 2013; Adedokun and Adeola, 2013). Additionally, P plays an important role in cellular and membrane function, metabolism of fats 
and carbohydrates, and acid-base balance (Scott et al, 1982; Soares, 1995; Applegate and Angel, 2008; Leeson and Summers, 2001; Singh 2008; Veum, 2010). Much like a Ca deficiency, a P deficiency results in a decreased plasma $\mathrm{P}$ concentration which leads to the synthesis of active vitamin $\mathrm{D}_{3}$ in the kidney and stimulation of $\mathrm{Ca}$ and $\mathrm{P}$ mobilization from bone. Increased production of vitamin $\mathrm{D}_{3}$ results in increased absorption of $\mathrm{P}$ in the small intestine and kidney reabsorption of P (Leeson and Summers, 2001; Proszkowiec-Weglarz and Angel, 2013). Several researchers state that $\mathrm{P}$ is absorbed across the intestinal wall via Na-dependent and $\mathrm{Na}$ independent pathways (Murer and Hildmann, 1981; Hilfiker et al., 1998; Murer et al., 2004; Proszkowiec-Weglarz and Angel. 2013). While others declare that P is absorbed across the intestinal wall through active (saturable; transcellular) transport in the duodenum and upper jejunum and involves vitamin $\mathrm{D}_{3}$ (Pansu et al., 1983; Walling, 1977; Adedokun and Adeola, 2013). Excessive amounts of dietary P may result in additional P excretion which may lead to eutrophication (Sharpley, 1999).

\section{Phytate}

Another common nutrient introduced into the bird body via the diet is phytate, which was first identified in 1855 (Hartig, 1855). Phytate, or myo-inositol hexakisdihydrogen phosphate (IP6), is considered to be the primary storage form of phosphate and inositol in mature seeds (Leeson and Summers, 2001; Cowieson et al., 2011; Sommerfeld et al., 2018). In poultry diets, plant-based ingredients make up a majority of the diet. These ingredients can be a good source of $\mathrm{P}$; however, only about one-third of the $\mathrm{P}$ found in plants can be utilized by non-ruminants (Krieger and Steenbock, 1940; O’Dell et al., 1972; Raboy, 1990, 1997; Summers; 1997; Leeson and Summers, 2001; Applegate and Angel, 2008; Manangi and Coon, 2008). Additionally, age effects the availability of $\mathrm{P}$ in these ingredients. Young birds are not able to dephosphorylate 
phytate as well as older birds. Moreover, phytate will chelate with metal ions such as $\mathrm{Ca}, \mathrm{Cu}, \mathrm{Zn}$, Mn, and Fe making them unavailable to the bird. Because of this, phytate has been deemed an anti-nutrient (Kleyn, 2013).

When studying phytate, several terms often appear in the literature; these terms are associated with the chemical structure of phytate. Phytic acid is composed of a myo-inositol ring, and six orthophosphate groups are attached to this ring by ester bonds. Phosphate groups on positions 1, 3, 4, 5 and 6 are aligning equatorially relative to the myo-inositol nucleus; while, the phosphate group on carbon 2 is aligned axially. Phytic acid is the fully protonated free acid form; whereas, phytate and phytin are often associated with the mixed salts of $\mathrm{Mg}, \mathrm{K}$ and $\mathrm{Ca}$ (Maga, 1983; Lott et al., 2000; Cowieson et al., 2016). In neutral pH, the phosphate groups in the phytate molecule have one or two negatively charged ions. When one phosphate group bonds to a mineral or metal ion, the association is much weaker compared to when two phosphate groups bond to one mineral (Leeson and Summers, 2001). Phytate has also been known to bound nutrients in the ileum such as amino acids and energy in the form of mucins. Therefore, the hydrolysis of phytate may not only release $\mathrm{P}$, but minerals, amino acids, and energy may be released as well (Lantzsch et al., 1998; Ravindran et al., 1999; Sebastian et al., 1996; Shelton and Southern, 2006; Kleyn, 2013).

In an attempt to reduce phytate in a plant-based ingredient, the USDA developed a corn mutation with low phytate P and high available P content (Raboy and Gerbasi, 1996; Raboy, 1997). This corn contained approximately $0.27 \%$ total $\mathrm{P}$, of which $0.17 \%$ was estimated to be available to the bird. In contrast, only about $0.03 \%$ of total P found in "normal" corn is available to the bird (Waldroup et al., 2000). Another method utilized by the poultry industry to meet the $\mathrm{P}$ 
requirement of the bird is the utilization of feed additives such as inorganic feed phosphates (IFP) and phytase.

\section{FEED ADDITIVES}

\section{Inorganic Feed Phosphates}

As mentioned previously, feed ingredients from plant sources are unable to meet the $\mathrm{Ca}$ and $\mathrm{P}$ requirements needed by poultry. Therefore, to meet these requirements, inorganic sources of these minerals can be added to the diet (Gordon and Roland, 1999; Applegate and Angel, 2008; Shastak et al., 2012). Some of the IFPs used commercially include dicalcium phosphate (DCP), monocalcium phosphate (MCP), monodicalcium phosphate (MDP), defluorinated phosphate (DFP), and monosodium phosphate. When phosphoric acid is reacted with lime and sulphuric acid, MCP and hydrated DCP are produced (Kleyn, 2013). Defluorinated phosphate is produced by the reaction of phosphate rock concentrate and phosphoric acid in the presence of soda ash. With further processing, fluorine is removed; the final product is tricalcium phosphate containing low F levels and a relatively high $\mathrm{Na}$ concentration (Lima et al., 1999). Monocalcium phosphate, DCP, and MDP contain various amounts of MCP and DCP (Lima et al., 1999). An IFP is labelled DCP when it contains greater than or equal to $51 \%$ DCP. When an IFP contains less than $80 \%$ MCP but greater than $51 \% \mathrm{MCP}$, it is labelled MDP. For an IFP to be labeled MCP, it must contain greater than 80\% MCP (Yara International, Oslo, Norway).

Along with meeting mineral requirements of the bird, certain IFPs have also been shown to have a positive effect on pellet quality and feed manufacture (Leeson and Summers, 2001; Wamsley et al., 2012). However, IFPs vary in mineral content and P and Ca digestibility; this

variability is due to many factors such as differences in chemical structure, particle size, $\mathrm{pH}$, crystallinity, the production process, source of ingredients used, and concentration of 
contaminating elements (Huyghebaert et al., 1980; Lima et al., 1999; Kleyn, 2013). Inorganic feed phosphates are relatively unavailable to the bird, unless these phosphates are heat-treated. Leeson and Summers (2001) state that the heat-treatment converts the unavailable phosphates to available forms such as $\alpha$ - or $\beta$-tricalcium phosphates. Monocalcium, DCP and DFP are the most common forms of phosphate used today in the poultry industry; each IFP has an available P level of 98\%, 97\%, and 95\%, respectively (Lima et al., 1999; Leeson and Summers, 2001).

Phosphate rock is a nonrenewable resource. Cordell and others (2009) state that current global phosphate reserves may be depleted in 50 - 100 years; therefore, future generations may have trouble obtaining enough of this resource (Abelson, 1999; Shastak and Rodehutscord, 2015). Consequently, alternative $P$ sources should be taken into account.

\section{Phytase}

The most valuable exogenous enzyme in poultry diets is phytase (Bedford et al., 2016); this enzyme is used in commercial broiler diets to improve $\mathrm{P}$ availability, diet cost, and environmental impact (Bedford, 2000; Selle and Ravindran, 2007). Phytase (myo-inositol hexaphosphate phosphohydrolases) catalyzes the hydrolytic cleavage of the phosphoric acid esters of inositol, which release P (Lesson and Summers, 2001). Phytase activity was first reported around 1907 and 1908 (Suzuki et al.,1907; McCollum and Hart. 1908). In 1962, efforts began to develop a commercial phytase, and after much trial and error, research, and advancements in technology, the first phytase was marketed in 1990 to the animal-feed industry (Wodzinski and Ullah, 1996; Selle and Ravindran, 2007; Lei et al., 2013). Since that time, phytase has been extensively researched and many phytase products are now sold commercially. In poultry, phytase activity can be found in the intestinal mucosa, blood, and liver; this endogenous phytase is able to dephosphorylate phytate into inositol and free phosphate (Oshima 
et al., 1964; Birge and Avioli, 1981; Maenz and Classen, 1998). However, exogenous phytases are added to the bird's diet to increase phytase activity and liberate additional phytate in the diet that the bird was unable to endogenously liberate.

Phytases are categorized as either a 3-phytase (EC 3.1.3.8) or a 6-phytase (3.1.3.26). A 3phytase is named as such if initial hydrolysis on the myo-inositol ring takes place at position $\mathrm{C}_{3}$; thus, a 6-phytase would commence at position $\mathrm{C}_{6}$ (Selle and Ravindran, 2007). Additionally, there are four classes of phytases: histidine acid phosphatases (HAPs; the first and most extensively studied group), $\beta$-propeller phosphatases (BPPs), purple acid phosphatases (PAPs), and protein tyrosine phosphatases (PTPs). All four of these phytases dephosphorylate phytate; however, their catalytic mechanisms and the chemical means to complete the task differ (Lei et al., 2013). During hydrolysis of phytate, stepwise dephosphorylation reactions generate a series of lower myo-inositol phosphate esters $\left(\mathrm{IP}_{6}, \mathrm{IP}_{5}, \mathrm{IP}_{4}, \mathrm{IP}_{3}, \mathrm{IP}_{2}, \mathrm{IP}_{1}\right)$ and a myo-inositol ring (Cowieson et al., 2011; Sommerfeld et al., 2018). However, it is not likely that phytate undergoes a complete dephosphorylation; the axial $\mathrm{P}$ residue at the $\mathrm{C}_{2}$ position is resistant to hydrolysis. The end product of phytate hydrolysis is likely myo-inositol monophosphate and five inorganic P moieties (Wodzinski and Ullah, 1996; Selle and Ravindran, 2007; Cowieson et al., 2013).

Phytase activity is expressed as FTU per unit of feed (Lesson and Summers, 2001). One phytase unit (FTU) is defined as the amount of enzyme required to release $1 \mu \mathrm{mol}$ of inorganic phosphate per minute from a $5.1 \mathrm{~m} M$ sodium phytate at $\mathrm{pH} 5.5$ and $37^{\circ} \mathrm{C}$. (Engelen et al., 2001). Other abbreviations are utilized that represent phytase activity: FYT, U, PU, and these activities appear to be determined under similar in vitro conditions. To evaluate the phytase activity, an in vitro phytase analysis must be employed. Methods utilized include the AOAC official method 
(AOAC International, 2000; Method 2000.12), Phytex (Phytex LLC, Portland, ME), Engelen et al. $(1994,2001)$, modifications to these methods, etc. However, the phytase assay has been found to be variable; the relative SD for repeatability and reproducibility have been determined to range from 2.2 to 10.6 and 5.4 to $1.5 \%$, respectively (Gizzi et al., 2008). Producers of phytase have diverse recommendations of inclusion level in poultry diets; this can vary anywhere from 500 to $1,000 \mathrm{FTU} / \mathrm{kg}$. However, for some time now, researchers have been experimenting with super-dosing phytase. Inclusions greater than 1,500 FTU/kg are considered super-dosing (Boney and Moritz, 2017). Nelson and cohorts (1971) were the earliest to report super-dosing effects of an Aspergillus ficuum phytase dosed in feed between 950 and 7,600 FTU/kg. These scientists observed an apparent phytate-P disappearance of 38.9 and $94.4 \%$, respectively (Cowieson et al., 2011). Two scientists supplemented corn-soybean meal diets with 93 FTU/kg and 12,000FTU/kg and observed a quadratic increase in phytate-P disappearance with increasing phytase dose $(0$, $93,187,375,750,1,500,3,000,6,000$, or $12,000 \mathrm{FTU} / \mathrm{kg}$ ) from around $42 \%$ to almost $95 \%$, respectively (Shirley and Edwards, 2003).

Phytases differ in their production, form in feed, and nutrient sparing efficacy. Microbial phytases can have many different proteins of origin: Buttiauxella, Citrobactor, braakii Escherichia coli, etc. These phytases can also be expressed in several different organisms such as Aspergillus niger, Trichoderma reesei fungus Aspergillus oryzae micro-organism, Pichia pastoris, etc. Several commercial companies have been experimenting in transgenic grain enzyme technology to produce corn-expressed phytases. Phytases can be purchased as powder, granulated, or liquid forms, and can be added to poultry diets pre or post pelleting. Certain phytases are coated with a lipid or carbohydrate that encapsulates the phytase to minimize denaturation at high pelleting temperatures (Sulabo et al., 2011). This encapsulation can also be 
beneficial when ingested by the bird; phytases are engineered to hydrolyze phytate at different locations in the gastrointestinal tract.

Phytase can be found in the majority of commercial poultry diets; therefore, effects of feed manufacture must be taken into account. The feed manufacture process involves subjecting mash feed to increased heat, moisture, and pressure which can be detrimental to a mixer-added phytase enzyme (Jongbloed and Kemme, 1990; Thomas et al., 1998). These increased conditions may partially or fully denature the enzyme. The loss of phytase activity post feed manufacture may negatively affect bird performance because diets may become deficient in available $\mathrm{P}$ (Loop et al., 2012). This was observed in a study conducted by Homan et al. (2019) where broiler diets containing three different microbial phytases conditioned at three different temperatures $(82,88$, and $93^{\circ} \mathrm{C}$ ) were evaluated and in vitro phytase activity and in vivo measurements were assessed. The researchers concluded that as conditioning temperature increased, generally, in vitro phytase activity decreased, as well as in vivo broiler performance and tibia mineralization $(\mathrm{P}<0.05)$ (Homan et al., 2019). A study conducted by Wilkinson et al. (2013) examined the effect of four conditioning temperatures $\left(75,80,85\right.$, and $\left.90^{\circ} \mathrm{C}\right)$ on in vitro phytase activity of two microbial phytases and subsequent in vivo measurements. The scientists observed a slight increase in in vitro phytase activity and no difference in $\mathrm{d} 21$ feed intake (FI) and BW gain when conditioning temperature was increased from 75 to $80^{\circ} \mathrm{C}$. When conditioning temperature was increased from 80 to $90^{\circ} \mathrm{C}$, in vitro phytase activity and $\mathrm{d} 21 \mathrm{FI}$ decreased, and no difference in $\mathrm{BW}$ gain was observed $(\mathrm{P}<0.05)$ (Wilkinson et al., 2013).

As mentioned previously, phytate forms chelates with energy in the form of mucins, rendering it unavailable to the bird (Kleyn, 2013). Phytase supplementation would help release this bound energy. Coelho and cohorts (2019) conducted a study examining ME releasing 
efficacy of graded levels of Natuphos E in 28-d old broilers fed a corn, soybean meal, and DDGS diet. Natuphos E was dosed at 0, 250, 500, 750, 1000, 2000, and 3000 FTU/kg. Total tract AME digestibility was determined to be $2865,2918,2944,2957,2984,3048$, and $3151 \mathrm{kcal} / \mathrm{kg}$, respectively $(\mathrm{P}=0.02)$. Their research concluded that phytase released 53, 79, 92, 119, 183, and $286 \mathrm{kcal} / \mathrm{kg}$, respectively $(\mathrm{P}=0.03)$. This type of research will ultimately lead to a more precise matrix for phytase in the case of diet formulation in the poultry industry.

\section{DIET FORMULATION}

To properly formulate a diet, a nutritionist must understand how the bird utilizes each nutrient put into the diet. Schaible (1941) states that the proper balance and quality of nutrients will most efficiently grow a broiler. Additionally, because feed is the number one cost to grow a bird, the nutritionist must formulate on a least cost basis. Fortunately, the diet formulation process has changed throughout the years to help cut feed costs by formulating diets based on what the bird will truly utilize.

Historically, poultry diets were formulated based on the ratio of $\mathrm{Ca}: \mathrm{P}$ (total $\mathrm{Ca}$ and total P) and total amino acids in the diet (Angel, 2017). This method led to overformulation of these nutrients; nutritionists in the past formulated diets with greater "safety margins" because they did not know the exact quantity of each nutrient the bird was able to absorb, digest, and utilize. For example, Waldroup and cohorts (2000) state that because of the demands for adequate skeletal development of the rapidly growing bird and the sensitivity to deficiencies of $\mathrm{P}$, it is necessary to provide an adequate margin of safety for this nutrient in broiler diets. However, these overformulations can become expensive and have a negative impact on the environment (Leeson and Summers, 2001; Viljoen, 2001; Applegate and Angel, 2008; Kleyn, 2013; Veum, 2010). Unutilized P by the bird is excreted into their feces; it is common practice for crop farmers to 
spread poultry manure on their fields. Excessive amounts of $\mathrm{P}$ in manure can leach into nearby bodies of water which ultimately leads to eutrophication (Summers, 1997; Sharpley, 1999).

Today in the US, diets are typically formulated based on total $\mathrm{Ca}$, available $\mathrm{P}$ (nonphytate $\mathbf{P}(\mathbf{n P P})$ ), and digestible amino acids for better utilization of nutrients by the bird. Phosphorus requirements for broilers in the NRC (1994) are expressed in terms of total P and nPP. However, this does not take into account that phytate $\mathrm{P}$ may be partially available, and nPP may not be completely available to the bird (Leske and Coon, 2002). Angel (2017) states that the amounts of nutrients (specifically $\mathrm{Ca}$ and $\mathrm{P}$ ) that can be digested, absorbed, and potentially used for deposition in body tissues as well as for metabolic needs is what is important for the animal. Therefore, it is recommended that the poultry industry move towards using $\mathrm{P}$ and Ca digestibility values of feedstuffs in diet formulations as they have for amino acids (Angel, 2017; Anwar et al., 2018; Zhang and Adeola, 2018).

There are several assays that have been utilized to determine the $\mathrm{P}$ and Ca quality of an ingredient post feeding: bone ash, body weight gain, blood inorganic $\mathrm{P}$ concentration, retention measurements, and prececal mineral digestibility (Shastak et al., 2012; Shastak and Rodehutscord, 2015). However, bone ash, blood inorganic P concentration, and body weight gain assays are only able to provide relative values of $\mathrm{P}$ and $\mathrm{Ca}$ quality; this has limited value for a nutritionist formulating diets (Coon et al., 2002). Quantitative as well as qualitative values of P and Ca digestibility of IFPs can be obtained using prececal mineral digestibility and retention measurements. These data make it possible to formulate diets that are closer in their available $\mathrm{P}$ and Ca content; and will help minimize excess $\mathrm{P}$ and $\mathrm{Ca}$ supplementation (Shastak and Rodehutscord, 2015). The Working Group 2, Nutrition of the European federation of branches of World's Poultry Science Association (2013) recommends using prececal mineral digestibility to 
determine available P; they have created a protocol for scientists to follow to better compare results.

When formulating a diet with IFP, the nutritionists must keep in mind that IFPs vary in mineral content and $\mathrm{P}$ and $\mathrm{Ca}$ digestibility. The variability is due to many factors such as differences in chemical structure, particle size, $\mathrm{pH}$, crystallinity, the production process, source of ingredients used, and concentration of contaminating elements. When formulating a diet with phytase, the nutritionist much keep in mind the other nutrients that will be liberated, other than $\mathrm{P}$, when phytate is hydrolyzed. For example, both $\mathrm{P}$ and $\mathrm{Ca}$ levels need be reduced if phytase is used in diet formulation (Leeson and Summers, 2001). There are a few ways to account for increased P availability when formulating a diet with phytase. Namely, the available P level of ingredients can be increased, the available P level of the diet can be reduced, or the phytase enzyme can be included as an ingredient with specifications for available $\mathrm{P}$ and $\mathrm{Ca}$ (Leeson and Summers, 2001). Leeson and Summers (2001) state that adding 500 units of phytase $/ \mathrm{kg}$ of feed provides about $0.10 \%$ available $\mathrm{P}$ in the diet.

Optimal knowledge on the amounts of nutrients that can be digested, absorbed, and potentially used by the bird is what is needed to produce a cheap and healthy protein source; a nutritionist is feeding nutrients to the bird, not ingredients. The poultry industry's mission is to feed the world; this will be achieved by continual research and evolving practices. 


\section{REFERENCES}

Abelson, P. H. 1999. A potential phosphate crisis. Science 283:2015.

Adedokun, S. A. and O. Adeola. 2013. Calcium and phosphorus digestibility: Metabolic limits. Journal of Applied Poultry Research 22:600-608.

Angel, R. 2017. Rethinking calcium and phosphorus nutrition in poultry: The importance of calcium digestibility. Department of Animal and Avian Sciences, University of Maryland, College Park.

Anwar, M. N., V. Ravindran, P. C. H. Morel, G. Ravindran, and A. J. Cowieson. 2018. Measurement of the true ileal calcium digestibility of some feed ingredients for broiler chickens. An. Feed Sci. and Tech. 237:118-1280.

AOAC International. 2000. Official Methods of Analysis of the AOAC International, 17th ed., Gaithersburg, MD.

Applegate, T. J., and R. Angel. 2008. Phosphorus requirements for poultry. AS-583-W Purdue Univ. Coop. Ext., West Lafayette, IN. Accessed June 4, 2014.

Auchère, D., S. Tardivel, J. C. Gounelle, T. Drueke, and B. Lacour. 1998. Role of transcellular pathway in ileal Ca2+ absorption: stimulation by low-Ca2+ diet. Am. J. Physiol. 275:G951-G956.

Bedford, M. R. 2000. Exogenous enzymes in monogastric nutrition-Their current value and future benefits. Anim. Feed Sci. Technol. 86(1-2):1-13.

Bedford, M. R., C. L. Walk, and H. V. Masey O’Neill. 2016. Assessing measurements in feed enzyme research: Phytase evaluations in broilers. J. Appl. Poult. Res. 25(2):305-314. 
Birge, S. J. and R. C. Avioli. 1981. Intestinal phosphate transport and alkaline phosphatase activity in the chick. American Journal of Physiology (Endocrinology Metabolism). 240: 384-390.

Boney J. W. and J.S. Moritz. 2017. Phytase dose effects in practically formulated diets that vary in ingredient composition on feed manufacturing and broiler performance. Journal of Applied Poultry Research. 26: 273-285.

Bronner, F., D. Pansu, and W. D. Stein. 1986. An analysis of intestinal calcium transport across the rat intestine. Am. J. Physiol. 250:G561-G569.

Buckley, M. and F. Bronner. 1980. Calcium-binding protein biosynthesis in the rat: Regulation by calcium and 1,25-dihydroxyvitamin D3. Arch. Biochem. Biophys. 202:235-241.

Coelho, M., R. Jones, F. Parks. 2019. Energy (ME) and amino acid releasing efficacy of graded levels of 6-phytase, Natuphos E, in 28 day old broilers fed a corn/soy/DDGs diet. Poult. Sci. Vol. 98 (Suppl. 1): 342.

Coon, C., K. Leske, and S. Seo. 2002. The availability of calcium and phosphorus in feedstuffs. Pages 151 - 179 in Poultry Feedstuffs: Supply, Composition and Nutritive Value. J. M. McNab ad K. N. Boorman, ed. CABI Pub, New York, NY.

Cordell, D., J. O. Drangert, and S. White. 2009. The story of phosphorus: Global food security and food for thought. Global Environmental Change. 19: 292-305.

Corey, A. M., K. G. S. Wamsley, T. S. Winowiski, and J. S. Moritz. 2014. Effects of calcium lignosulfonate, mixer-added fat, and feed form on feed manufacture and broiler performance. Journal of Applied Poultry Research. Volume 23: 418-428.

Cowieson, A. J., A. Ptak, P. Maćkowiak, M. Sassek, E. Pruszyńska-Oszmałek, K. Żyła, S. Świątkiewicz, S. Kaczmarek, and D. Józefiak. 2013. The effect of microbial phytase and 
myo-inositol on performance and blood biochemistry of broiler chickens fed wheat/cornbased diets. Poultry Science. 92:2124-2134.

Cowieson, A. J., J. P. Ruckebusch, I. Knap, P. Guggenbuhl, and F. Fru-Nji. 2016. Phytate-free nutrition: A new paradigm in monogastric animal production. Animal Feed Science and Technology. 222:180-189.

Cowieson, A. J., P. Wilcocock, and M. R. Bedford. 2011. Super-dosing effects of phytase in poultry and other monogastrics. World's Poult. Sci. J. 67:225-235.

Delgado, C., M. Rosegrant, H. Steinfeld, S. Ehui, and C. Courbois. 1999. Livestock to 2020: The next food revolution. FAO discussion paper.

Engelen, A. J., F. C. van der Heeft, P. H. G. Randsdorf, and E. L. C. Smit. 1994. Simple and rapid determination of phytase activity. J. AOAC Int. 77:760-764.

Engelen, A. J., F. C. van der Heeft, P. H. G. Randsdorp, W. A. C. Somers, J. Schaefer, and B. J. C. van der Vat. 2001. Determination of phytase activity in feed by a colorimetric enzymatic method: Collaboration interlaboratory study. J. AOAC Int. 84:629-633.

Food and Agriculture Organization of the United Nations. http://www.fao.org/3/y4252e/y4252e05b.htm.

Foresight. 2011. The future of food and farming. Final project report. The Government Office for Science, London.; United Nations Population Division, DESA. https://www.un.org/en/development/desa/population/events/pdf/expert/6/worldpoptotals. pdf; https://news.un.org/en/story/2011/12/398332.

Gizzi, G., P. Thyregod, C. von Holst, G. Bertin, K. Vogel, M. Faurschou-Isaksen, R. Betz, R. Murphy, and B. B. Andersen. 2008. Determination of phytase activity in feed: Interlaboratory study. J. AOAC Int. 91:259-267. 
Gordon, R. W. and D. A. Roland. 1999. Ascertaining In vivo Phosphate Solubilization: Mineral Recovery Techniques and Phosphorus Sources. J. Appl. Poult. Res. 8:48-53.

Hartig, T. 1855. Uber das klebermehl. Botanische Zeitung 13: 881-885.

Hilfiker, H., O. Hattenhauer, M. Traebert, I. Forster, H. Murer, and J. Biber. 1998. Characterization of a murine type II sodium-phosphate cotransporter expressed in mammalian small intestine. Proc. Natl. Acad. Sci. USA 95:14564-14569.

Homan, V. B., J. W. Boney, and J. S. Moritz. 2019. Effects of steam conditioning temperatures on commercial phytases and subsequent broiler performance and tibia mineralization. App. Animal Sci. 35(3):298 - 303.

Hurwitz, S., I. Plavnik, A. Shapiro, E. Wax, H. Talpaz, and A. Bar. 1995. Calcium metabolism and requirements of chickens are affected by growth. J. Nutr. 125:2679-2686.

Huyghebaert, G., G. De Groote, and L. Keppens, 1980. The relative biological availability of phosphorus in feed phosphates for broilers. Ann. Zootec. 29:245-253.

Jongbloed, A. W., and P. A. Kemme. 1990. Effect of pelleting mixed feeds on phytase activity and the apparent absorbility of phosphorus and calcium in pigs. Anim. Feed Sci. Technol. 28:233-242.

Kleyn, R. 2013. Chicken Nutrition: A Guide for Nutritionists and Poultry Professionals. British library press, Leicestershire, London, UK.

Krieger, C. H., and H. Steenbock. 1940. Cereals and rickets. XII. The effect of calcium and vitamin D on the availability of phosphorus. Journal of Nutrition. 20:125.

Lantzsch, H. J., S. E. Scheuermann, and K. H. Menke. 1998. Influence of various phytase sources on the $\mathrm{P}, \mathrm{Ca}$ and $\mathrm{Zn}$ metabolism of young pigs at different dietary $\mathrm{Zn}$ levels. J. Anim. Physiol. Anim. Nutr. (Berl.). 60:146-157. 
Leeson, S. and J. D. Summers. 2001. Nutrition of the Chicken. $4^{\text {th }}$ Edition. University Books. Guelph, Ontario Canada.

Lei, X. G., J. D. Weaver, E. Mullaney, A. H. Ullah, and M. J. Azain. 2013. Phytase, a new life for an "old” enzyme. Annu. Rev. Anim. Biosci. 1:283-309.

Leske, K. and C Coon. 2002. The development of feedstuff retainable phosphorus values for broilers. Poult. Sci. 81:1681-1693.

Lilly, K. G. S., C. K. Gehring, K. R. Beaman, P. J. Turk, M. Sperow, and J. S. Moritz. 2011. Examining the relationships between pellet quality, broiler performance, and bird sex. Journal of Applied Poultry Research. 20:231-239.

Lima, F. R., J. I. Fernandes, E. Oliveira, G. C. Fronzaglia, and H. Kahn. 1999. Laboratory evaluations of feed-grade and agricultural-grade phosphates. Poult. Sci. 78:1717-1728.

Loop, S. A., K. G. S. Lilly, L. K. Shires, C. K. Gehring, K. R. Beaman, M. E. Persia, and J. S. Moritz. 2012. The phytase analytical activity of pelleted diets may not adequately describe efficacy in the bird. J. Appl. Poult. Res. 21:492-501.

Lott, J. N. A., I. Ockenden, V. Raboy, and G. D. Batten. 2000. Phytic acid and phosphorus in crop seeds and fruits: a global estimate. Seed Science Research. 10: 11-33.

Maenz, D. D. and H. L. Classen H. L. 1998. Phytase activity in the small intestinal brush border membrane of the chicken. Poultry Science. 77: 557-563.

Maga, J.A. 1983. Phytate: its occurrence, food interactions, nutritional significance and methods of analysis. J. Agric. Food Chem. 30, 1-9.

Manangi, M. K. and C. N. Coon. 2008. Phytate phosphorus hydrolysis in broilers in response to dietary phytase, calcium, and phosphorus concentrations. Poultry Science. 87: 15771586. 
McCollum, E. V. and E. B. Hart. 1908. On the occurrence of a phytin-splitting enzyme in animal tissues. J. Biol. Chem. 4:497-500.

Merriam-Webster.com Dictionary, Merriam-Webster, https://www.merriamwebster.com/dictionary/nutrient?src=search-dict-box.

Murer, H. and B. Hildmann. 1981. Transcellular transport of calcium and inorganic phosphate in the small intestinal epithelium. Am. J. Physiol. 240:G409-G416.

Murer, H., I. Forster, and J. Biber. 2004. The sodium phosphate cotransporter family SLC34. Pflugers Arch. 447:763-767.

National Chicken Council. https://www.nationalchickencouncil.org/about-theindustry/statistics/per-capita-consumption-of-poultry-and-livestock-1965-to-estimated2012-in-pounds/.

Nelson, T. S., T. R. Shieh, R. J. Wodzinski, and J. H. Ware. 1971. Effect of supplemental phytase on the utilization of phytate phosphorus by chicks. Journal of Nutrition 101: 1289-1294.

NRC. 1994. Nutrient Requirements of Poultry. 9th ed. Natl. Acad. Sci., Washington, D.C.

O’Dell, B. L., A. R. de Boland, and S. R. Koirtyohann. 1972. Distribution of phytate and nutritionally important elements among the morphological components of cereal grains. J. Agric. Food Chem. 20:718-721.

Oshima, M., T. G. Taylor, and A. Williams. 1964. Variations in the concentration of phytic acid in the blood of the domestic fowl. Biochemistry. 92: 42-46.

Pansu, D., C. Bellaton, C. Roche, and F. Bronner. 1983. Duodenal and ileal calcium absorption in the rat and effects of vitamin D. Am. J. Physiol. 244:G695-G700. 
Proszkowiec-Weglarz, M and R. Angel. 2013. Calcium and phosphorus metabolism in broilers: Effect of homeostatic mechanism on calcium and phosphorus digestibility. The Journal of Applied Poultry Research. 22(3):609-627.

Raboy, V. 1990. Biochemistry and genetics of phytic acid synthesis. Pages 55-76 in: Inositol Metabolism in Plants. D. J. Moore, W. Boas, and F. A. Loewus, ed. Wiley-Liss, New York, NY.

Raboy, V. 1997. Accumulation and storage of phosphate and minerals. Pages 441-477 in: Advances in Cellular and Molecular Biology of Plants. Vol. 4. B. A. Larkins and I. K. Vasil, ed. Kluwer Publishers, Dordrecht, The Netherlands.

Raboy, V. and P. Gerbasi. 1996. Genetics of myoinositol phosphate synthesis and accumulation. Pages 257-285 in: Subcellular Biochemistry. Vol. 26. B. B. Biswas and S. Biswas, ed. Plenum Press, New York, NY.

Ravindran, V., S. Cabahug, G. Ravindran, and W. L. Bryden. 1999. Influence of microbial phytase on apparent ileal amino acid digestibility of feedstuffs for broilers. Poult. Sci. 78:699-706.

Reese, D. A., K. L. Foltz, and J. S. Moritz. 2017. Effect of mixing and sampling method on pelleted feed nutrient analysis and diet formulation validation. Journal of Applied Poultry Research. 26:219-225.

Ritchie, H. and M. Roser. 2019. Meat and Dairy Production. Published online at OurWorldInData.org. Retrieved from: 'https://ourworldindata.org/meat-production' [Online Resource]https://ourworldindata.org/meat-production).

Schaible, P. J. 1941. The Minerals in Poultry Nutrition - A Review. Poultry Science. (20)3: 278288. 
Scott, M. L., M. C. Nesheim, and R. J. Young. 1982. Nutrition of the Chicken. 4th ed. M. L. Scott and Associates, Ithaca, NY.

Sebastian, S., S. P. Touchburn, E. R. Chavez, and P. C. Lague. 1996. The effects of supplemental microbial phytase on the performance and utilization of dietary calcium, phosphorus, copper and zinc in broiler chickens fed corn-soybean diets. Poult. Sci., 75:729-736.

Selle, P. H., and V. Ravindran. 2007. Microbial phytase in poultry nutrition. Anim. Feed Sci. Technol. 135:1-41.

Shafey, T. M., M. W. McDonald, and R. A. Pym. 1990. Effects of dietary calcium, available phosphorus and vitamin D on growth rate, food utilization, plasma and bone constituents and calcium and phosphorus retention of commercial broiler strains. Br. Poult. Sci. 31:587-602.

Sharpley, A. 1999. Symposium: Reducing the environmental impact of poultry production: Focus on phosphorus. Poultry Sci. 78:660-673.

Shastak, Y. and M. Rodehutscord. 2015. Recent developments in determination of available phosphorus in poultry. The Journal of Applied Poultry Research. 24:283-292.

Shastak, Y., M. Witzig, K. Hartung, W. Bessei, and M. Rodehutscord. 2012. Comparison and evaluation of bone measurements for the assessment of mineral phosphorus sources in broilers. Poult. Sci. 91: 2210-2220.

Shelton, J. L. and L. L. Southern. 2006. Effects of phytase addition with or without a trace mineral premix on growth performance, bone response variables, and tissue mineral concentrations in commercial broilers. J. Appl. Poult. Res. 15:94-102. 
Shires, L. K., K. G. S. Lilly, S. A. Loop, C. K. Gehring, P. J. Turk, and J. S. Moritz. 2012. Justifying phytogenic feed additive matrix values in conjunction with exogenous feed enzymes. Journal of Applied Poultry Research. 21:39-47.

Shirley, R. B. and H. M. Edwards. 2003. Graded levels of phytase past industry standards improves broiler performance. Poultry Science. 82:671-680.

Singh, P. K. 2008. Significance of phytic acid and supplemental phytase in chicken nutrition: a review. World's Poultry Science Journal. 64(4), 553-580.

Soares, J. H. 1995. Phosphorous bioavailability. Pages 257-294 in Bioavailability of Nutrients for Animals. C. B. Ammerman, D. H. Baker, and A. J. Lewis, ed. Academic Press, New York, NY.

Sommerfeld, V., M. Schollenberger, I. Kühn, and M. Rodehutscord. 2018. Interactive effects of phosphorus, calcium, and phytase supplements on products of phytate degradation in the digestive tract of broiler chickens. Poult. Sci. 97(4):1177-1188.

Sulabo, R. C., C. K. Jones, M. D. Tokach, R. D. Goodband, S. S. Dritz, D. R. Campbell, B. W. Ratliff, J. M. DeRouchey, and J. L. Nelssen. 2011. Factors affecting storage stability of various commercial phytase sources. J. Anim. Sci. 89:4262-4271.

Summers, J. D. 1997. Precision Phosphorus Nutrition. The Journal of Applied Poultry Research. 6:495-500.

Suzuki U, Yoshimura K, Takaishi M. 1907. Über ein enzym 'Phytase' das anhydro-oxymethylen diphosphorsaure' spalter. Tokyo Imper. Univ. Coll. Agric. Bull. 7:503-12.

Thomas, M., T. V. Vliet, and A. F. B. Van Der Poel. 1998. Physical quality of pelleted animal feed 3. Contribution of Feedstuff component. Animal Feed Science and Technology 70: $59-78$. 
Underwood, E. J. and N. F. Suttle. 1999. Mineral Nutrition of Livestock. $3^{\text {rd }}$ Edition. CABI Publishing Series, Edinburgh, Scotland.

Veum, T. L. 2010. Phosphorus and Calcium Utilization and Requirements in Farm Animals. D. M. S. S. Vitti and E. Kebreab, ed. CAB International, Oxfordshire, UK.

Vieira, S. L. 2008. Chelated minerals for poultry. Brazilian Journal of Poultry Science. 10(2):7379.

Viljoen, J. 2001. Utilization of feed phosphates: Fact or confusion? Pages 24-27 in AFMA Matrix. Animal Feed Manufacturers Association, Centurion, South Africa; Cromwell, G.L., 1980 .

Waldroup, P. W., J. H. Kersey, E. A. Saleh, C. A. Fritts, F. Yan, H. L. Stilborn, R. C. Crum, and V. Raboy. 2000. Nonphytate phosphorus requirement and phosphorus excretion of broiler chicks fed diets composed of normal or high available phosphate corn with and without microbial phytase. Poultry Science. 79:1451-1459.

Walling, M. W. 1977. Intestinal Ca and phosphate transport: Differential responses to vitamin D3 metabolites. Am. J. Physiol. 233:E488-E494.

Wamsley, K. G. S., C. K. Gehring, A. Corzo, E. A. Fontana, and J. S. Moritz. 2012. Effects of inorganic feed phosphate on feed quality and manufacturing efficiency. J. Appl. Poult. Res. 21:823-829.

Wilkinson, S. J., C. L. Walk, M. R. Bedford, and A. J. Cowieson. 2013. Influence of conditioning temperature on the postpellet recovery and efficacy of 2 microbial phytases for broiler chicks. J. Appl. Poult. Res. 22(2):308-313.

Wodzinski, R. J. and A. H. J. Ullah. 1996. Phytase. Adv. Appl. Microbiol. 42:263-303. 
WPSA (World's Poultry Science Association, Working Group 2: Nutrition of the European federation of branches). 2013. Determination of phosphorus availability in poultry. World's Poult. Sci. J. 69: 687-698.

Zhang, F. and O. Adeola. 2018. True ileal digestibility of calcium in limestone and dicalcium phosphate are additive in diets of broiler chickens. Poult. Sci.0:1-7. 


\title{
CHAPTER 2
}

Inorganic feed phosphate type determines mineral digestibility, broiler performance, and bone mineralization

\author{
A. E. Lamp*, A. Mereu ${ }^{\ddagger}$, I. Ruiz-Ascacibar ${ }^{\ddagger}$, and J. S. Moritz* \\ *Division of Animal and Nutritional Sciences, West Virginia University, Morgantown, \\ West Virginia, 26506 \\ Phone: 304-293-1911
}

Fax: 304-293-2232

¥ Yara Iberian S.A.U., Infanta Mercedes St., E-28020 Madrid, Spain

Corresponding Author: Joe.Moritz@mail.wvu.edu

Primary Audience: Feed Manufactures, Nutritionists, Researches 


\section{SUMMARY}

An experiment was conducted to evaluate early broiler performance, tibia mineralization, and mineral digestibility of broilers fed diets that differed in inorganic feed phosphates (IFP) but that were formulated to be either similar in dietary non-phytate phosphorus (nPP) and calcium to phosphorus ratio (Ca:P), total mineral content, or calculated prececal digestible phosphorus (CPDP). Dicalcium phosphate (DCP), monodicalcium phosphate (MDP), monocalcium phosphate (MCP), and defluorinated phosphate were used in formulations with similar nPP and Ca:P. In addition to these four treatments, a mixture of MCP, monosodium phosphate, and DCP was used to assimilate total mineral content of MDP (DMM). Moreover, a mixture of MCP and silicon dioxide was used to produce a similar CPDP as the DCP diet $\left(\mathrm{MCP}+\mathrm{SiO}_{2}\right)$. The $\mathrm{MCP}+\mathrm{SiO}_{2}$ diet had the lowest IFP inclusion. The study utilized a randomized complete block design with ten replications of ten male broilers fed each of six dietary treatments for 21 days. Linear contrasts were utilized to compare treatments of interest. Birds fed MCP demonstrated increased live weight gain, tibia ash (mg/chick), and mineral digestibility compared to DCP when diets were formulated to similar nPP and Ca:P $(\mathrm{P}<0.05)$. When diets were formulated to similar total mineral content, MDP fed birds had an increase in tibia ash (\%) and mineral digestibility compared to birds fed DMM $(\mathrm{P}<0.05)$. Birds fed $\mathrm{MCP}+\mathrm{SiO}_{2}$ had increased mineral digestibility compared to birds fed DCP when diets were formulated to similar CPDP $(\mathrm{P}<0.05)$. Dietary inclusion and efficacy data suggest that diets formulated using CPDP may optimize feed $\mathrm{P}$ incorporation and utilization.

Key words: inorganic feed phosphate, monocalcium phosphate, dicalcium phosphate, monodicalcium phosphate, defluorinated phosphate, phosphorus digestibility 


\section{DESCRIPTION OF PROBLEM}

Phosphorus $(\mathbf{P})$ and calcium $(\mathbf{C a})$ are essential minerals for proper growth performance and bone mineralization in poultry. In addition, Ca is significant for eggshell formation, blood clotting, enzyme activation, and muscle contraction; while $\mathrm{P}$ plays an important role in cellular and membrane function, metabolism of fats and carbohydrates, and acid-base balance (Applegate and Angel, 2008; Kleyn, 2013; Leeson and Summers, 2001; Veum, 2010). Although Ca and P are present in plant origin feed stuffs (Viljoen, 2001; Nelson et al., 1968; Huyghebaert et al., 1980; Adedokun and Adeola, 2013), inorganic feed phosphates (IFP) are still needed to cover mineral requirements in diets for poultry (Applegate and Angel, 2008; Gordon and Roland, 1999; Shastak et al., 2012). Some of the IFPs used commercially include dicalcium phosphate (DCP), monocalcium phosphate (MCP), monodicalcium phosphate (MDP), defluorinated phosphate (DFP), and monosodium phosphate.

The production of these IFPs vary between products. When phosphoric acid is reacted with lime and sulphuric acid, MCP and hydrated DCP are produced (Kleyn, 2013). Defluorinated phosphate is produced by the reaction of phosphate rock concentrate and phosphoric acid in the presence of sodium carbonate. With further processing, fluorine $(\mathbf{F})$ is removed; the final product is tricalcium phosphate containing low F levels and a relatively high sodium (Na) concentration (Lima et al., 1999). Monocalcium phosphate, DCP, and MDP contain various amounts of MCP and DCP. For a product to be considered DCP, it must contain greater than or equal to $51 \%$ DCP. When an IFP contains less than $80 \%$ MCP but greater than 51\% MCP, it is labelled MDP. For an IFP to be labeled MCP, it must contain greater than $80 \% \mathrm{MCP}$ (Yara International, Oslo, Norway). 
Phosphate rock is a nonrenewable resource used to produce IFPs. Cordel et al. (2009) estimated that global reserves may last for 50-100 years more. Inorganic feed phosphates vary in mineral content and $\mathrm{P}$ and $\mathrm{Ca}$ availability to the animal. This variability is due to many factors such as differences in chemical structure, particle size, $\mathrm{pH}$, crystallinity, the production process, source of ingredients used, and concentration of contaminating elements (Kleyn, 2013; Lima et al.; WPSA, 2013; Huyghebaert et al., 1980). The sustainability of the poultry industry relies on a responsible use of IFPs in diets. The exact knowledge about $\mathrm{P}$ availability in each type of IFP is needed to optimize nutrient use efficiency and avoid extra costs and excessive excretion (Applegate and Angel, 2008; Viljoen, 2001).

Historically, poultry diets were formulated based on the ratio of $\mathrm{Ca}: \mathrm{P}$, which is defined as total $\mathrm{Ca}$ and total $\mathrm{P}$ in the diet. Today in the US, diets are typically formulated based on total $\mathrm{Ca}$ and available $\mathrm{P}$ (non-phytate $\mathrm{P}$ (nPP)) for better utilization of $\mathrm{P}$ by the bird. Phosphorus requirements for broilers in the NRC (1994) are expressed in terms of total P and nPP. However, this does not take into account that phytate $\mathrm{P}$ may be partially available, and nPP may not be completely available to the bird (Leske and Coon, 2002).

Different assays have been classically used to determine the P and Ca availability of an ingredient (Shastak et al., 2012; Shastak and Rodehutscord, 2015). Bone ash, blood inorganic P concentration, and body weight gain assays provide relative values of $\mathrm{P}$ and $\mathrm{Ca}$ availability, which makes the comparison of data from different studies impossible. Therefore, these methods have limited value for feed formulation (Coon et al., 2002). Quantitative values of $\mathrm{P}$ and $\mathrm{Ca}$ digestibility of IFPs can be obtained using retention measurements and prececal mineral digestibility. These data make it possible to formulate diets that closely match $\mathrm{P}$ and $\mathrm{Ca}$ requirements whilst minimizing excess $\mathrm{P}$ and Ca supplementation (Shastak and Rodehutscord, 
2015). The experimental effort to obtain quantitative measurements of $P$ retention is high, and results can be influenced by dietary P intake excess. The Working Group 2, Nutrition, of the European federation of branches of World's Poultry Science Association recommends using prececal mineral digestibility to determine available P (WPSA, 2013). The group has developed a standard protocol for establishing a unique and commonly accepted system to assess this parameter.

The objective of this study was to understand the impact of using different systems to evaluate the potential of an IFP. For this purpose, diets that differed in IFP source, but were similar in either (1) dietary nPP and Ca:P (2) total mineral content or (3) calculated prececal digestible P (CPDP) (according to CVB, 2016) were formulated, and their impact on early broiler performance, tibia mineralization, and mineral digestibility were assessed.

\section{MATERIALS AND METHODS}

\section{Diet Formulation and Dietary Treatments}

Diets were corn and soybean meal based containing 6\% DDGS and were formulated to contain similar calculated nutrient values that were based on commercial (Donohue, 2013) and research guidelines (Tillman and Dozier, 2013) (Tables 1 and 2). However, nPP and Ca levels were below requirements even with phytase inclusion to better demonstrate potential treatment differences on bird performance and mineral digestibility. A total of six dietary treatments were utilized in this experiment. Each treatment contained a different IFP or IFP mixture:

1) dicalcium phosphate (DCP) (Feed Products \& Service Company, St. Louis, MO),

2) monodicalcium phosphate (MDP) (The Mosaic Company, Plymouth, MN),

3) monocalcium phosphate (MCP) (Yara International, Oslo, Norway),

4) defluorinated phosphate (DFP) (Eurochem, Moscow, Russia), 
5) a mixture of DCP (60\%), MCP (20\%), and monosodium phosphate (20\%) formulated to assimilate total mineral content of MDP (DMM),

6) a mixture of MCP (67\%) and silicon dioxide ( $\left.\mathbf{S i O}_{2}\right)(33 \%)$ formulated to contain similar CPDP as the DCP (MCP+SiO2).

Five of the diets (DCP, MDP, MCP, DFP, DMM) were formulated to contain $0.22 \% \mathrm{nPP}$ and $0.70 \% \mathrm{Ca}$, with a $1.4: 1 \mathrm{Ca}: \mathrm{P}$. The $\mathrm{MCP}+\mathrm{SiO}_{2}$ diet had the lowest IFP content and lower nPP $(0.20 \%)$ and $\mathrm{Ca}(0.66 \%)$ values compared to the other five treatments (Tables 1 and 2$)$. The $\mathrm{MCP}+\mathrm{SiO}_{2}$ diet was formulated this way to be similar in CPDP as determined for DCP: Dicalcium phosphate is included into the diet at $0.5 \%$ which is $5 \mathrm{~g}$ of IFP in a $1 \mathrm{~kg}$ batch of feed. The $\mathrm{P}$ content of DCP is $18.5 \%$; therefore, $0.93 \mathrm{~g}$ of $\mathrm{P}$ is added to the diet with the addition of DCP. The standard digestibility coefficient obtained from the CVB (2016) for DCP is 55\%, meaning that the digestible P supplied through DCP corresponds to $0.5 \mathrm{~g} / \mathrm{kg}(0.93 \mathrm{~g} \mathrm{x} 55 \%)$ (Table 2).

Titanium (Ti) dioxide was utilized as an indigestible marker for mineral digestibility determination, and all diets were top dressed with 1,000 FTU/kg of phytase (Quantum Blue, AB Vista, Marlborough, Wiltshire). Silicon dioxide was used as a non-nutritive additive and potential pellet die scouring agent in the $\mathrm{MCP}+\mathrm{SiO}_{2}$ diet.

\section{Feed Manufacture and Inorganic Feed Phosphates}

All feed was manufactured at the West Virginia University pilot feed mill. All diets were mixed for 10 minutes dry and 10 minutes post soybean oil addition. Multiple samples of each treatment were collected, pooled, and sent to commercial laboratories for nutrient, Ti (NP Analytical Laboratories, St. Louis, MO; AOAC International, 2000; Method 968.08, 984.27, 
935.13, 985.35, 975.03, 990.08, and 993.14), and phytase analysis (Eurofins Nutrition Analysis Center, Des Moines, IA) (Table 2). All feed was provided to birds as mash.

The DCP product utilized in this study contained greater than $85 \%$ calcium bis (dihydrogen orthophosphate) (Feed Products \& Service Company, St. Louis, MO). The MDP product was composed of 40-60\% MCP monohydrate and 25-40\% DCP dihydrate (The Mosaic Company, Plymouth, MN). The MCP product contained greater than or equal to $80 \%$, but less than $90 \%$ calcium bis (dihydrogen orthophosphate) monohydrate (Yara International, Oslo, Norway). The inclusion rates of MCP and DCP in each product are based on manufactures' statements. Individual IFPs were analyzed for P, Ca, and Na (NP Analytical Laboratories, St. Louis, MO) (Table 3).

\section{Live Bird Performance}

A total of six hundred 1-day-old male Ross x Ross 308 (Aviagen, Inc., Huntsville, AL) chicks were obtained from a commercial hatchery (Longeneckers Hatchery, Elizabethtown, PA). On d 1, chicks were individually weighed and allotted into 10 weight groups. One bird from each weight group was placed in one of 60 raised wire cages to create the experimental unit. Each of the six dietary treatments was randomly assigned to a pen within block. A block consisted of six adjacent cages, and there were 10 blocks or replications per treatment. Housing, lighting, and temperature conditions were similar to methodologies described by Lamp et al. (2015). Feed and water were provided for ad libitum consumption. On d 21, birds were exposed to $6 \mathrm{~h}$ dark and then allowed to consume feed for $6 \mathrm{~h}$ to ensure that digesta was present in the digestive tract to perform ileal collection and mineral digestibility measurements. The study period was a total of

21 days, and performance measurements were taken on d 7, 14, and 21. Measured variables associated with performance included: d 21 ending bird weight, pen feed intake (FI), mortality 
corrected FCR, bird live weight gain (LWG), and pen percent mortality. All animals were reared according to protocols approved by West Virginia University Animal Care and Use Committee. Bone Mineralization and Mineral Digestibility

On d 21, all birds were euthanized via cervical dislocation. The left tibia was excised and used to determine dry-defatted tibia ash $\%$ and $\mathrm{mg} / \mathrm{chick}$. Excised tibiae were placed in a freezer until tibia ash analysis began. Tibiae were placed in a drying oven at $105^{\circ} \mathrm{C}$ for 48 hours. Once dried, tibiae were wrapped in filter paper and placed in a Soxhlet apparatus and refluxed with petroleum ether for 16 hours. Following fat extraction, the tibiae were allowed to dry. Tibiae were then removed from the filter paper, weighed, and placed in an ashing oven at $600^{\circ} \mathrm{C}$ for 18 hours. The inorganic matter remaining was weighed, and ash content was determined (Boney and Moritz, 2017).

Five birds from each pen were randomly selected to determine apparent ileal $\mathrm{Ca}$ digestibility (AID Ca) coefficient and apparent ileal P digestibility (AID P) coefficient. The ileum (defined as the portion of the small intestine extending from the Meckel's diverticulum to the ileal-cecal junction) was excised from each bird (Ravindran et al., 1999). This section was cut in half and the lower section was used for collection. The lower ileum was gently flushed with distilled water, and the digesta washing was collected. The collected digesta was pooled per pen and lyophilized at $-40^{\circ} \mathrm{C}$ until dry (Evans et al., 2015). Digesta samples were analyzed for Ti, Ca, and P contents (NP Analytical Laboratories, St. Louis, MO).

Apparent ileal nutrient ( $\mathrm{Ca}$ and $\mathrm{P}$ ) digestibility coefficients were calculated according to Adedokun and cohorts (2015).

AID Ca/AID P coefficient $(\%)=\left[1-\left(\frac{\text { Ti }_{\text {Diet }}}{\text { Ti }_{\text {Digesta }}}\right) x\left(\frac{\text { Nutrient }_{\text {Digesta }}}{\text { Nutrient }_{\text {Diet }}}\right)\right] * 100$ 
The digestible $\mathrm{Ca}$ and $\mathrm{P}$ concentrations of the diet were calculated using the following equation:

Digestible P/digestible Ca concentration $(\%)=$ $\left(\frac{\text { AID nutrient }(\%)}{100}\right) \times$ Nutrient ${ }_{\text {Diet }}(\%)$

Where $\mathrm{Ti}_{\text {Digesta }}$ and $\mathrm{Ti}_{\text {Diet }}$ are the analyzed concentrations of $\mathrm{Ti}(\%)$ in the digesta and diets, respectively, and Nutrient Digesta and Nutrient Diet are the analyzed concentrations of Ca or P in the digesta and diets, respectively.

\section{Statistical Analysis}

A randomized complete block design was utilized with one pen of 10 broilers as the experimental unit. Data were analyzed using GLM procedure of SAS (SAS Institute, 2013) considering cage as the experimental unit for all variables studied, and pen location within the room was used as blocking criterion. Significance was set at $\mathrm{P}<0.05$ and tendency at $\mathrm{P}<0.10$. Differences among treatments were determined using the Fisher's LSD test. Linear contrasts were used to compare diets of interest that were formulated to be either similar in:

1) Dietary nPP and Ca:P (DCP vs. MCP).

2) Total mineral content (MDP vs. DMM).

3) Calculated prececal digestible $\mathrm{P}$ ( $\mathrm{DCP}$ vs. $\mathrm{MCP}+\mathrm{SiO}_{2}$ ).

\section{RESULTS AND DISCUSSION}

\section{Realized Diet Composition and Inorganic Feed Phosphates}

Overall Comparison. The analyzed nutrients of the experimental diets are shown in Table 2. Five of the diets (DCP, MDP, MCP, DFP, DMM) were formulated to $0.22 \% \mathrm{nPP}$, $0.70 \% \mathrm{Ca}, 0.49 \% \mathrm{P}$, and $20 \% \mathrm{CP}$. Analyzed values of the five diets ranged in each nutrient: nPP (0.24-0.28\%), $\mathrm{Ca}(0.63-0.75 \%), \mathrm{P}(0.47-0.51 \%)$, and $\mathrm{CP}(17.9-18.7 \%)$. The $\mathrm{MCP}+\mathrm{SiO}_{2}$ 
diet was formulated to $0.20 \% \mathrm{nPP}, 0.66 \% \mathrm{Ca}, 0.46 \% \mathrm{P}$, and $20 \% \mathrm{CP}$. Analyzed values of the $\mathrm{MCP}+\mathrm{SiO}_{2}$ diet are $0.23 \% \mathrm{nPP}, 0.69 \% \mathrm{Ca}, 0.47 \% \mathrm{P}$, and $17.5 \% \mathrm{CP}$. Phytase activity analysis performed on complete diets ranged from 530 - 1300 FTU/kg (Table 2). The target phytase activity for each diet was $1000 \mathrm{FTU} / \mathrm{kg}$.

The analyzed $\mathrm{P}$ and $\mathrm{Ca}$ values of the IFP products were similar to the calculated values (Table 3). The MCP product contained the highest $\mathrm{P}$ compared to the other products. The DFP product had the highest $\mathrm{Ca}$ and $\mathrm{Na}$ values among all products. The $\mathrm{MCP}+\mathrm{SiO}_{2}$ product had the lowest $\mathrm{P}$ and $\mathrm{Ca}$ values compared to all other products.

Similar dietary nPP and Ca:P (DCP vs. MCP). The MCP diet contained higher $\mathrm{nPP}, \mathrm{P}$, and Ca but lower CP compared to the DCP diet. The MCP product contained lower Ca and higher $\mathrm{P}$ compared to the DCP product. Due to the greater P content and the greater AID P coefficient of MCP when compared to DCP, the needed inclusion level of DCP was $22 \%$ higher compared to the MCP product when diets were formulated to similar nPP and Ca:P (Table 1).

Similar total mineral content (MDP vs. DMM). The MDP diet had a slightly higher CP, $\mathrm{P}$, and nPP content compared to the DMM diet. The MDP product had lower P content and higher analyzed Ca content compared to the DMM IFP mixture.

Similar calculated prececal digestible P (DCP vs. $\left.\mathrm{MCP}+\mathrm{SiO}_{2}\right)$. The DCP diet had higher $\mathrm{CP}$ and nPP but lower $\mathrm{Ca}$ compared to the $\mathrm{MCP}+\mathrm{SiO}_{2}$ diet. The $\mathrm{DCP}$ product contained higher $\mathrm{P}$ and $\mathrm{Ca}$ than the $\mathrm{MCP}+\mathrm{SiO}_{2}$ product. When diets were formulated to similar CPDP, the DCP product had a $67 \%$ higher inclusion in the diet compared to the $\mathrm{MCP}$ in the $\mathrm{MCP}+\mathrm{SiO}_{2}$ diet (Table 1).

\section{Overall Comparison}


Live Bird Performance. The overall comparison among treatments indicated that birds fed MCP had the highest ending bird weight on d 14, followed by MDP, DMM, DFP, DCP, and $\mathrm{MCP}+\mathrm{SiO}_{2}$ fed birds $(\mathrm{P}=0.0460)$ (Table 4). However, no significant differences were found for bird LWG or FCR with the overall comparison. Bikker and cohorts (2016) similarly reported that d 27 ending bird weight was numerically highest when birds were fed an MCP diet, followed by MDP, DCP, and DFP being intermediate, and birds fed the basal diet had the lowest ending bird weight ( $\mathrm{P}<0.001)$. Bikker et al. (2016) sought to determine the prececal $\mathrm{P}$ digestibility of various IFPs at marginal levels of P supply. Bikker's study utilized a basal diet and four additional diets containing either MCP (0.88\% inclusion), MDP (0.92\%), DCP (1.11\%), or DFP (1.07\%). The five diets had a Ca:P of 1.4:1 and a nPP content of $0.28 \%$. However, in the current study, no weight differences were apparent in the overall comparison at $\mathrm{d} 21$. Percent mortality was not significant at any time period $(\mathrm{P}>0.05)$ and did not exceed $5 \%$ for any treatment.

Bone Mineralization. The overall comparison among treatments indicated that tibia ash (\%) increased for birds fed either MCP or MDP compared to birds fed DCP or DFP when diets were formulated to similar nPP and Ca:P $(\mathrm{P}=0.0078)$ (Table 5). Birds fed MCP had the highest tibia ash (mg/chick); DMM, MDP, DFP, and $\mathrm{MCP}+\mathrm{SiO}_{2}$ fed birds were intermediate, and birds provided DCP had the lowest tibia ash (mg/chick) $(\mathrm{P}=0.0026)$.

Mineral Digestibility. The overall comparison among treatments indicated that MDP and DFP fed birds had the highest AID Ca coefficient; $\mathrm{MCP}+\mathrm{SiO}_{2}, \mathrm{DMM}$, and $\mathrm{MCP}$ fed birds were intermediate, and DCP fed birds had the lowest AID Ca coefficient $(\mathrm{P}<0.0001)$ (Table 5). Birds fed MDP and $\mathrm{MCP}+\mathrm{SiO}_{2}$ had the highest AID P coefficient, followed by DMM, MCP, and DFP fed birds being intermediate, and birds provided DCP had the lowest AID P coefficient $(\mathrm{P}<$ 0.0001). Results reported by Bikker et al. (2016) do not agree, stating that birds fed MCP and 
MDP had the highest prececal P digestibility; birds fed the basal diet were comparable to birds provided MDP, and birds fed DCP and DFP had the lowest prececal P digestibility $(\mathrm{P}<0.001)$. Birds fed the basal diet, MCP, and MDP had the highest prececal Ca digestibility; DCP fed birds were comparable to MDP fed birds, and birds provided DFP had the lowest prececal Ca digestibility (P < 0.001) (Bikker et al., 2016). Their study utilized 4 suppliers of monohydrated MCP, 3 suppliers of MDP, and 3 suppliers of DCP; this could explain the difference in mineral digestibility results between the two studies. In the current study, the MDP diet had the highest digestible $\mathrm{Ca}$ and $\mathrm{P}$ concentrations, followed by the DFP, $\mathrm{DMM}, \mathrm{MCP}+\mathrm{SiO}_{2}$, and $\mathrm{MCP}$ diets being intermediate, and the $\mathrm{DCP}$ diet had the lowest digestible $\mathrm{Ca}$ and $\mathrm{P}$ concentrations $(\mathrm{P}<$ $0.0001)$.

\section{Similar dietary $n P P$ and Ca:P (DCP vs. MCP)}

Live Bird Performance. Ending bird weight, LWG, and FI on d 7 and 14 demonstrated an increase for birds fed MCP compared to birds fed DCP $(\mathrm{P}<0.05)$ (Table 4). On d 21, MCP fed birds had an increased ending bird weight $(\mathrm{P}=0.0022)$ and LWG $(\mathrm{P}=0.0021)$, as well as a decreased FCR $(\mathrm{P}=0.0461)$ compared to DCP fed birds. Bikker and coauthors $(2016)$ also reported that birds had increased d 27 ending bird weight, average daily gain, and average daily FI when provided a diet with MCP compared to birds fed a diet formulated to similar nPP and Ca:P with DCP. According to the CVB (2016) and results of the current study, MCP has a higher $\mathrm{P}$ digestibility and digestible $\mathrm{P}$ content than DCP which potentially caused birds provided diets with MCP to have increased skeletal growth and greater ending bird weight and LWG. Despite, the DCP diet had the highest phytase activity and still was not able to compensate.

Bone Mineralization. Birds fed MCP had increased tibia ash $(\mathrm{mg} / \mathrm{chick})(\mathrm{P}=0.0046)$ but not tibia ash $(\%)(\mathrm{P}>0.05)$ compared to birds fed DCP (Table 5). The authors speculate that 
MCP fed birds had increased tibia ash (mg/chick) compared to DCP fed birds due to the fact that MCP has a higher P digestibility and digestible P content than DCP (CVB, 2016). Similarity, Nelson and coauthors (1990) reported no differences for tibia ash (\%) when Cobb 500 male broilers were fed diets containing either MCP or DCP formulated to $0.16 \% \mathrm{nPP}$. Furthermore, the tibia ash values in Nelson's study were lower than the ones found in the current study; likely due to a lower nPP content of Nelson's diets (Nelson et al., 1990).

Mineral Digestibility. When diets were formulated to similar nPP and Ca:P, birds fed MCP had an increased AID Ca coefficient $(\mathrm{P}=0.0045)$, AID P coefficient $(\mathrm{P}<0.0001)$, digestible $\mathrm{Ca}$ concentration $(P=0.0002)$, and digestible $P$ concentration $(P<0.0001)$ compared to birds fed DCP (Table 5). Bikker and others (2016) also reported that birds had increased prececal Ca and P digestibility when they were provided a diet with a $0.88 \%$ inclusion of MCP compared to birds fed a diet with a $1.11 \%$ inclusion of DCP. However, results by Anwar and cohorts (2018) disagree with the current findings. They reported that $24 \mathrm{~d}$ old male Ross 308 broilers fed semipurified diets had similar apparent ileal Ca digestibility when fed a diet with either 4.6\% DCP or 5.77\% MCP $(\mathrm{P}>0.05)$. The basal diet that contained DCP had a Ca:P of 1.11:1 and nPP of 0.81\%, while the diet containing MCP had a Ca:P of 0.79:1 and nPP of 1.29\% (Anwar et al., 2018).

\section{Similar total mineral content (MDP vs. DMM)}

Live Bird Performance: Diets formulated to have similar total mineral content were similar in all performance measurements $(\mathrm{P}>0.05)$ (Table 4). The MDP and DMM diets had similar CPDP ( $0.7 \mathrm{~g})$; therefore, birds provided these diets were expected to have similar performance metrics. 
Bone Mineralization. Tibia ash (\%) demonstrated an increase for birds fed MDP compared to birds fed DMM when diets were formulated to similar total mineral content $(\mathrm{P}=0.0093)$ (Table 5). Results mentioned later in this paper show that the MDP diet had a higher digestible $\mathrm{Ca}$ and $\mathrm{P}$ concentration $(\mathrm{P}<0.05)$ than the $\mathrm{DMM}$ diet which could have led to the increase in tibia ash.

Mineral Digestibility. Birds fed MDP had increased AID Ca coefficient $(\mathrm{P}=0.0074)$, digestible $\mathrm{Ca}$ concentration $(\mathrm{P}=0.0054)$, and digestible $\mathrm{P}$ concentration $(\mathrm{P}=0.0321)$ compared to birds fed DMM when diets were formulated to similar total mineral content. When an IFP contains less than $80 \%$ MCP but greater than $51 \%$ MCP, it is considered MDP (Yara International, Oslo, Norway). The MDP product was composed of 40-60\% MCP monohydrate and 25-40\% DCP dihydrate (The Mosaic Company, Plymouth, MN). The DMM product contained $20 \% \mathrm{MCP}$ and $60 \% \mathrm{DCP}$. Therefore, the MDP product potentially contained more MCP than the DMM product, causing the MDP product to have increased mineral digestibility compared to the DMM product. As previously mentioned, $\mathrm{MCP}$ has an increased $\mathrm{P}$ digestibility and digestible $\mathrm{P}$ content compared to DCP (CVB, 2016).

\section{Calculated prececal digestible $\mathrm{P}\left(\mathrm{DCP} v \mathrm{MS} . \mathrm{MCP}+\mathrm{SiO}_{2}\right)$}

Live Bird Performance. Diets formulated to have similar CPDP were similar in all performance measurements $(\mathrm{P}>0.05)$ (Table 4). The $\mathrm{DCP}$ and $\mathrm{MCP}+\mathrm{SiO}_{2}$ products had similar CPDP (0.5 g); therefore, birds provided these diets were expected to have similar performance metrics.

Bone Mineralization. No significant differences in bone mineralization were found when diets were formulated to similar CPDP $(\mathrm{P}>0.05)$ (Table 5). However, results of the digestible $\mathrm{Ca}$ and $\mathrm{P}$ concentration of each diet would not agree with the results found for bone 
mineralization; the $\mathrm{MCP}+\mathrm{SiO}_{2}$ had increased digestible $\mathrm{Ca}$ and $\mathrm{P}$ concentrations compared to the DCP diet $(\mathrm{P}<0.05)$. The phytase activities of the two diets could lead to an explanation of no differences observed in bone mineralization. The DCP diet had a phytase activity of 1300 FTU/kg, while the $\mathrm{MCP}+\mathrm{SiO}_{2}$ diet had a phytase activity of $530 \mathrm{FTU} / \mathrm{kg}$.

Mineral Digestibility. Birds fed $\mathrm{MCP}+\mathrm{SiO}_{2}$ had increased AID Ca coefficient $(\mathrm{P}=0.0019)$ and AID P coefficient $(\mathrm{P}<0.0001)$ compared to birds fed DCP when diets were formulated to similar CPDP (Table 5). The authors speculate that the increased AID P coefficient of birds fed $\mathrm{MCP}+\mathrm{SiO}_{2}$ compared to birds fed DCP could be due to the CVB (2016) data underestimating the current studies $\mathrm{P}$ digestibility of the MCP product or overestimating the $\mathrm{P}$ digestibility of the DCP product. However, despite these digestibility differences broiler performance and tibia ash were not affected. As previously stated, IFPs vary in P and Ca digestibility; this variability is due to many factors (Kleyn, 2013; Lima et al., 1999; WPSA, 2013; Huyghebaert et al., 1980). In addition, measurable differences in mineral digestibility may not translate to differences in performance or tibia ash measures. The authors do not imply that similar results would be obtained using different IFP products. Also, pellet manufacture efficiency and pellet quality influences of IFP products should be considered in IFP selection.

\section{CONCLUSION AND APPLICATIONS}

1. Birds fed MCP had increased ending bird weight and LWG at each measurement period, tibia ash (mg/chick), and mineral digestibility compared to birds fed DCP when diets were formulated to similar $\mathrm{nPP}$ and $\mathrm{Ca}: \mathrm{P}$, despite the $\mathrm{DCP}$ product having a $22 \%$ higher dietary inclusion compared to the MCP product. This is explained by the greater digestible $\mathrm{P}$ content in the MCP diet. 
2. When diets were formulated to similar CPDP, birds fed $\mathrm{MCP}+\mathrm{SiO}_{2}$ had increased mineral digestibility compared to birds fed DCP, despite the greater DCP inclusion (67\%, compared to the $\mathrm{MCP}$ in the $\mathrm{MCP}+\mathrm{SiO}_{2}$ diet). As expected, similar CPDP translated to similar broiler performances and tibia mineralization status, showing the importance of a proper evaluation system for $\mathrm{P}$ digestibility.

3. Different IFPs may affect early broiler performance, tibia mineralization, and $\mathrm{Ca}$ and $\mathrm{P}$ digestibility differently despite diets being formulated to similar:

a. nPP and Ca:P

b. Total mineral content

These differences are likely associated with variation in digestible minerals of specific IFPs.

4. Diets formulated using CPDP may lower total P inclusion and optimize feed P utilization.

\section{REFERENCES}

Adedokun, S. A. and O. Adeola. 2013. Calcium and phosphorus digestibility: Metabolic limits. J. Appl. Poult. Res. 22:600-608.

Adedokun, S. A., P. Jaynes, R. L. Payne, and T. J. Applegate. 2015. Standardized Ileal Amino Acid Digestibility of Corn, Corn Distillers' Dried Grains with Solubles, Wheat Middlings, and Bakery By-Products in Broilers and Laying Hens. Poult. Sci. 94:24802487.

Anwar, M. N., V. Ravindran, P. C. H. Morel, G. Ravindran, and A. J. Cowieson. 2018. Measurement of the true ileal calcium digestibility of some feed ingredients for broiler chickens. An. Feed Sci. and Tech. 237:118-1280. 
AOAC International. 2000. Official Methods of Analysis of the AOAC International, 17th ed., Gaithersburg, MD.

Applegate, T. J., and R. Angel. 2008. Phosphorus requirements for poultry. AS-583-W Purdue Univ. Coop. Ext., West Lafayette, IN. Accessed June 4, 2014.

Bikker, P., J. W. Spek, R. A. Van Emous and M. M. Van Krimpen. 2016. Precaecal phosphorus digestibility of inorganic phosphate sources in male broilers. British Poult. Sci. 57:810817.

Boney, J. W. and J. S. Moritz. 2017. Phytase dose effects in practically formulated diets that vary in ingredient composition on feed manufacturing and broiler performance. J. Appl. Poult. Res. 26:273-285.

Coon, C., K. Leske, and S. Seo. 2002. The availability of calcium and phosphorus in feedstuffs. Pages 151 - 179 in Poultry Feedstuffs: Supply, Composition and Nutritive Value. J. M. McNab ad K. N. Boorman, ed. CABI Pub, New York, NY.

Cordell, D., J. O. Drangert, and S. White. 2009. The story of phosphorus: Global food security and food for thought. Global Environmental Change. 19: 292-305.

CVB (Centraal Veevoeder Bureau). 2016. Veevoedertabel (Livestock Feed Table). Central Bureau for Livestock Feeding (CVB). Wageningen, The Netherlands.

Donohue. M. 2013. The Challenges in Feeding Broilers in Times of High and Volatile Feed Ingredient Costs: How to Cover the Costs? 2013 Mid-Atlantic Nutrition Conference proceedings.

Evans, A. M., D.L. Smith, and J.S. Moritz. 2015. Effects of algae incorporation into broiler starter diet formulations on nutrient digestibility and 3 to $21 \mathrm{~d}$ bird performance. J. Appl. Poult. Res. 24:206-214. 
Gordon, R. W. and D. A. Roland. 1999. Ascertaining In vivo Phosphate Solubilization: Mineral Recovery Techniques and Phosphorus Sources. J. Appl. Poult. Res. 8:48-53.

Huyghebaert, G., G. De Groot, and L. Keppens. 1980. The relative biological availability of phosphorus in feed phosphates for broilers. Ann. Zootech, 29(3), 245-263.

Kleyn, R. 2013. Minerals. Pages 69-72 in Chicken Nutrition: A Guide for Nutritionists and Poultry Professionals. British library press, Leicestershire, London, UK.

Lamp, A. E., A. M. Evans, and J. S. Moritz. 2015. The effects of pelleting and glucanase supplementation in hulled barley based diets on feed manufacture, broiler performance, and digesta viscosity. J. Appl. Poult. Res. 24: 295-303.

Leeson, S. and J. D. Summers. 2001. Minerals., Feed Ingredients and Feed Formulation. Pages 341, 500 in Nutrition of the Chicken. $4^{\text {th }}$ Edition. University Books. Guelph, Ontario Canada.

Leske, K. and C Coon. 2002. The development of feedstuff retainable phosphorus values for broilers. Poult. Sci. 81:1681-1693.

Lima, F. R., J. I. Fernandes, E. Oliveira, G. C. Fronzaglia, and H. Kahn. 1999. Laboratory evaluations of feed-grade and agricultural-grade phosphates. Poult. Sci. 78:1717-1728.

Nelson, T. S., L. K. Kirby, and Z. B. Johnson. 1990. The Relative Biological Value of Feed Phosphates for Chicks. Poult. Sci. 69:113-118.

Nelson, T. S., L. W. Ferrara, and N. L. Store. 1968. Phytate Phosphorus Content of Feed Ingredients Derived from Plants. Poult. Sci. 47:1372-1374.

NRC. 1994. Nutrient Requirements of Poultry. 9th ed. Natl. Acad. Sci., Washington, D.C. 
Ravindran, V., L. I. Hew, G. Ravindran, and W. L. Bryden. 1999. A comparison of ileal digesta and excreta analysis for the determination of amino acid digestibility in food ingredients for poultry. Br. Poult. Sci. 40:266-274.

SAS Institute. 2013. The SAS system for Windows 2013. Release 9.3 SAS Inst. Inc., Cary, NC. Shastak, Y. and M. Rodehutscord. 2015. Recent developments in determination of available phosphorus in poultry. J. Appl. Poult. Res. 24:283-292.

Shastak, Y., M. Witzig, K. Hartung, W. Bessei, and M. Rodehutscord. 2012. Comparison and evaluation of bone measurements for the assessment of mineral phosphorus sources in broilers. Poult. Sci. 91: 2210-2220.

Tillman, P. B. and W.A. Dozier. 2013. Current Amino Acid Considerations for Broilers: Requirements, Ratios, Economics for 8 - 14 day broilers. www.thepoultryfederation.com.

Veum, T. L. 2010. Phosphorus and calcium nutrition and metabolism. Pages 94-111 in Phosphorus and Calcium Utilization and Requirements in Farm Animals. D. M. S. S. Vitti and E. Kebreab, ed. CAB International, Oxfordshire, UK.

Viljoen, J. 2001. Utilization of feed phosphates: Fact or confusion? Pages 24-27 in AFMA Matrix. Animal Feed Manufacturers Association, Centurion, South Africa; Cromwell, G.L., 1980.

WPSA (World's Poultry Science Association, Working Group 2: Nutrition of the European federation of branches). 2013. Determination of phosphorus availability in poultry. World's Poult. Sci. J. 69: 687-698. 
Table 1. Diet formulations of diets provided to broilers from d 1-21.

\begin{tabular}{|c|c|c|c|c|c|c|}
\hline Ingredients & DCP & MDP & MCP & DFP & DMM & $\mathrm{MCP}+\mathrm{SiO}_{2}$ \\
\hline \multicolumn{7}{|c|}{ Inclusion (\%) } \\
\hline Corn & 59.22 & 59.22 & 59.22 & 59.46 & 59.22 & 59.18 \\
\hline Soybean Meal (48\%) & 29.17 & 29.17 & 29.17 & 29.17 & 29.17 & 29.18 \\
\hline Corn DDGS & 6.00 & 6.00 & 6.00 & 6.00 & 6.00 & 6.00 \\
\hline Soybean oil & 2.27 & 2.27 & 2.27 & 2.19 & 2.27 & 2.28 \\
\hline DL-Methionine & 0.34 & 0.34 & 0.34 & 0.34 & 0.34 & 0.34 \\
\hline Vitamin Mineral Premix ${ }^{1}$ & 0.25 & 0.25 & 0.25 & 0.25 & 0.25 & 0.25 \\
\hline Sodium Bicarbonate & 0.10 & 0.10 & 0.10 & .010 & 0.10 & 0.10 \\
\hline Lysine & 0.36 & 0.36 & 0.36 & 0.36 & 0.36 & 0.36 \\
\hline Threonine & 0.21 & 0.21 & 0.21 & 0.21 & 0.21 & 0.21 \\
\hline Feed Phosphate & 0.50 & 0.49 & 0.41 & 0.51 & 0.45 & $0.30 \mathrm{MCP}$ \\
\hline Limestone & 1.34 & 1.39 & 1.42 & 1.22 & 1.42 & 1.40 \\
\hline Salt & 0.26 & 0.20 & 0.26 & 0.19 & 0.21 & 0.26 \\
\hline
\end{tabular}

$\mathrm{DCP}=$ dicalcium phosphate, $\mathrm{MDP}=$ monodicalcium phosphate, $\mathrm{MCP}=$ monocalcium phosphate, $\mathrm{DFP}=$ defluorinated phosphate, $\mathrm{DMM}=1 / 5 \mathrm{MCP}, 1 / 5$ monosodium phosphate, $3 / 5$ $\mathrm{DCP}$, and $\mathrm{MCP}+\mathrm{SiO}_{2}=\mathrm{MCP}+\mathrm{SiO}_{2}(67: 33)$.

${ }^{2}$ Vitamin mineral premix (NB3000, Nutrablend, Neosho, MO) supplied the following per $\mathrm{kg}$ of diet: manganese, $0.02 \mathrm{mg}$; zinc, $0.02 \mathrm{mg}$; iron, $0.01 \mathrm{mg}$; copper, $0.0025 \mathrm{mg}$; iodine, $0.0003 \mathrm{mg}$; selenium, $0.00003 \mathrm{mg}$; folic acid, $0.69 \mathrm{mg}$; choline, $386 \mathrm{mg}$; riboflavin, $6.61 \mathrm{mg}$; biotin, $0.03 \mathrm{mg}$; vitamin B6, $1.38 \mathrm{mg}$; niacin, $27.56 \mathrm{mg}$; pantothenic acid, $6.61 \mathrm{mg}$; thiamine, $2.20 \mathrm{mg}$; menadione, $0.83 \mathrm{mg}$; vitamin B12, $0.01 \mathrm{mg}$; vitamin E, $16.53 \mathrm{IU}$; vitamin D3, 2,133 ICU; vitamin A, 7,716 IU. 
Table 2. Nutrient specifications ${ }^{1,2}$ of diets provided to broilers from d 1-21.

\begin{tabular}{|c|c|c|c|c|c|c|}
\hline Treatments & DCP & MDP & MCP & DFP & DMM & $\mathrm{MCP}+\mathrm{SiO}_{2}$ \\
\hline \multicolumn{7}{|c|}{ Calculated Nutrients (\%) } \\
\hline $\mathrm{ME}(\mathrm{kcal} / \mathrm{kg})$ & 3,000 & 3,000 & 3,000 & 3,000 & 3,000 & 3,000 \\
\hline Crude Protein & 20.00 & 20.00 & 20.00 & 20.00 & 20.00 & 20.00 \\
\hline Digestible Lysine & 1.20 & 1.20 & 1.20 & 1.20 & 1.20 & 1.20 \\
\hline Digestible. Methionine & 0.63 & 0.63 & 0.63 & 0.63 & 0.63 & 0.63 \\
\hline Digestible Methionine + Cysteine & 0.90 & 0.90 & 0.90 & 0.90 & 0.90 & 0.90 \\
\hline Digestible Threonine & 0.84 & 0.84 & 0.84 & 0.84 & 0.84 & 0.84 \\
\hline Digestible Tryptophan & 0.20 & 0.20 & 0.20 & 0.20 & 0.20 & 0.20 \\
\hline Calcium & 0.70 & 0.69 & 0.68 & 0.70 & 0.70 & 0.66 \\
\hline Phosphorus & 0.49 & 0.49 & 0.49 & 0.49 & 0.49 & 0.46 \\
\hline Ca:P & $1.44: 1$ & $1.42: 1$ & $1.41: 1$ & $1.44: 1$ & $1.43: 1$ & $1.43: 1$ \\
\hline nPP & 0.22 & 0.22 & 0.22 & 0.22 & 0.22 & 0.20 \\
\hline Sodium & 0.17 & 0.17 & 0.17 & 0.17 & 0.17 & 0.17 \\
\hline $\mathrm{CPDP}^{3}(\mathrm{~g})$ & 0.509 & 0.735 & 0.791 & 0.413 & 0.748 & 0.579 \\
\hline \multicolumn{7}{|c|}{ Analyzed Nutrients (\%) } \\
\hline Crude Protein ${ }^{4}$ & 18.7 & 18.6 & 18.5 & 18.2 & 17.9 & 17.5 \\
\hline Crude Fat $^{5}$ & 4.96 & 4.93 & 4.86 & 4.60 & 5.14 & 5.11 \\
\hline Calcium $^{6}$ & 0.63 & 0.74 & 0.74 & 0.75 & 0.74 & 0.69 \\
\hline Phosphorus $^{7}$ & 0.47 & 0.51 & 0.50 & 0.47 & 0.49 & 0.47 \\
\hline $\mathrm{nPP}^{8}$ & 0.24 & 0.28 & 0.27 & 0.25 & 0.24 & 0.23 \\
\hline Phytase Analysis (FTU/kg) ${ }^{9}$ & 1300 & 930 & 650 & 970 & 920 & 530 \\
\hline
\end{tabular}

$\mathrm{DCP}=$ dicalcium phosphate, $\mathrm{MDP}=$ monodicalcium phosphate, $\mathrm{MCP}=$ monocalcium phosphate, $\mathrm{DFP}=$ defluorinated phosphate, $\mathrm{DMM}=1 / 5 \mathrm{MCP}, 1 / 5$ monosodium phosphate, $3 / 5$ $\mathrm{DCP}$, and $\mathrm{MCP}+\mathrm{SiO}_{2}=\mathrm{MCP}+\mathrm{SiO}_{2}(67: 33)$.

${ }^{1}$ Metabolizable Energy and Available Phosphorus were based on Agristat values, as suggested by M. Donohue (2013).

${ }^{2}$ Digestible amino acids were based on values suggested by P. B. Tillman and W.A. Dozier (2013).

${ }^{3} \mathrm{CPDP}=$ Calculated prececal digestible $\mathrm{P}$ : Values were calculated using values from the CVB (2016) and IFP calculated values. Considering the DCP diet: DCP is included into the diet at $0.5 \%$ which is $5 \mathrm{~g}$ of IFP. The $\mathrm{P}$ content of DCP is $18.5 \%$; therefore, $0.93 \mathrm{~g}$ of $\mathrm{P}$ is added to the diet with the addition of DCP. The standard digestibility coefficient obtained from the CVB (2016) for DCP is 55\%, meaning that the digestible P supplied through DCP corresponds to $0.5 \mathrm{~g}$ (0.93 g x 55\%).

${ }^{4}$ AOAC Method 988.05, 920.87, 991.20; Kjeldahl.

${ }^{5}$ AOAC Method 920.39, 934.0; Ether Extraction.

${ }^{6}$ AOAC Method 968.08, 927.02, 935.13, 985.35; Atomic Absorption Spectrophotometry.

${ }^{7}$ AOAC Method 965.17; Spectrophotometry.

${ }^{8}$ Non-phytate phosphorus $=$ total phosphorus $(A O A C$ Method 965.17) $-[0.282 \mathrm{X}$ phytic acid

(AOAC Method 986.11)] x 100.

${ }^{9}$ AOAC Method 2000.12; Phytase.

*All diets were top dressed with 1,000 FTU/kg of phytase. 
Table 3. Descriptive characteristics of the inorganic feed phosphates and mixtures utilized in experimental diets.

\begin{tabular}{|l|c|c|c|c|c|c|}
\hline Treatments & DCP & MDP & MCP & DFP & DMM & MCP+SiO \\
\hline \multicolumn{7}{|c|}{ Calculated Values (\%) } \\
\hline Phosphorus & 18.5 & 19.0 & 22.7 & 18.0 & 20.4 & 15.2 \\
\hline Calcium & 23.0 & 16.5 & 16.0 & 30.0 & 17.1 & 10.7 \\
\hline Sodium & --- & 4.5 & --- & 5.3 & 4.0 & --- \\
\hline \multicolumn{7}{|c|}{ Analyzed Values (\%) } \\
\hline Phosphorus $^{1}$ & 19.2 & 19.6 & 22.5 & 19.0 & 20.6 & 13.7 \\
\hline Calcium $^{2}$ & 20.3 & 17.8 & 18.8 & 34.7 & 15.2 & 11.6 \\
\hline Sodium $^{3}$ & --- & 2.13 & --- & 2.55 & 1.78 & --- \\
\hline
\end{tabular}

$\mathrm{DCP}=$ dicalcium phosphate, $\mathrm{MDP}=$ monodicalcium phosphate, $\mathrm{MCP}=$ monocalcium phosphate, $\mathrm{DFP}=$ defluorinated phosphate, $\mathrm{DMM}=1 / 5 \mathrm{MCP}, 1 / 5$ monosodium phosphate, $3 / 5$ $\mathrm{DCP}$, and $\mathrm{MCP}+\mathrm{SiO}_{2}=\mathrm{MCP}+\mathrm{SiO}_{2}(67: 33)$.

${ }^{1}$ AOAC Method 965.17; Spectrophotometry.

${ }^{2}$ AOAC Method 968.08, 927.02, 935.13, 985.35; Atomic Absorption Spectrophotometry.

${ }^{3}$ AOAC Method 968.08, 935.13, 985.35; Atomic Absorption Spectrophotometry. 
Table 4. Growth performance of Ross x Ross 308 male broilers and contrast probability values recorded on d 7, 14 , and 21.

\begin{tabular}{|c|c|c|c|c|c|c|c|c|c|c|c|}
\hline & Treatments & DCP & MDP & MCP & DFP & DMM & $\mathrm{MCP}+\mathrm{SiO}_{2}$ & $\begin{array}{c}\text { Treatment } \\
P \text {-value }\end{array}$ & $\begin{array}{c}\text { Fisher's } \\
\text { LSD }\end{array}$ & $\begin{array}{c}\text { Treatment } \\
\text { SEM }\end{array}$ & $\begin{array}{c}\text { Linear } \\
\text { Contrasts }\end{array}$ \\
\hline \multirow{4}{*}{ d 7} & Bird Weight (kg) & 0.117 & 0.121 & 0.124 & 0.118 & 0.119 & 0.116 & 0.0689 & --- & 0.0019 & $\mathrm{a}$ \\
\hline & Pen FI ${ }^{1}(\mathrm{~kg})$ & 0.982 & 1.03 & 1.07 & 1.01 & 0.981 & 0.989 & 0.1141 & --- & 0.0248 & $\mathrm{a}$ \\
\hline & Bird LWG ${ }^{2}(\mathrm{~kg})$ & 0.075 & 0.080 & 0.082 & 0.077 & 0.077 & 0.075 & 0.0635 & --- & 0.0019 & $\mathrm{a}$ \\
\hline & $\mathrm{FCR}^{3}$ & 1.32 & 1.29 & 1.30 & 1.31 & 1.27 & 1.34 & 0.1234 & $\begin{array}{ll}-- \\
--\end{array}$ & 0.0185 & $\begin{array}{ll}-- \\
--\end{array}$ \\
\hline \multirow{4}{*}{ d 14} & Bird Weight $(\mathrm{kg})$ & $0.341^{b c}$ & $0.353^{\mathrm{ab}}$ & $0.356^{\mathrm{a}}$ & $0.342^{\mathrm{abc}}$ & $0.348^{\mathrm{abc}}$ & $0335^{\mathrm{c}}$ & 00460 & 00146 & 00051 & $a$ \\
\hline & Pen FI (kg) & 4.37 & 4.49 & 4.52 & 4.38 & 4.40 & 4.37 & 0.0944 & --- & 0.0463 & $\mathrm{a}$ \\
\hline & Bird LWG (kg) & 0.299 & 0.312 & 0.314 & 0.291 & 0.307 & 0.293 & 0.1151 & --- & 0.0072 & $\mathrm{a}$ \\
\hline & FCR & 1.49 & 1.45 & 1.46 & 1.47 & 1.47 & 1.53 & 0.1497 & --- & 0.0224 & --- \\
\hline & & & & & & & & & & & \\
\hline \multirow{4}{*}{ d 21} & Bird Weight (kg) & 0.751 & 0.767 & 0.779 & 0.750 & 0.752 & 0.740 & 0.2149 & --- & 0.0115 & $\mathrm{a}$ \\
\hline & Pen FI (kg) & 10.10 & 10.35 & 10.39 & 10.19 & 10.15 & 10.24 & 0.4318 & --- & 0.1144 & --- \\
\hline & Bird LWG (kg) & 0.710 & 0.726 & 0.738 & 0.708 & 0.711 & 0.699 & 0.2135 & --- & 0.0115 & $\mathrm{a}$ \\
\hline & FCR & 1.48 & 1.45 & 1.44 & 1.48 & 1.48 & 1.51 & 0.4397 & --- & 0.0240 & $\mathrm{a}$ \\
\hline
\end{tabular}

$\mathrm{DCP}=$ dicalcium phosphate, $\mathrm{MDP}=$ monodicalcium phosphate, $\mathrm{MCP}=$ monocalcium phosphate, $\mathrm{DFP}=$ defluorinated phosphate,

$\mathrm{DMM}=1 / 5 \mathrm{MCP}, 1 / 5$ monosodium phosphate, $3 / 5 \mathrm{DCP}$, and $\mathrm{MCP}+\mathrm{SiO}_{2}=\mathrm{MCP}+\mathrm{SiO}_{2}(67: 33)$.

${ }^{1} \mathrm{FI}=$ Feed Intake.

${ }^{2} \mathrm{LWG}=$ Live Weight Gain.

${ }^{3}$ Feed Conversion Ratio (Feed:Gain) was calculated using mortality weight.

${ }^{4}$ Significant $(\mathrm{P}<0.05)$ linear contrasts were expressed by letter as follows: $a=$ DCP vs. MCP; $b=$ MDP vs. DMM; and c = DCP vs.

$\mathrm{MCP}+\mathrm{SiO}_{2}$.

${ }^{\mathrm{a}-\mathrm{c}}$ Means within a column not sharing a common superscript differ significantly $(\mathrm{P}<0.05)$.

*Percent mortality was not significant in any time period. 
Table 5. Tibia ash and phosphorus and calcium digestibility analysis recorded on $\mathrm{d} 21$.

\begin{tabular}{|c|c|c|c|c|c|c|c|c|c|c|}
\hline Treatments & DCP & MDP & $\mathrm{MCP}$ & DFP & DMM & $\mathrm{MCP}+\mathrm{SiO}_{2}$ & $\begin{array}{c}\text { Treatment } \\
P \text {-value }\end{array}$ & $\begin{array}{c}\text { Fisher's } \\
\text { LSD }\end{array}$ & Treatment SEM & $\begin{array}{c}\text { Linear } \\
\text { Contrasts } 1 \\
\end{array}$ \\
\hline Tibia Ash (\%) & $47.2^{\mathrm{c}}$ & $48.0^{\mathrm{a}}$ & $47.8^{\mathrm{ab}}$ & $47.2^{\mathrm{c}}$ & $47.5^{\mathrm{bc}}$ & $47.4^{\mathrm{bc}}$ & 0.0078 & 0.4625 & 0.1624 & $\mathrm{~b}$ \\
\hline Tibia Ash (mg/chick) & $675.0^{\mathrm{c}}$ & $723.1^{\mathrm{ab}}$ & $769.0^{\mathrm{a}}$ & $712.8^{\mathrm{bc}}$ & $753.6^{\mathrm{ab}}$ & $708.3^{\mathrm{bc}}$ & 0.0026 & 46.066 & 16.1727 & $\mathrm{a}$ \\
\hline AID Ca Coefficient & $44.78^{\mathrm{c}}$ & $75.02^{\mathrm{a}}$ & $62.50^{\mathrm{b}}$ & $69.82^{\mathrm{a}}$ & $68.62^{\mathrm{ab}}$ & $68.92^{\mathrm{ab}}$ & $<0.0001$ & 7.0844 & 2.4872 & $a, b, c$ \\
\hline AID P Coefficient & $29.05^{\mathrm{c}}$ & $74.65^{\mathrm{a}}$ & $68.19^{\mathrm{b}}$ & $66.41^{\mathrm{b}}$ & $74.21^{\mathrm{ab}}$ & $74.87^{\mathrm{a}}$ & $<0.0001$ & 6.1734 & 2.1673 & $\mathrm{a}, \mathrm{c}$ \\
\hline $\begin{array}{l}\text { Digestible } \mathrm{Ca} \\
\text { Concentration }\end{array}$ & $0.280^{\mathrm{d}}$ & $0.557^{\mathrm{a}}$ & $0.463^{\mathrm{c}}$ & $0.523^{\mathrm{ab}}$ & $0.506^{\mathrm{bc}}$ & $0.476^{\mathrm{c}}$ & $<0.0001$ & 0.047 & 0.0165 & $\mathrm{a}, \mathrm{b}, \mathrm{c}$ \\
\hline $\begin{array}{l}\text { Digestible P } \\
\text { Concentration }\end{array}$ & $0.136^{\mathrm{d}}$ & $0.378^{\mathrm{a}}$ & $0.343^{b c}$ & $0.315^{\mathrm{c}}$ & $0.350^{\mathrm{ab}}$ & $0.350^{\mathrm{ab}}$ & $<0.0001$ & 0.0295 & 0.0103 & $a, b, c$ \\
\hline
\end{tabular}

$\mathrm{DCP}=$ dicalcium phosphate, $\mathrm{MDP}=$ monodicalcium phosphate, $\mathrm{MCP}=$ monocalcium phosphate, $\mathrm{DFP}=$ defluorinated phosphate,

$\mathrm{DMM}=1 / 5 \mathrm{MCP}, 1 / 5$ monosodium phosphate, $3 / 5 \mathrm{DCP}$, and $\mathrm{MCP}+\mathrm{SiO}_{2}=\mathrm{MCP}+\mathrm{SiO}_{2}(67: 33)$.

AID Ca Coefficient $=$ apparent ileal Ca digestibility coefficient; AID P Coefficient $=$ apparent ileal P digestibility coefficient;

${ }^{1}$ Significant $(\mathrm{P}<0.05)$ linear contrasts were expressed by letter as follows: $a=$ DCP vs. MCP; $b=$ MDP vs. DMM; and c = DCP vs.

$\mathrm{MCP}+\mathrm{SiO}_{2}$.

${ }^{\mathrm{a}-\mathrm{c}}$ Means within a column not sharing a common superscript differ significantly $(\mathrm{P}<0.05)$. 


\title{
CHAPTER 3
}

In vitro phytase activity post steam conditioning and pelleting may not consistently correlate with in vivo measurements among commercial phytases

\author{
A. E. Lamp*, N. E. Ward ${ }^{2}$, J. W. Wilson², and J. S. Moritz*1 \\ *Division of Animal and Nutritional Sciences, West Virginia University, Morgantown, \\ West Virginia, 26506; and ${ }^{2}$ DSM Nutritional Products Inc., Parsippany, NJ 07054 \\ Phone: 304-293-1911
}

Fax: 304-293-2232

${ }^{1}$ Corresponding Author: Joe.Moritz@mail.wvu.edu

Primary Audience: Feed Manufactures, Nutritionists, Researches 


\section{SUMMARY}

An experiment was conducted to evaluate correlations between in vitro phytase activity post pelleting and broiler performance, tibia mineralization, and plasma myo-inositol of broilers fed diets containing different phytase enzymes conditioned at three different temperatures $(70$, 80 , and $90^{\circ} \mathrm{C}$ ). Dietary treatments included a positive control (PC; $0.9 \%$ calcium $(\mathrm{Ca})$ and $0.4 \%$ non-phytate phosphorus (nPP)) and negative control ( $\mathrm{NC} ; 0.7 \% \mathrm{Ca}$ and $0.2 \% \mathrm{nPP})$ and four additional diets containing commercially available phytase products (A, B, C, and D) added to the NC based on analyzed activity and manufacturer's recommendations. Treatments were arranged in a 6 (diet formulation) x 3 (conditioning temperature) factorial in a randomized complete block design with ten replications of ten male broilers fed each of 18 dietary treatments for 21 days. Correlations were determined with categorical and replicated data. A conditioning temperature $\mathrm{x}$ diet formulation interaction occurred for $\mathrm{d} 14$ and 21 FCR and d 21 tibia ash (P < 0.05). Day 14 and 21 FCR increased and d21 tibia ash decreased as conditioning temperature was increased from 70 to $90^{\circ} \mathrm{C}$ for all phytase treatments except Phytase B that did not demonstrate performance or tibia ash detriment. Correlations were most apparent with replicated data. In vitro Phytase A activity correlated with $\mathrm{d} 21 \mathrm{FCR}(\mathrm{P}=0.04, \mathrm{r}=-0.38)$, Phytase $\mathrm{B}$ did not demonstrate correlation $(\mathrm{P}>0.05)$, Phytase $\mathrm{C}$ correlated with tibia ash $\mathrm{mg} /$ chick $(\mathrm{P}=0.01, \mathrm{r}=$ $0.46)$, and Phytase $\mathrm{D}$ showed a moderate correlation with tibia ash $\mathrm{mg} /$ chick $(\mathrm{P}=0.16, \mathrm{r}=0.26)$ and plasma myo-inositol concentration $(\mathrm{P}=0.15, \mathrm{r}=0.27)$. This study did not demonstrate a common in vivo performance metric that was correlated with in vitro phytase activity post manufacture among commercial phytase products that decreased in activity due to increased conditioning temperature. Both in vivo and in vitro measurements should be assessed to properly evaluate the efficacy of an enzyme. 
Key words: in vitro phytase activity, correlation, myo-inositol, feed manufacture, tibia mineralization

\section{DESCRIPTION OF PROBLEM}

The majority of commercial broiler diets contain an exogenous enzyme and undergo a feed manufacture process that results in pelleted feed. The most valuable exogenous enzyme in poultry diets is phytase (Bedford et al., 2016); this enzyme is used in commercial broiler diets to improve phosphorus (P) availability, diet cost, and environmental impact (Bedford, 2000; Selle and Ravindran, 2007). The improvement of $\mathrm{P}$ availability is achieved by the cleavage of $\mathrm{P}$ from phytate (myo-inositol hexakisdihydrogen phosphate; IP6) by phytase. Complete dephosphorylation of phytate produces a myo-inositol ring (Cowieson et al., 2011; Sommerfeld et al., 2018b). Therefore, improvements due to the addition of a phytase enzyme in a poultry diet can be indicated by increased weight gain, tibia mineralization, nutrient digestibility, and blood plasma myo-inositol concentration (Cowieson et al., 2006; Bedford et al., 2016).

The feed manufacture process involves subjecting mash feed to increased heat, moisture, and pressure which can be detrimental to a mixer-added phytase enzyme (Jongbloed and Kemme, 1990; Thomas et al., 1998). While these increased conditions can be beneficial for pellet quality, they may have a beneficial or detrimental effect on bird performance depending on ingredients. To evaluate the phytase activity of a feed post-manufacture, an in vitro phytase analysis must be employed. Methods utilized include the AOAC official method (AOAC International, 2000; Method 2000.12), Phytex (Phytex LLC, Portland, ME), Engelen et al. (1994, 2001), modifications to these methods, etc. If in vitro phytase analysis could predict in vivo measurements of a broiler, money, time, and resources could potentially be saved. However, the 
phytase assay has been found to be variable; the relative SD for repeatability and reproducibility have been determined to range from 2.2 to 10.6 and 5.4 to $1.5 \%$, respectively (Gizzi et al., 2008).

The loss of phytase activity post feed manufacture may negatively affect bird performance due to the fact that diets may become deficient in available P (Loop et al., 2012). This was observed in a study conducted by Homan et al. (2019) where broiler diets containing three different microbial phytases conditioned at three different temperatures $\left(82,88\right.$, and $\left.93^{\circ} \mathrm{C}\right)$ were evaluated and in vitro phytase activity and in vivo measurements were assessed. The researchers concluded that as conditioning temperature increased, generally, in vitro phytase activity decreased, as well as in vivo broiler performance and tibia mineralization $(\mathrm{P}<0.05)$ (Homan et al., 2019). A study conducted by Wilkinson et al. (2013) examined the effect of four conditioning temperatures $\left(75,80,85\right.$, and $\left.90^{\circ} \mathrm{C}\right)$ on in vitro phytase activity of two microbial phytases and subsequent in vivo measurements. The scientists observed a slight increase in in vitro phytase activity and no difference in $\mathrm{d} 21$ feed intake (FI) and BW gain when conditioning temperature was increased from 75 to $80^{\circ} \mathrm{C}$. When conditioning temperature was increased from 80 to $90^{\circ} \mathrm{C}$, in vitro phytase activity and $\mathrm{d} 21 \mathrm{FI}$ decreased, and no difference in $\mathrm{BW}$ gain was observed (P < 0.05) (Wilkinson et al., 2013). However, a study conducted by Loop et al. (2012) found opposing results. This study evaluated broiler diets containing nine different genetic variants of an Escherichia coli (E. coli)-derived mixer-added phytase conditioned at three different temperatures $\left(71,77,82^{\circ} \mathrm{C}\right)$ and fed the $77^{\circ} \mathrm{C}$ treatments to describe how in vitro retained phytase activity related to in vivo measurements. The diet containing the highest in vitro phytase activity produced birds with the lowest in vivo measurements; conversely, the diet containing the lowest in vitro phytase activity produced birds with the highest in vivo measurements $(\mathrm{P}<0.05)$. They concluded that in vitro phytase activity did not positively 
correlate with broiler performance or tibia mineralization measures (Loop et al., 2012).

Therefore, the current study hypothesized that decreased in vitro phytase activity in feed due to increased steam conditioning temperature during pelleting is correlated to a decrease in in vivo measurements upon feeding. The objective of the study was to feed broilers diets containing different phytase enzymes conditioned at different temperatures and correlate in vitro phytase activity post pelleting with broiler performance, tibia mineralization, and plasma myo-inositol concentration.

\section{MATERIALS AND METHODS}

\section{Phytases and Dietary Treatments}

Diets were corn and soybean meal based and were formulated to contain calculated nutrient values that were based on commercial (Donohue, 2013) and research recommendations (Tillman and Dozier, 2013) (Table 1). A total of six diet formulations and three conditioning temperatures were utilized for this experiment, creating a total of 18 dietary treatments. Diet formulations consisted of a positive control (PC) formulated to $0.9 \%$ calcium (Ca) and $0.4 \%$ non-phytate $\mathrm{P}$ (nPP) and a negative control (NC) formulated to $0.7 \% \mathrm{Ca}$ and $0.2 \% \mathrm{nPP}$. The remaining four diet formulations were created by adding four commercial phytase products (Phytase A, B, C, and D) to the NC diet. The three conditioning temperatures utilized were 70 $\left(158^{\circ} \mathrm{F}\right), 80\left(176^{\circ} \mathrm{F}\right)$, and $90^{\circ} \mathrm{C}\left(194^{\circ} \mathrm{F}\right)(\mathbf{7 0}, \mathbf{8 0}$, and 90$)$.

The commercial phytase products included a preparation of a bacterial-derived 6-phytase (EC 3.1.3.26) produced by Aspergillus niger, a phytase sourced from a Buttiauxella species bacterium expressed in a Trichoderma reesei fungus, a phytase sourced from Citrobactor braakii expressed in submerged fermentation of an Aspergillus oryzae micro-organism, and a phytase sourced from an Escherichia coli species bacterium expressed in a Trichoderma reesei fungus. 
Enzyme treatments were not specifically identified because the study focus was on correlating in vitro and in vivo measures and not product testing. The aforementioned phytase products were added to the NC diet based on analyzed activity and manufacturer's recommendations. One phytase unit (FTU) was defined as the amount of enzyme required to release $1 \mu \mathrm{mol}$ of inorganic phosphate per minute from a $5.1 \mathrm{~m} M$ sodium phytate at $\mathrm{pH} 5.5$ and $37^{\circ} \mathrm{C}$. (Engelen et al., 2001).

\section{Feed Manufacture}

All feed was manufactured at the West Virginia University (WVU) pilot feed mill. All diets were mixed for 10 minutes dry and 10 minutes post soybean oil addition in a one-ton vertical screw mixer. Washed builders sand was used to standardize volume among the different phytase product inclusions to a $0.03 \%$ total inclusion. Ten $1,000 \mathrm{~g}$ mash samples per treatment ( 6 mash treatments) were collected as the mixer was emptied into a surge bin located above a California Pellet Mill (CPM) Conditioner (Model C18INF6.5H, CPM Company, Crawfordsville, IN). A sample was collected approximately every 20 seconds as the mixer emptied until 10 samples were collected as to receive a representative sample of the entire batch. Each mash sample was analyzed in duplicate for phytase activity (AOAC International, 2000; Method 2000.12).

All treatments were steam conditioned in a sequential manner $\left(70,80\right.$, and $\left.90^{\circ} \mathrm{C}\right)$ for 60 seconds using a CPM Conditioner with steam pressure throttled to $276 \mathrm{kpa}$ prior to the Masoneilan Valve and entrance to the conditioner. Treatments were then pelleted at steady state conditions at a constant rate of 1.2 tonne/hr using a 40-horsepower California Pellet Mill (Model 5K324BL205-Z Master Model Pellet Mill, CPM Company, Crawfordsville, IN) with a 4.76 (effective thickness) x $38.1 \mathrm{~mm}$ (length) pellet die without relief. This production rate is approximately $30 \%$ above manufacture's recommended capacity to mimic industry practice. 
After pelleting, cooled pellets were ran through a roller mill to achieve a small uniform crumble size among treatments.

Five 500 g pellet samples per treatment (18 pelleted treatments) were collected from a horizontal belt cooler. One of the five samples was collected approximately every 4 minutes from the cooler until 5 samples were obtained as to receive a representative sample of the entire batch. Each sample was analyzed in duplicate for phytase activity (AOAC International, 2000; Method 2000.12); phytase recovery is reported in Table 3. Multiple crumbled samples of each treatment were collected, pooled, and sent to a commercial laboratory for nutrient analysis (NP Analytical Laboratories, St. Louis, MO).

Variables measured during feed manufacture included mill load and hot pellet temperature (HPT). Pellet durability index (PDI) and modified pellet durability index (MPDI) tests were conducted 24 hours post-manufacture. Measurements of PDI were also obtained using the New Holmen Pellet Tester (NHPT) (Lignotech USA, Inc., Rothschild, WI). Particle size of the crumbled feed was determined using a Ro-Tap Particle Size Analyzer (Model RX-29 type $110 \mathrm{~V} 60 \mathrm{H} 2$, WS Tyler, Mentor, $\mathrm{OH})$. Methods used to measure the above variables are further explained by Corey et al. (2014). For each treatment, approximately 100 grams of hot pellets leaving the pellet die and approximately $100 \mathrm{~g}$ of cooled pellets from the belt cooler were collected for moisture analysis (AOAC International, 2000; Method 934.01).

All crumbled diets were stored in a $4.6 \mathrm{~m} \times 2.4 \mathrm{~m}$ insulated storage room equipped with a dehumidifier (Hisense 50-Pint 2-Speed Dehumidifier, Suwanee, GA) to equilibrate moisture content among treatments. Temperature and humidity of the storage room was recorded daily. Moisture analysis was conducted weekly on the diets located in the storage room. Moisture analysis was completed by weighing 2 gram samples from a 100 gram sample collected of each 
treatment into crucibles and drying them in an oven at $105^{\circ} \mathrm{F}$ for $16 \mathrm{~h}$ (AOAC International, 2000; Method 934.01). Pellet durability index, MPDI, NHPT, and moisture determination were analyzed in duplicate, and the averages of these values can be found in Table 3.

\section{In vitro Phytase Analysis}

Phytase activity was determined via the AOAC method 2000.12 (AOAC International, 2000). Feed samples (50 g sample) were extracted with $500 \mathrm{~mL}$ of distilled water containing $0.01 \%$ Tween 20. A $100 \mu \mathrm{L}$ extract was then diluted with $300 \mathrm{~mL}$ of acetate buffer at $\mathrm{pH} 5.5$. After preincubation of the diluted extract at $37^{\circ} \mathrm{C}, 0.8 \mathrm{~mL}$ of phytic acid from rice was added, and the sample was incubated for $30 \mathrm{~min}$ at $37^{\circ} \mathrm{C}$. The reaction was stopped by adding $0.8 \mathrm{~mL}$ of molybdate/vanadate stop reagent. A blank was included for each sample; after preincubation of the blank, the stop reagent was added before adding the substrate. The absorbance of the yellow complex was measured at $415 \mathrm{~nm}$ with a spectrophotometer. The blank value was subtracted from the sample value, and the released phosphate was quantified with a phosphate standard curve (Jones et al., 2010).

\section{Live Bird Performance}

A total of one thousand eight hundred 1-day-old male Hubbard x Ross 708 (Hubbard LLC, Pikeville, TN; Aviagen, Inc., Huntsville, AL) chicks were obtained from a commercial hatchery (Longeneckers Hatchery, Elizabethtown, PA); the parent stock of these chicks were 38 weeks old. On d1, the chicks were weighed, 10 birds at a time, and were allocated to 180 raised wire cages based on weight to create uniform initial pen weights. One of the 18 dietary treatments was randomly assigned to each pen within a block. A block consisted of 18 adjacent cages, and there were 10 blocks or replications per treatment. Chicks were housed in raised wire cages in a cross-ventilated, negative-pressure room. Four identical rooms were utilized; each 
containing 48 cages, creating a total of 180 cages. Feed was placed in external feed troughs and water was supplied through a nipple drinker system; both feed and water were provided for ad libitum consumption. Room temperature for the 1 -day-old chicks was set at $32^{\circ} \mathrm{C}$, and gradually decreased to $29^{\circ} \mathrm{C}$ for the second week and $26^{\circ} \mathrm{C}$ for the third week of the study to create optimal rearing conditions. From d1 to 6 birds were exposed to 24 h light; and after d6, the hours of light were decreased gradually until $6 \mathrm{~h}$ dark was reached on $\mathrm{d} 21$.

The study period was a total of 21 days, and performance measurements were taken on d14 and 21. Measured variables associated with performance included: starting pen weight, d14 and 21 ending bird weight, pen FI, mortality corrected FCR, bird live weight gain (LWG), and pen percent mortality. Tibia ash (\%), tibia ash (mg/chick), and plasma myo-inositol concentration were calculated on tibiae and blood collected on d21. All animals were reared according to protocols approved by West Virginia University Animal Care and Use Committee.

\section{Plasma Myo-inositol Concentration and Tibia Mineralization}

On $d 21$, three birds per pen were stunned with electricity and exsanguinated via the jugular vein. Approximately $1 \mathrm{~mL}$ of blood from the jugular vein per bird was collected in a BD Vacutainer (Dickinson and Company, Franklin Lakes, NJ) tube containing EDTA. Samples were pooled by pen and centrifuged at $1500 \mathrm{~g}$ for $10 \mathrm{~min}$ at $4^{\circ} \mathrm{C}$. The plasma was collected in a cryogenic tube (Biotix, San Diego, CA) and placed in a $-80^{\circ} \mathrm{C}$ freezer before shipment. Plasma myo-inositol concentration was determined by mass spectrometry using an UPLC-TQD system (Waters, Milford, MA) according to the method described by Leung et al. (2011).

The left tibia was excised from the three birds used for blood collection as well as two extra birds per pen, creating a total of 5 tibiae collected per pen used to determine tibia ash $\%$ and $\mathrm{mg} / \mathrm{chick}$. The two extra birds were euthanized via cervical dislocation. Excised tibiae were 
placed in a freezer until tibia ash analysis began. Tibiae were placed in a drying oven at $105^{\circ} \mathrm{C}$ for $48 \mathrm{~h}$. Once dried, tibiae were wrapped in filter paper and placed in a Soxhlet apparatus and refluxed with petroleum ether for $16 \mathrm{~h}$. Following fat extraction, the tibiae were allowed to dry. Tibiae were then removed from the filter paper, weighed, and placed in an ashing oven at $600^{\circ} \mathrm{C}$ for $18 \mathrm{~h}$. The inorganic matter remaining was weighed, and ash content was determined (Boney and Moritz, 2017).

\section{Statistical Analysis}

An overall comparison of all eighteen treatments was conducted using ANOVA. A 6 (diet formulation) $\times 3$ (conditioning temperature) factorial in a randomized complete block design was used to explore main effects and interactions. However, birds provided PC and NC produced expected performance, tibia mineralization, and plasma myo-inositol concentration (results not shown). Therefore, a 4 (phytase) $\times 3$ (conditioning temperature) factorial in a randomized complete block design was used to explore main effects and interactions of treatments containing phytase. The experimental unit was a pen of 10 male broilers. Pen location within the room was used as blocking criterion, and all data were analyzed using the GLM procedure of SAS (SAS Institute, 2013). Means were further explored using Fischer's LSD test when the main effect interaction was significant. Alpha was designated as 0.05 for significance and 0.10 for trending data, and letter superscripts were used to denote differences among treatment means. Correlations between replicated in vitro phytase activity, and replicated performance measurements, tibia mineralization, and plasma myo-inositol concentrations across block were determined using the PROC CORR procedure in SAS. In addition, since in vitro phytase activity was performed on feed obtained from a single batch of feed without replication of the manufacture process, these data were considered categorical and additional study metrics 
were averaged across each treatment to be similar for a second correlation

determination. Strength of correlation was determined using $\mathrm{r}$ values and accompanying $P$ values to determine the significance of correlation.

\section{RESULTS AND DISSCUSSION}

\section{Dietary Treatments}

A cursory discussion of descriptive analyzed nutrients of each treatment may be useful when considering treatment effects (Table 2). The NC diet was formulated to $0.7 \% \mathrm{Ca}, 0.2 \%$ nPP, and $22.06 \%$ CP. Negative Control 80 contained the least Ca (0.59\%), while Phytase B 70 and Phytase C 90 contained the most $\mathrm{Ca}(0.77 \%)$ of all the treatments containing the $\mathrm{NC}$ basal diet. Phytase A 70 had the highest P content, while Phytase B 80 had the lowest P content of all treatments containing NC. Phytase B 80 and 90 had the lowest nPP (0.22\%) value, and Phytase D 70 had the highest nPP $(0.28 \%)$ value of all the treatments containing the NC basal diet. Crude protein ranged from 22.0 (Phytase A $90^{\circ} \mathrm{C}$ ) to $23.8 \%\left(\mathrm{NC} 80^{\circ} \mathrm{C}\right.$ ) for treatments containing the NC basal diet.

The PC diet was formulated to $0.9 \% \mathrm{Ca}, 0.4 \% \mathrm{nPP}$, and $21.97 \% \mathrm{CP}$. Positive control 90 had the highest $\mathrm{Ca}(0.84 \%)$ content while PC 80 had the lowest $\mathrm{Ca}(0.71 \%)$ content compared to all PC treatments. Positive control 70 and 90 had the highest nPP (0.40\%) and P (0.65) value of the three PC treatments. For the PC diets, $\mathrm{CP}$ ranged from $22.5\left(\mathrm{PC} 70^{\circ} \mathrm{C}\right)$ to $24.0 \%\left(\mathrm{PC} 80^{\circ} \mathrm{C}\right)$. These differences likely reflect analytical variation since basal formulations were similar.

\section{Feed Manufacture}

Feed manufacture and pellet quality data were not replicated and should be considered descriptive (Table 3). Treatments were manufactured at the beginning of October; during that time, ambient temperature ranged from 22.2 to $30.6^{\circ} \mathrm{C}$ and ambient humidity ranged from 51 to 
79\%. A 100\% mill load was based on full load amps as per the pellet mill motor name plate. The pellet mill load ranged from 39 to $49 \%$ throughout feed manufacture. As conditioning temperature increased, HPT and pellet quality also increased for each treatment. Several authors have observed similar results (Beaman et al., 2012; Rigby et al., 2018; Homan et al., 2019). Hot pellet temperature was increased compared to steam conditioning temperature at $70^{\circ} \mathrm{C}$ and decreased at $90^{\circ} \mathrm{C}$ for all treatments and ranged from 72.4 to $87.3^{\circ} \mathrm{C}$. New Holmen Pellet Tester values ranged from 13.54 to $67.14 \%$, PDI values ranged from 40.14 to $76.89 \%$, and MPDI values ranged from 24.69 to $71.25 \%$. Increased pellet quality can be associated with increased steam input, starch gelatinization, and protein gelation (Moritz et al., 2003; Loar et al., 2014; Rigby et al., 2018; Homan et al., 2019). Particle size of the crumbles of each treatment fed to broilers was within $209 \mu \mathrm{m}$ of each other, ranging from 1135 to $1344 \mu \mathrm{m}$. A majority of the average moisture of the cooled pellets was decreased after the feed was placed in an insulated storage room equipped with a dehumidifier. Average moisture of crumbled diets located in the insulated storage room equipped with a dehumidifier ranged from 10.20 to $12.88 \%$ for the total 3-week period.

\section{In vitro Phytase Activity}

Mixer samples indicated a chloride ion coefficient of variation below $10 \%$ that indirectly suggested phytase was evenly distributed throughout the batch of feed prior to steam conditioning (results not shown). The in vitro phytase activity post-pelleting for each diet containing phytase was below the target dose. The feed manufacture process exposed the enzymes to increased temperature, moisture, and pressure which could have caused denaturation (Jongbloed and Kemme, 1990; Thomas et al., 1998). Phytase activity decreased as conditioning temperature increased from 70 to $80^{\circ} \mathrm{C}$ for Phytase $\mathrm{B}$ and $\mathrm{C}$; however, phytase activity slightly 
increased for Phytase A and D (Table 3). Phytase activity decreased for all phytases when conditioning temperature was increased from 80 to $90^{\circ} \mathrm{C}$. Phytase $\mathrm{B}$ was the most thermally stable at all conditioning temperatures compared to the other diets. Homan et al. (2019) also observed in vitro phytase activity decrease for an Buttiauxella phytase expressed in Trichoderma reesei (B Trich), an E. coli phytase expressed in Pichia pastoris (E Pichia), and an E. coli phytase expressed in Trichoderma reesei (E Trich) when conditioning temperature was increased from 88 to $93^{\circ} \mathrm{C}$; additionally, E Trich was the most thermally stable of the three enzymes. Wilkinson et al. (2013) observed a slight increase in in vitro phytase activity when conditioning temperature was increased from 75 to $80^{\circ} \mathrm{C}$ for an $\mathrm{E}$ Trich and $\mathrm{E}$ Pichia phytase. These authors also observed a decrease in in vitro phytase activity when conditioning temperature was increased from 80 to $90^{\circ} \mathrm{C}$; additionally, E Trich was found to be more thermally stable than E Pichia (Wilkinson et al., 2013).

\section{Live Bird Performance}

Overall comparison. All performance metrics measured on d14 and 21 were significant for the overall comparison of all eighteen treatments $(\mathrm{P}<0.01)$ (Table 4). Birds provided PC 90 had the highest d14 average ending bird weight and subsequent bird LWG; birds provided NC 70 and 80 had the lowest, and all other treatments were intermediate $(\mathrm{P}<0.0001)$. Birds provided PC 80 had the highest d14 pen FI, and birds provided NC 80 had the lowest; all other treatments were intermediate $(\mathrm{P}<0.0001)$. Phytase D 70 fed birds had the lowest FCR, while birds fed Phytase D 80 had the highest; all other treatments were intermediate $(\mathrm{P}=0.0002)$. Birds provided PC 90 had the highest d21 average ending bird weight and subsequent LWG, and NC 70 fed birds had the lowest; all other treatments were intermediate $(\mathrm{P}<0.0001)$. Birds fed PC 80 and 90 had the highest d21 pen FI, while birds provided NC 80 had the lowest, and all other 
treatments were intermediate $(\mathrm{P}<0.0001)$. Phytase C 70 and Phytase D 70 fed birds had the lowest FCR, and birds provided Phytase D 80 had the highest; all other treatment were intermediate $(\mathrm{P}<0.0001)$.

Factorial. Broiler chicks provided PC and NC produced expected performance, tibia mineralization, and plasma myo-inositol differences $(\mathrm{P}<0.05)$; therefore, a $4 \times 3$ factorial arrangement was utilized to examine the differences between treatments containing phytase. Phytase $\mathrm{x}$ conditioning temperature interactions were observed for d14 and 21 FCR. Feed conversion ratio increased as conditioning temperature was increased from 70 to $90^{\circ} \mathrm{C}$; however, Phytase B was not affected $(\mathrm{P}<0.05)$. The authors speculate that this could be due to the fact that Phytase B was the most thermally stable at $90^{\circ} \mathrm{C}$ compared to the other diets. No phytase $\mathrm{x}$ conditioning temperature interactions were observed for Homan et al. (2019) and Wilkinson et al. (2013) $(\mathrm{P}>0.05)$. Significant differences were observed for the main effect phytase for d14 and 21 pen FI, demonstrating that pen FI was highest when birds were fed Phytase B, followed by Phytase $\mathrm{A}$ being intermediate, and birds fed Phytase $\mathrm{C}$ and $\mathrm{D}$ had the lowest $(\mathrm{P}<0.05)$. Similar results were observed for Homan et al. (2019); birds provided a diet containing 1000 FTU $/ \mathrm{kg}$ of E Trich had the highest pen FI compared to the other treatments $(\mathrm{P}<0.001)$. On d14, the main effect phytase was significant for average ending bird weight and subsequent bird LWG, demonstrating that birds fed Phytase B had the highest d14 average ending bird weight and bird LWG; Phytase A and D fed birds were intermediate, and birds provided Phytase C had the lowest $(\mathrm{P}<0.05)$.

\section{Tibia Mineralization}

Overall comparison. Birds provided PC 70 and 90 had the highest tibia ash (\%), and NC 70 fed birds had the lowest; all other treatments were intermediate $(\mathrm{P}<0.0001)$ (Table 5). Positive 
control 90 fed birds had the highest tibia ash (mg/chick) while NC 70, 80, and 90 fed birds had the lowest; all other treatments were intermediate $(\mathrm{P}<0.0001)$.

Factorial. Phytase x conditioning temperature interactions were observed for tibia ash; tibia ash decreased as conditioning temperature was increased from 70 to $90^{\circ} \mathrm{C}$. This was true for all treatments except Phytase B; tibia ash increased as conditioning temperature was increased from 70 to $90^{\circ} \mathrm{C}(\mathrm{P}<0.05)$. The authors speculate that this could be due to the fact that Phytase B was the most thermally stable at $90^{\circ} \mathrm{C}$ compared to the other diets. In the current study, in vitro phytase activity decreased for all phytases when conditioning temperature was increased from 70 to $90^{\circ} \mathrm{C}$. Homan et al. (2019) also observed tibia ash (\% and $\left.\mathrm{mg} / \mathrm{chick}\right)$ decrease as conditioning temperature increased, regardless of the phytase product utilized $(\mathrm{P}<0.05)$. In the current study, in vitro phytase activity differences were no greater than $10 \%$ between diets conditioned at 70 and $80^{\circ} \mathrm{C}$; however, for Phytase A, C, and D, tibia ash (mg/chick) was significantly different between diets conditioned at 70 and $80^{\circ} \mathrm{C}$.

\section{Plasma Myo-inositol Concentration}

Overall comparison. Phytase A 70 and 80 and Phytase B 80 fed birds had the highest concentration of myo-inositol in their plasma, and birds fed NC 70 had the lowest; all other treatments were intermediate $(\mathrm{P}<0.0001)$ (Table 5).

Factorial. Birds fed diets conditioned at $80^{\circ} \mathrm{C}$ had the highest plasma myo-inositol concentrations, diets conditioned at $70^{\circ} \mathrm{C}$ were intermediate, and birds fed diets conditioned at $90^{\circ} \mathrm{C}$ had the lowest myo-inositol concentrations $(\mathrm{P}=0.0221)$. In the current study, in vitro phytase activity decreased for all phytases when conditioning temperature was increased from 80 to $90^{\circ} \mathrm{C}$. Diets conditioned at $80^{\circ} \mathrm{C}$ were able to cleave more $\mathrm{P}$ from phytate compared to diets conditioned at $90^{\circ} \mathrm{C}$, possibly due to the increased phytase activity in diets conditioned at $80^{\circ} \mathrm{C}$. 
Phytase A fed birds had the highest plasma myo-inositol concentrations; Phytase B and D fed birds were intermediate, and birds fed Phytase $C$ has the lowest $(P=0.0047)$. Past studies have reported an increased plasma myo-inositol concentration of broilers provided a phytase enzyme compared to control diets (Cowieson et al., 2014; Sommerfeld et al, 2018a; Sommerfeld et al, 2018b). Cowieson et al. (2014) utilized a phytase sourced from Citrobactor braakii expressed in submerged fermentation of an Aspergillus oryzae micro-organism dosed at 1,000 FTU/kg and conditioned at $72^{\circ} \mathrm{C}$. The scientists reported a plasma myo-inositol concentration of $56.75 \mathrm{mg} / \mathrm{L}$ for 22 day old broilers. In the current study, birds provided Phytase D 70 had a plasma myoinositol concentration of $37.04 \mathrm{mg} / \mathrm{L}$. Diets utilized in the Cowieson et al. (2014) study had increased phytase activity (+350 FTU $/ \mathrm{kg}$ ) and total P content compared to diets fed in the current study.

\section{Correlations}

Categorical. Calculations for the categorical correlations were performed as follows: For Phytase A, five samples of pellets conditioned at $70^{\circ} \mathrm{C}$ were collected and analyzed for in vitro phytase activity. Each sample collected was ran in duplicate, creating a total of 10 data points. The 10 data points were averaged to represent in vitro Phytase A activity at $70^{\circ} \mathrm{C}$. This process was repeated for each diet containing phytase and each conditioning temperature $(70,80$, and $\left.90^{\circ} \mathrm{C}\right)$. Average ending bird weight was averaged using the 10 data points from each block (10 blocks) to represent average ending bird weight of birds fed Phytase A 70. This process was repeated for each performance measurement, diet containing phytase, and each conditioning temperature. $\mathrm{N}=3$.

While the authors appreciate that use of categorical data decreases the power of correlation analysis, in vitro phytase activity data was performed on feed obtained from a single 
batch of feed without replication of the manufacture process. These data were considered categorical and additional study metrics were averaged across each conditioning temperature to be similar for correlation determination (Table 6). Categorical in vitro phytase activity of Phytase A inversely correlated with pen FI $(r=-0.9999 ; \mathrm{P}=0.0027)$; and a trend was observed for positive correlation with plasma myo-inositol concentration $(\mathrm{r}=0.9768 ; \mathrm{P}=0.1373)$. A trend was observed demonstrating that in vitro phytase activity of Phytase B inversely correlated with pen FI $(\mathrm{r}=-0.9935 ; \mathrm{P}=0.0724)$ and tibia ash $(\mathrm{mg} / \mathrm{chick})(\mathrm{r}=-0.9885 ; \mathrm{P}=0.0027)$. In vitro phytase activity of Phytase $\mathrm{C}$ did not correlate with averaged conditioning temperature or in vivo metrics $(\mathrm{P}>0.05)$. In vitro phytase activity of Phytase $\mathrm{D}$ positively correlated with plasma myoinositol concentration $(\mathrm{r}=0.9970 ; \mathrm{P}=0.0492)$.

Replicated. Calculations for the replicated correlations were performed as follows: For Phytase A, five samples of pellets conditioned at $70^{\circ} \mathrm{C}$ were collected and analyzed for in vitro phytase activity. Each sample collected was ran in duplicate, creating a total of 10 data points. This process was repeated for each diet containing phytase and each conditioning temperature. Average ending bird weight was represented using the 10 data points from each block (10 blocks) for birds fed Phytase A 70. This process was repeated for each performance measurement, diet containing phytase, and each conditioning temperature. $\mathrm{N}=30$.

More correlations were observed when utilizing replicated data (Table 7). Replicated in vitro phytase activity of all commercial phytases utilized in the study inversely correlated with conditioning temperature $(\mathrm{P}<0.01)$. In vitro phytase activity of Phytase A inversely correlated with FCR $(\mathrm{r}=-0.3819 ; \mathrm{P}=0.0373)$. No correlation was observed between in vitro phytase activity of Phytase B and in vivo metrics. In vitro phytase activity of Phytase C positively correlated with tibia ash $(\mathrm{mg} / \mathrm{chick})(\mathrm{r}=0.4622 ; \mathrm{P}=0.0101)$; and a trend was observed for 
inverse correlation with FCR $(\mathrm{r}=-0.3413 ; \mathrm{P}=0.0649)$. A trend was observed demonstrating that in vitro phytase activity of Phytase D positively correlated with tibia ash $(\mathrm{mg} / \mathrm{chick})(\mathrm{r}=0.2621$; $\mathrm{P}=0.1617)$, tibia ash $(\%)(\mathrm{r}=0.2549 ; \mathrm{P}=0.1741)$, and plasma $m y o$-inositol concentration $(\mathrm{r}=$ 0.2708; $\mathrm{P}=0.1478)$. Loop et al. (2012) generated Pearson correlation coefficients between in vitro phytase activity of pelleted diets and in vivo metrics and found that in vitro phytase activity did not positively correlate with performance or bone mineralization measures. These scientists recommended that in vivo measurements beyond in vitro activity assays should be utilized to best understand efficacy of an enzyme. There are several in vivo variables of the bird that affect enzyme efficacy; therefore, it is difficult to assume an enzyme's efficacy based solely on in vitro analysis (Malathi and Devegowda, 2001).

\section{CONCLUSION AND APPLICATIONS}

1. In general, in vitro phytase activity decreased with increased conditioning temperature. A phytase $\mathrm{x}$ conditioning temperature interaction occurred for $\mathrm{d} 14$ and 21 FCR and $\mathrm{d} 21$ tibia ash $(\mathrm{P}<0.05)$. Day 14 and 21 FCR increased and $\mathrm{d} 21$ tibia ash decreased as conditioning temperature was increased from 70 to $90^{\circ} \mathrm{C}$ for all phytase treatments except phytase B that did not demonstrate performance or tibia ash detriment.

2. Correlations were most apparent with replicated data, demonstrating the importance of analyzing multiple samples for in vitro phytase activity; however, correlations between in vitro phytase activity and in vivo metrics were not consistent among phytase treatments.

3. This study did not demonstrate a common in vivo metric that correlated with in vitro phytase activity post manufacture among commercial phytase products that decreased in activity due to increased conditioning temperature. Both in vivo and in vitro measurements should be assessed to properly evaluate the efficacy of an enzyme. 


\section{REFERENCES AND NOTES}

AOAC International. 2000. Official Methods of Analysis of the AOAC International, 17th ed., Gaithersburg, MD.

Beaman, K. R., K. G. S. Lilly, C. K. Gehring, P. J. Turk, and J. S. Moritz. 2012. Influence of pelleting on the efficacy of an exogenous enzyme cocktail using broiler performance and metabolism. J. Appl. Poult. Res. 21(4):744-756.

Bedford, M. R. 2000. Exogenous enzymes in monogastric nutrition-Their current value and future benefits. Anim. Feed Sci. Technol. 86(1-2):1-13.

Bedford, M. R., C. L. Walk, and H. V. Masey O’Neill. 2016. Assessing measurements in feed enzyme research: Phytase evaluations in broilers. J. Appl. Poult. Res. 25(2):305-314.

Boney, J. W. and J. S. Moritz. 2017. Phytase dose effects in practically formulated diets that vary in ingredient composition on feed manufacturing and broiler performance. J. Appl. Poult. Res. 26:273-285.

Corey, A. M., K. G. S. Wamsley, T. S. Winowiski, and J. S. Moritz. 2014. Effects of calcium lignosulfonate, mixer-added fat, and feed form on feed manufacture and broiler performance, J. Appl. Poult. Res. 23(3):418-428.

Cowieson, A. J., T. Acamovic, and M. R. Bedford. 2006. Supplementation of Corn-Soy-Based Diets with an Eschericia coli-Derived Phytase: Effects on Broiler Chick Performance and the Digestibility of Amino Acids and Metabolizability of Minerals and Energy. Poult. Sci. 85(8):1389-1397.

Cowieson, A. J., P. Wilcocock, and M. R. Bedford. 2011. Super-dosing effects of phytase in poultry and other monogastrics. World's Poult. Sci. J. 67:225-235. 
Cowieson, A. J., R. Aureli, P. Guggenbuhl, and F. Fru-Nji. 2014. Possible involvement of myoinositol in the physiological response of broilers to high doses of microbial phytase. Anim. Prod. Sci. 55(6):710-719.

Donohue. M. 2013. The Challenges in Feeding Broilers in Times of High and Volatile Feed Ingredient Costs: How to Cover the Costs? 2013 Mid-Atlantic Nutrition Conference proceedings.

Engelen, A. J., F. C. van der Heeft, P. H. G. Randsdorf, and E. L. C. Smit. 1994. Simple and rapid determination of phytase activity. J. AOAC Int. 77:760-764.

Engelen, A. J., F. C. van der Heeft, P. H. G. Randsdorp, W. A. C. Somers, J. Schaefer, and B. J. C. van der Vat. 2001. Determination of phytase activity in feed by a colorimetric enzymatic method: Collaboration interlaboratory study. J. AOAC Int. 84:629-633.

Gizzi, G., P. Thyregod, C. von Holst, G. Bertin, K. Vogel, M. Faurschou-Isaksen, R. Betz, R. Murphy, and B. B. Andersen. 2008. Determination of phytase activity in feed: Interlaboratory study. J. AOAC Int. 91:259-267.

Homan, V. B., J. W. Boney, and J. S. Moritz. 2019. Effects of steam conditioning temperatures on commercial phytases and subsequent broiler performance and tibia mineralization. App. Animal Sci. 35(3):298 - 303.

Jones, C. K., M. D. Tokach, S. S. Dritz, B. W. Ratliff, N. L. Horn, R. D. Goodband, J. M. DeRouchey, R. C. Sulabo, and J. L. Nelssen. 2010. Efficacy of different commercial phytase enzymes and development of an available phosphorus release curve for Escherichia coli-derived phytases in nursery pigs. J. Anim. Sci. 88:3631 - 3644. 
Jongbloed, A. W., and P. A. Kemme. 1990. Effect of pelleting mixed feeds on phytase activity and the apparent absorbility of phosphorus and calcium in pigs. Anim. Feed Sci. Technol. 28:233-242.

Leung K-Y., K. Mills, K. A. Burren, A. J. Copp, and N. D. E. Greene. 2011. Quantitative analysis of myo-inositol in urine, blood and nutritional supplements by high-performance liquid chromatography tandem mass spectrometry. Journal of Chromatography. B, Analytical Technologies in the Biomedical and Life Sciences. 879:2759-2763.

Loar, R. E., K. G. S. Wamsley, A. Evans, J. S. Moritz, and A. Corzo. 2014. Effects of varying conditioning temperature and mixer-added fat on feed manufacturing efficiency, 28- to 42-day broiler performance, early skeletal effects, and true amino acid digestibility. J. Appl. Poult. Res. 23:444-455.

Loop, S. A., K. G. S. Lilly, L. K. Shires, C. K. Gehring, K. R. Beaman, M. E. Persia, and J. S. Moritz. 2012. The phytase analytical activity of pelleted diets may not adequately describe efficacy in the bird. J. Appl. Poult. Res. 21:492-501.

Malathi, V., and G. Devegowda. 2001. In vitro evaluation of nonstarch polysaccharide digestibility of feed ingredients by enzymes. Poult. Sci. 80:302-305.

Moritz, J. S., K. R. Cramer, K. J. Wilson, and R. S. Beyer. 2003. Feed manufacture and feeding of rations with graded levels of added moisture formulated to different energy densities. J. Appl. Poult. Res. 12:371-381.

Rigby, T. R., B. G. Glover, K. L. Foltz, J. W. Boney, and J. S. Moritz. 2018. Effects of modifying diet and feed manufacture concern areas that are notorious for decreasing pellet quality. J. Appl. Poult. Res. 27(2): 240-248.

SAS Institute. 2013. The SAS system for Windows 2013. Release 9.3 SAS Inst. Inc., Cary, NC. 
Selle, P. H., and V. Ravindran. 2007. Microbial phytase in poultry nutrition. Anim. Feed Sci. Technol. 135:1-41.

Sommerfeld, V., S. Künzel, M. Schollenberger, I. Kühn, and M. Rodehutscord. 2018a. Influence of phytase or myo-inositol supplements on performance and phytate degradation products in the crop, ileum, and blood of broiler chickens. Poult. Sci. 97:920-929.

Sommerfeld, V., M. Schollenberger, I. Kühn, and M. Rodehutscord. 2018b. Interactive effects of phosphorus, calcium, and phytase supplements on products of phytate degradation in the digestive tract of broiler chickens. Poult. Sci. 97(4):1177-1188.

Thomas, M., T.V. Vliet, , and A.F.B. Van Der Poel. 1998. Physical quality of pelleted animal feed 3. Contribution of Feedstuff component. Animal Feed Science and Technology 70: $59-78$.

Tillman, P. B. and W.A. Dozier. 2013. Current Amino Acid Considerations for Broilers: Requirements, Ratios, Economics for 8 - 14 day broilers. www.thepoultryfederation.com.

Wilkinson, S. J., C. L. Walk, M. R. Bedford, and A. J. Cowieson. 2013. Influence of conditioning temperature on the postpellet recovery and efficacy of 2 microbial phytases for broiler chicks. J. Appl. Poult. Res. 22(2):308-313. 
Table 1. Diet composition and nutrient specifications ${ }^{1,2}$ of the positive and negative control diets provided during the trial.

\begin{tabular}{|l|c|c|}
\hline \multicolumn{1}{|c|}{ Ingredients } & Negative Control & Positive Control \\
\hline Corn & 54.00 & 52.54 \\
\hline Soybean Meal (48\%) & 39.94 & 39.94 \\
\hline Soybean Oil & 3.00 & 3.51 \\
\hline Dicalcium P & 0.73 & 1.81 \\
\hline Limestone & 1.15 & 1.02 \\
\hline Salt & 0.33 & 0.33 \\
\hline DL - Methionine & 0.32 & 0.32 \\
\hline Vitamin/Mineral Premix ${ }^{3}$ & 0.25 & 0.25 \\
\hline Sodium Bicarbonate & 0.10 & 0.10 \\
\hline Threonine & 0.09 & 0.09 \\
\hline Lysine & 0.06 & 0.06 \\
\hline Phytase/Sand & 0.03 & 0.03 \\
\hline \multicolumn{2}{|c|}{ Calculated Nutrients $(\%)$} & 3,000 \\
\hline ME (kcal/kg) & 3,000 & 21.97 \\
\hline Crude Protein & 22.06 & 0.90 \\
\hline Calcium & 0.70 & 0.40 \\
\hline nPP & 0.20 & 0.17 \\
\hline Sodium & 0.17 & 1.20 \\
\hline Digestible Lysine & 1.20 & 0.63 \\
\hline Digestible Methionine & 0.63 & 0.93 \\
\hline Digestible Methionine and Cysteine & 0.94 & 0.84 \\
\hline Digestible Threonine & 0.84 & 0.25 \\
\hline Digestible Tryptophan & 0.25 & $A 915$ \\
\hline
\end{tabular}

${ }^{1}$ Metabolizable Energy and Available Phosphorus were based on Agristat values, as suggested by Donohue (2013).

${ }^{2}$ Digestible amino acids were based on values suggested by Tillman and Dozier (2013).

${ }^{3}$ Vitamin mineral premix (NB3000, Nutrablend, Neosho, MO) supplied the following per $\mathrm{kg}$ of diet: manganese, $0.02 \mathrm{mg}$; zinc, $0.02 \mathrm{mg}$; iron, $0.01 \mathrm{mg}$; copper, $0.0025 \mathrm{mg}$; iodine, $0.0003 \mathrm{mg}$; selenium, $0.00003 \mathrm{mg}$; folic acid, $0.69 \mathrm{mg}$; choline, $386 \mathrm{mg}$; riboflavin, $6.61 \mathrm{mg}$; biotin, $0.03 \mathrm{mg}$; vitamin B6, $1.38 \mathrm{mg}$; niacin, $27.56 \mathrm{mg}$; pantothenic acid, $6.61 \mathrm{mg}$; thiamine, $2.20 \mathrm{mg}$; menadione, $0.83 \mathrm{mg}$; vitamin B12, $0.01 \mathrm{mg}$; vitamin E, $16.53 \mathrm{IU}$; vitamin D3, 2,133 ICU; vitamin A, 7,716 IU. 
Table 2. Calculated and analyzed nutrients of diets provided to broilers from d1-21.

\begin{tabular}{|c|c|c|c|c|c|c|c|c|}
\hline \multirow{2}{*}{$\begin{array}{c}\text { Diet } \\
\text { Formulation }\end{array}$} & \multirow{2}{*}{$\begin{array}{c}\text { Conditioning } \\
\text { Temperature }\left({ }^{\circ} \mathrm{C}\right)\end{array}$} & \multicolumn{3}{|c|}{ Calculated Nutrients $(\%)$} & \multicolumn{4}{|c|}{ Analyzed Nutrients (\%) } \\
\hline & & Crude Protein & Calcium & $\mathrm{nPP}$ & Crude Protein $^{1}$ & Calcium $^{2}$ & Phosphorus $^{3}$ & $\mathrm{nPP}^{4}$ \\
\hline \multirow{3}{*}{$\begin{array}{c}\text { Negative } \\
\text { Control }\end{array}$} & 70 & \multirow{3}{*}{22.06} & \multirow{3}{*}{0.70} & \multirow{3}{*}{0.20} & 22.7 & 0.76 & 0.50 & 0.25 \\
\hline & 80 & & & & 23.8 & 0.59 & 0.48 & 0.24 \\
\hline & 90 & & & & 22.3 & 0.72 & 0.47 & 0.23 \\
\hline \multirow{3}{*}{ Phytase A } & 70 & \multirow{3}{*}{22.06} & \multirow{3}{*}{0.70} & \multirow{3}{*}{0.20} & 22.7 & 0.72 & 0.53 & 0.27 \\
\hline & 80 & & & & 23.6 & 0.66 & 0.48 & 0.23 \\
\hline & 90 & & & & 22.0 & 0.74 & 0.47 & 0.23 \\
\hline \multirow{3}{*}{ Phytase B } & 70 & \multirow{3}{*}{22.06} & \multirow{3}{*}{0.70} & \multirow{3}{*}{0.20} & 23.6 & 0.77 & 0.52 & 0.27 \\
\hline & 80 & & & & 23.6 & 0.60 & 0.45 & 0.22 \\
\hline & 90 & & & & 22.7 & 0.68 & 0.48 & 0.22 \\
\hline \multirow{3}{*}{ Phytase C } & 70 & \multirow{3}{*}{22.06} & \multirow{3}{*}{0.70} & \multirow{3}{*}{0.20} & 23.3 & 0.72 & 0.51 & 0.26 \\
\hline & 80 & & & & 22.7 & 0.68 & 0.47 & 0.24 \\
\hline & 90 & & & & 22.7 & 0.77 & 0.47 & 0.25 \\
\hline \multirow{3}{*}{ Phytase D } & 70 & \multirow{3}{*}{22.06} & \multirow{3}{*}{0.70} & \multirow{3}{*}{0.20} & 22.8 & 0.69 & 0.52 & 0.28 \\
\hline & 80 & & & & 23.4 & 0.70 & 0.49 & 0.23 \\
\hline & 90 & & & & 22.7 & 0.68 & 0.48 & 0.24 \\
\hline \multirow{3}{*}{$\begin{array}{l}\text { Positive } \\
\text { Control }\end{array}$} & 70 & \multirow{3}{*}{21.97} & \multirow{3}{*}{0.90} & \multirow{3}{*}{0.40} & 22.5 & 0.81 & 0.65 & 0.40 \\
\hline & 80 & & & & 24.0 & 0.71 & 0.62 & 0.38 \\
\hline & 90 & & & & 22.6 & 0.84 & 0.65 & 0.40 \\
\hline
\end{tabular}

${ }^{1}$ AOAC Method 988.05, 920.87, 991.20; Kjeldahl.

${ }^{2}$ AOAC Method 968.08, 927.02, 935.13, 985.35; Atomic Absorption Spectrophotometry.

${ }^{3}$ AOAC Method 965.17; Spectrophotometry.

${ }^{4}$ Non-phytate phosphorus = total phosphorus $(A O A C$ Method 965.17) $-[0.282 \mathrm{x}$ phytic acid $($ AOAC Method 986.11) $]$ x 100. 
Table 3. Descriptive pellet quality, crumble particle size, moisture analysis, and in vitro phytase recovery data collected postmanufacture.

\begin{tabular}{|c|c|c|c|c|c|c|c|c|c|c|c|c|}
\hline \multirow{2}{*}{$\begin{array}{c}\text { Diet } \\
\text { Formulation }\end{array}$} & \multirow{2}{*}{$\begin{array}{c}\text { Conditioning } \\
\text { Temperature }\left({ }^{\circ} \mathrm{C}\right)\end{array}$} & \multirow{2}{*}{$\begin{array}{l}\mathrm{HPT}^{1} \\
\left({ }^{\circ} \mathrm{C}\right)\end{array}$} & \multicolumn{3}{|c|}{ Pellet Quality (\%) } & \multirow{2}{*}{$\begin{array}{c}\text { Particle } \\
\text { Size }(\mu \mathrm{m})\end{array}$} & \multicolumn{5}{|c|}{ Average Moisture ${ }^{5}(\%)$} & \multirow{2}{*}{$\begin{array}{c}\text { Phytase } \\
\text { Recovery }^{8}(\%)\end{array}$} \\
\hline & & & $\mathrm{NHPT}^{2}$ & $\mathrm{PDI}^{3}$ & $\mathrm{MPDI}^{4}$ & & $\begin{array}{c}\text { Hot } \\
\text { Pellet }^{6}\end{array}$ & $\begin{array}{l}\text { Cooled } \\
\text { Pellet }^{7}\end{array}$ & Week 1 & Week 2 & Week 3 & \\
\hline \multirow{3}{*}{$\begin{array}{l}\text { Negative } \\
\text { Control }\end{array}$} & 70 & 74.2 & 22.41 & 55.65 & 40.99 & $1248 \pm 2.2$ & 14.62 & 12.71 & 13.16 & 11.11 & 10.20 & -- \\
\hline & 80 & 79.5 & 36.49 & 58.82 & 45.42 & $1305 \pm 2.1$ & 14.78 & 13.28 & 12.88 & 12.05 & 11.42 & -- \\
\hline & 90 & 85.6 & 54.55 & 74.15 & 64.92 & $1338 \pm 2.1$ & 15.58 & 15.89 & 12.29 & 12.07 & 10.97 & -- \\
\hline \multirow{3}{*}{ Phytase A } & 70 & 72.4 & 13.54 & 40.14 & 24.69 & $1135 \pm 2.2$ & 13.49 & 12.31 & 11.66 & 11.51 & 10.90 & 88 \\
\hline & 80 & 79.7 & 25.34 & 53.44 & 41.40 & $1311 \pm 2.1$ & 14.80 & 13.50 & 12.37 & 12.20 & 11.23 & 96 \\
\hline & 90 & 86.3 & 44.06 & 66.28 & 56.86 & $1204 \pm 2.2$ & 15.62 & 13.68 & 11.97 & 11.59 & 11.10 & 30 \\
\hline \multirow{3}{*}{ Phytase B } & 70 & 75.3 & 14.76 & 43.10 & 28.41 & $1209 \pm 2.1$ & 14.04 & 12.64 & 11.24 & 11.44 & 10.99 & 99 \\
\hline & 80 & 81.2 & 22.62 & 50.37 & 37.15 & $1344 \pm 2.1$ & 13.60 & 12.95 & 12.20 & 11.80 & 11.58 & 98 \\
\hline & 90 & 86.2 & 42.71 & 65.64 & 56.42 & $1335 \pm 2.1$ & 15.11 & 13.60 & 11.85 & 12.34 & 11.22 & 74 \\
\hline \multirow{3}{*}{ Phytase C } & 70 & 72.4 & 17.35 & 47.99 & 34.09 & $1252 \pm 2.1$ & 13.84 & 12.44 & 11.67 & 11.95 & 10.39 & 83 \\
\hline & 80 & 79.9 & 31.09 & 58.82 & 46.81 & $1172 \pm 2.2$ & 14.97 & 13.37 & 11.45 & 11.10 & 11.63 & 75 \\
\hline & 90 & 86.4 & 67.14 & 76.89 & 71.25 & $1253 \pm 2.1$ & 15.99 & 14.24 & 12.43 & 11.62 & 11.12 & 28 \\
\hline \multirow{3}{*}{ Phytase D } & 70 & 73.4 & 15.43 & 45.82 & 32.44 & $1166 \pm 2.2$ & 13.90 & 12.65 & 11.62 & 11.58 & 10.80 & 80 \\
\hline & 80 & 79.4 & 28.91 & 58.50 & 47.03 & $1192 \pm 2.1$ & 14.88 & 12.87 & 12.07 & 11.68 & 11.53 & 80 \\
\hline & 90 & 86.5 & 50.93 & 72.97 & 64.84 & $1280 \pm 2.1$ & 15.41 & 14.43 & 12.75 & 12.83 & 11.50 & 37 \\
\hline \multirow{3}{*}{ Positive Control } & 70 & 72.8 & 16.32 & 45.85 & 30.18 & $1236 \pm 2.2$ & 14.04 & 12.61 & 11.38 & 10.99 & 10.98 & -- \\
\hline & 80 & 81.6 & 34.32 & 59.34 & 49.02 & $1276 \pm 2.1$ & 15.13 & 13.57 & 12.67 & 11.99 & 11.40 & -- \\
\hline & 90 & 87.3 & 52.49 & 72.01 & 63.33 & $1319 \pm 2.1$ & 15.72 & 14.05 & 11.93 & 11.91 & 12.43 & -- \\
\hline
\end{tabular}

${ }^{1} \mathrm{HPT}=$ Hot pellet temperature.

${ }^{2}$ NHPT $=$ New Holmen Pellet Tester.

${ }^{3} \mathrm{PDI}=$ Pellet Durability Index.

${ }^{4}$ MPDI $=$ Modified Pellet Durability Index.

${ }^{5}$ AOAC Method 934.01.

${ }^{6} \mathrm{Hot}$ pellets collected directly post pellet die extrusion.

${ }^{7}$ Cooled pellets collected post horizontal belt cooler. Pellets were next crumbled to a common particle size and stored in a dehumidified room to equilibrate moisture.

${ }^{8}$ (Analyzed pellet phytase / analyzed mash phytase) x 100, AOAC method 2000.12; Phytase. 
Table 4. Performance data obtained from 14 and 21-day old broilers.

\begin{tabular}{|c|c|c|c|c|c|c|c|c|c|c|}
\hline \multirow{2}{*}{$\begin{array}{l}\text { Diet } \\
\text { Formulation }\end{array}$} & \multirow{2}{*}{$\begin{array}{c}\text { Conditioning } \\
\text { Temperature }\left({ }^{\circ} \mathrm{C}\right)\end{array}$} & \multirow{2}{*}{$\begin{array}{l}\text { Starting Pen } \\
\text { Weight }^{1}(\mathrm{~kg})\end{array}$} & \multicolumn{4}{|c|}{$\mathrm{d} 14$} & \multicolumn{4}{|c|}{$\mathrm{d} 21$} \\
\hline & & & $\begin{array}{l}\text { Ending Bird } \\
\text { Weight (kg) }\end{array}$ & Pen $\mathrm{FI}^{2}(\mathrm{~kg})$ & $\mathrm{FCR}^{3}$ & $\begin{array}{c}\text { Bird } \\
\mathrm{LWG}^{4}(\mathrm{~kg})\end{array}$ & $\begin{array}{l}\text { Ending Bird } \\
\text { Weight }(\mathrm{kg})\end{array}$ & Pen FI (kg) & FCR & $\begin{array}{c}\text { Bird } \\
\text { LWG }(\mathrm{kg})\end{array}$ \\
\hline \multirow{3}{*}{$\begin{array}{l}\text { Negative } \\
\text { Control }\end{array}$} & 70 & 0.402 & $0.430^{\mathrm{f}}$ & $4.73^{\mathrm{gh}}$ & $1.21^{\mathrm{fg}}$ & $0.390^{\mathrm{f}}$ & $0.838^{\mathrm{f}}$ & $10.27^{\mathrm{e}}$ & $1.30^{\mathrm{de}}$ & $0.797^{\mathrm{f}}$ \\
\hline & 80 & 0.405 & $0.428^{\mathrm{f}}$ & $4.61^{\mathrm{h}}$ & $1.22^{\text {efg }}$ & $0.388^{\mathrm{f}}$ & $0.845^{\mathrm{ef}}$ & $10.20^{\mathrm{e}}$ & $1.31^{\mathrm{cde}}$ & $0.805^{\mathrm{ef}}$ \\
\hline & 90 & 0.403 & $0.436^{\mathrm{ef}}$ & $4.87^{\text {defg }}$ & $1.23^{\text {bcdef }}$ & $0.396^{\mathrm{ef}}$ & $0.848^{\mathrm{ef}}$ & $10.60^{\mathrm{de}}$ & $1.32^{\mathrm{bcd}}$ & $0.807^{\mathrm{ef}}$ \\
\hline \multirow{3}{*}{ Phytase A } & 70 & 0.403 & $0.451^{b c}$ & $4.95^{\mathrm{cdef}}$ & $1.21^{\text {efg }}$ & $0.410^{\mathrm{bc}}$ & $0.888^{\text {bcd }}$ & $10.87^{\mathrm{cd}}$ & $1.30^{\mathrm{de}}$ & $0.848^{\text {bcd }}$ \\
\hline & 80 & 0.404 & $0.444^{\text {cde }}$ & $4.91^{\text {cdefg }}$ & $1.24^{\text {abcdef }}$ & $0.404^{\text {cde }}$ & $0.886^{\text {bcd }}$ & $10.84^{\mathrm{cd}}$ & $1.31^{\text {bcd }}$ & $0.845^{\text {bcd }}$ \\
\hline & 90 & 0.403 & $0.444^{\mathrm{cde}}$ & $5.02^{\text {abcde }}$ & $1.25^{\mathrm{ab}}$ & $0.404^{\text {cde }}$ & $0.889^{\text {bcd }}$ & $11.11^{\mathrm{abc}}$ & $1.33^{\mathrm{ab}}$ & $0.849^{\text {bcd }}$ \\
\hline \multirow{3}{*}{ Phytase B } & 70 & 0.404 & $0.451^{\mathrm{bc}}$ & $5.05^{\mathrm{abcd}}$ & $1.24^{\text {abcdef }}$ & $0.411^{\mathrm{bc}}$ & $0.883^{\mathrm{bcd}}$ & $11.03^{\mathrm{abc}}$ & $1.32^{\mathrm{bcd}}$ & $0.843^{\mathrm{bcd}}$ \\
\hline & 80 & 0.403 & $0.452^{\mathrm{bc}}$ & $5.07^{\mathrm{abcd}}$ & $1.23^{\text {abcdef }}$ & $0.412^{\mathrm{bc}}$ & $0.895^{\mathrm{abc}}$ & $11.07^{\mathrm{abc}}$ & $1.31^{\mathrm{bcd}}$ & $0.855^{\mathrm{abc}}$ \\
\hline & 90 & 0.404 & $0.449^{\text {bcd }}$ & $5.08^{\mathrm{abc}}$ & $1.24^{\mathrm{abcd}}$ & $0.409^{\text {bcd }}$ & $0.899^{\mathrm{abc}}$ & $11.31^{\mathrm{ab}}$ & $1.32^{\mathrm{bcd}}$ & $0.859^{\mathrm{abc}}$ \\
\hline \multirow{3}{*}{ Phytase C } & 70 & 0.403 & $0.438^{\text {def }}$ & $4.84^{\text {efg }}$ & $1.22^{\text {defg }}$ & $0.400^{\mathrm{def}}$ & $0.885^{\text {bcd }}$ & $10.75^{\mathrm{cd}}$ & $1.29^{\mathrm{e}}$ & $0.845^{\text {bcd }}$ \\
\hline & 80 & 0.402 & $0.437^{\text {def }}$ & $4.80^{\text {fgh }}$ & $1.22^{\mathrm{efg}}$ & $0.400^{\text {def }}$ & $0.875^{\mathrm{cd}}$ & $10.57^{\mathrm{de}}$ & $1.30^{\mathrm{de}}$ & $0.835^{\mathrm{cd}}$ \\
\hline & 90 & 0.404 & $0.444^{\text {cde }}$ & $4.95^{\mathrm{cdef}}$ & $1.24^{\text {abcdef }}$ & $0.404^{\text {cde }}$ & $0.886^{\mathrm{bcd}}$ & $10.91^{\text {bcd }}$ & $1.32^{\mathrm{bcd}}$ & $0.846^{\mathrm{bcd}}$ \\
\hline \multirow{3}{*}{ Phytase D } & 70 & 0.403 & $0.451^{\mathrm{bc}}$ & $4.90^{\text {cdefg }}$ & $1.20^{\mathrm{g}}$ & $0.411^{\mathrm{bc}}$ & $0.886^{\mathrm{bcd}}$ & $10.85^{\mathrm{cd}}$ & $1.29^{\mathrm{e}}$ & $0.846^{\text {bcd }}$ \\
\hline & 80 & 0.403 & $0.434^{\mathrm{ef}}$ & $4.94^{\text {cdef }}$ & $1.26^{\mathrm{a}}$ & $0.393^{\text {ef }}$ & $0.866^{\mathrm{de}}$ & $10.90^{\text {bcd }}$ & $1.34^{\mathrm{a}}$ & $0.826^{\mathrm{de}}$ \\
\hline & 90 & 0.403 & $0.446^{\mathrm{cde}}$ & $4.98^{\text {bcdef }}$ & $1.24^{\mathrm{abcde}}$ & $0.405^{\text {cde }}$ & $0.876^{\mathrm{cd}}$ & $10.93^{\mathrm{bcd}}$ & $1.33^{\mathrm{abc}}$ & $0.836^{\mathrm{cd}}$ \\
\hline \multirow{3}{*}{ Positive Control } & 70 & 0.402 & $0.454^{\mathrm{abc}}$ & $5.04^{\text {abcd }}$ & $1.23^{\text {bcdef }}$ & $0.414^{\mathrm{abc}}$ & $0.908^{\mathrm{ab}}$ & $11.11^{\mathrm{abc}}$ & $1.30^{\mathrm{de}}$ & $0.868^{\mathrm{ab}}$ \\
\hline & 80 & 0.403 & $0.459^{\mathrm{ab}}$ & $5.20^{\mathrm{a}}$ & $1.24^{\mathrm{abc}}$ & $0.418^{\mathrm{ab}}$ & $0.908^{\mathrm{ab}}$ & $11.45^{\mathrm{a}}$ & $1.32^{\mathrm{bcd}}$ & $0.868^{\mathrm{ab}}$ \\
\hline & 90 & 0.404 & $0.465^{\mathrm{a}}$ & $5.15^{\mathrm{ab}}$ & $1.22^{\text {cdef }}$ & $0.424^{\mathrm{a}}$ & $0.919^{\mathrm{a}}$ & $11.39^{\mathrm{a}}$ & $1.31^{\mathrm{cde}}$ & $0.878^{\mathrm{a}}$ \\
\hline \multicolumn{2}{|c|}{ Treatment $P$-value } & 0.5126 & $<0.0001$ & $<0.0001$ & 0.0002 & $<0.0001$ & $<0.0001$ & $<0.0001$ & $<0.0001$ & $<0.0001$ \\
\hline \multicolumn{2}{|c|}{ Fisher's LSD } & --- & 0.0126 & 0.197 & 0.0256 & 0.0126 & 0.0254 & 0.4235 & 0.0203 & 0.0254 \\
\hline \multicolumn{2}{|c|}{ Treatment SEM } & 0.0008 & 0.005 & 0.071 & 0.009 & 0.005 & 0.009 & 0.152 & 0.007 & 0.009 \\
\hline \multicolumn{11}{|c|}{ Marginal Means } \\
\hline Phytase A & --- & 0.403 & $0.447^{\mathrm{ab}}$ & $4.96^{\mathrm{ab}}$ & 1.23 & $0.406^{\mathrm{ab}}$ & 0.888 & $10.94^{\mathrm{ab}}$ & $1.32^{\mathrm{a}}$ & 0.847 \\
\hline Phytase B & --- & 0.403 & $0.451^{\mathrm{a}}$ & $5.07^{\mathrm{a}}$ & 1.24 & $0.410^{\mathrm{a}}$ & 0.893 & $11.14^{\mathrm{a}}$ & $1.32^{\mathrm{a}}$ & 0.852 \\
\hline Phytase C & --- & 0.403 & $0.440^{\mathrm{b}}$ & $4.86^{\mathrm{b}}$ & 1.22 & $0.399^{\mathrm{b}}$ & 0.882 & $10.75^{\mathrm{b}}$ & $1.30^{\mathrm{b}}$ & 0.842 \\
\hline Phytase D & $\begin{array}{ll}-- \\
\end{array}$ & 0.403 & $0.444^{\mathrm{ab}}$ & $4.94^{\mathrm{b}}$ & 1.23 & $0.403^{\mathrm{ab}}$ & 0.876 & $10.89^{\mathrm{b}}$ & $1.32^{\mathrm{a}}$ & 0.836 \\
\hline \multicolumn{2}{|c|}{ SEM } & 0.0005 & 0.003 & 0.041 & 0.005 & 0.003 & 0.005 & 0.083 & 0.004 & 0.005 \\
\hline--- & 70 & 0.403 & 0.448 & 4.93 & $1.22^{\mathrm{b}}$ & 0.407 & 0.886 & 10.88 & $1.30^{\mathrm{b}}$ & 0.845 \\
\hline $\begin{array}{ll}-- \\
\end{array}$ & 80 & 0.403 & 0.442 & 4.93 & $1.24^{\mathrm{a}}$ & 0.402 & 0.880 & 10.85 & $1.32^{\mathrm{a}}$ & 0.840 \\
\hline $\begin{array}{ll}-- \\
\end{array}$ & 90 & 0.403 & 0.446 & 5.01 & $1.24^{\mathrm{a}}$ & 0.406 & 0.888 & 11.06 & $1.32^{\mathrm{a}}$ & 0.847 \\
\hline \multicolumn{2}{|c|}{ SEM } & 0.0004 & 0.002 & 0.035 & 0.004 & 0.002 & 0.004 & 0.072 & 0.004 & 0.004 \\
\hline \multicolumn{11}{|c|}{ Main Effects and Interactions } \\
\hline \multicolumn{2}{|c|}{ Phytase } & 0.9256 & 0.0396 & 0.0069 & 0.2714 & 0.0403 & 0.1346 & 0.0127 & 0.0472 & 0.1350 \\
\hline \multicolumn{2}{|c|}{ Conditioning Temperature } & 0.3755 & 0.1947 & 0.2423 & 0.0001 & 0.2021 & 0.4928 & 0.0762 & $<0.0001$ & 0.4989 \\
\hline \multicolumn{2}{|c|}{ Phytase x Conditioning Temp } & 0.6445 & 0.3424 & 0.9648 & 0.0055 & 0.3394 & 0.6870 & 0.9327 & 0.0041 & 0.6857 \\
\hline
\end{tabular}


${ }^{1}$ Starting pen weights were based on 10 birds/pen.

${ }^{2} \mathrm{FI}=$ Feed Intake.

${ }^{3}$ Feed Conversion Ratio (Feed:Gain) was calculated using mortality weight.

${ }^{4} \mathrm{LWG}=$ Live Weight Gain.

${ }^{\mathrm{a} h}$ Means within a column not sharing a common superscript differ significantly $(\mathrm{P}<0.05)$.

*Percent mortality was not significant in any time period. 
Table 5. Tibia ash and plasma myo-inositol concentration data obtained from 21-day old broilers.

\begin{tabular}{|c|c|c|c|c|}
\hline Diet Formulation & $\begin{array}{c}\text { Conditioning } \\
\text { Temperature }\left({ }^{\circ} \mathrm{C}\right)\end{array}$ & Tibia Ash (\%) & $\begin{array}{l}\text { Tibia Ash } \\
\text { (mg/chick) }\end{array}$ & $\begin{array}{c}\text { Plasma } M y o^{-} \\
\text {inositol }(\mathrm{mg} / \mathrm{L})\end{array}$ \\
\hline \multirow{3}{*}{ Negative Control } & 70 & $44.2^{j}$ & $711.6^{\mathrm{g}}$ & $28.15^{\mathrm{g}}$ \\
\hline & 80 & $45.0^{\mathrm{i}}$ & $726.5^{\mathrm{g}}$ & $31.60^{\text {defg }}$ \\
\hline & 90 & $45.2^{\mathrm{i}}$ & $701.3^{\mathrm{g}}$ & $33.27^{\text {bcde }}$ \\
\hline \multirow{3}{*}{ Phytase A } & 70 & $47.2^{\text {cdefg }}$ & $927.7^{\mathrm{d}}$ & $38.35^{\mathrm{a}}$ \\
\hline & 80 & $46.9^{\text {defg }}$ & $856.2^{\text {ef }}$ & $38.21^{\mathrm{a}}$ \\
\hline & 90 & $47.1^{\text {cdefg }}$ & $854.4^{\mathrm{ef}}$ & $37.17^{\mathrm{ab}}$ \\
\hline \multirow{3}{*}{ Phytase B } & 70 & $47.4^{\mathrm{cd}}$ & $906.2^{\mathrm{de}}$ & $36.45^{\mathrm{ab}}$ \\
\hline & 80 & $46.7^{\text {efgh }}$ & $900.3^{\mathrm{de}}$ & $37.94^{\mathrm{a}}$ \\
\hline & 90 & $47.7^{\mathrm{bc}}$ & $943.0^{\mathrm{cd}}$ & $35.60^{\mathrm{abcd}}$ \\
\hline \multirow{3}{*}{ Phytase C } & 70 & $47.2^{\text {cdef }}$ & $905.9^{\mathrm{de}}$ & $32.28^{\text {cdef }}$ \\
\hline & 80 & $46.5^{\mathrm{gh}}$ & $819.4^{\mathrm{f}}$ & $35.91^{\mathrm{abc}}$ \\
\hline & 90 & $46.6^{\mathrm{fgh}}$ & $808.5^{f}$ & $32.26^{\text {cdefg }}$ \\
\hline \multirow{3}{*}{ Phytase D } & 70 & $47.3^{\text {cde }}$ & $949.3^{\text {bcd }}$ & $37.04^{\mathrm{ab}}$ \\
\hline & 80 & $46.7^{\text {efgh }}$ & $859.4^{\mathrm{ef}}$ & $36.57^{\mathrm{ab}}$ \\
\hline & 90 & $46.2^{\mathrm{h}}$ & $836.9^{f}$ & $31.28^{\text {efg }}$ \\
\hline \multirow{3}{*}{ Positive Control } & 70 & $48.6^{\mathrm{a}}$ & $998.8^{\mathrm{ab}}$ & $28.27^{\mathrm{fg}}$ \\
\hline & 80 & $48.3^{\mathrm{ab}}$ & $981.8^{\mathrm{abc}}$ & $30.22^{\text {efg }}$ \\
\hline & 90 & $49.0^{\mathrm{a}}$ & $1018.4^{\mathrm{a}}$ & $30.33^{\text {efg }}$ \\
\hline \multicolumn{2}{|c|}{ Treatment $P$-value } & $<0.0001$ & $<0.0001$ & $<0.0001$ \\
\hline \multicolumn{2}{|c|}{ Fisher's LSD } & 0.6628 & 53.861 & 4126.5 \\
\hline \multicolumn{2}{|c|}{ Treatment SEM } & 0.237 & 19.278 & 1476.972 \\
\hline \multicolumn{5}{|c|}{ Marginal Means } \\
\hline Phytase A & --- & $47.1^{\mathrm{ab}}$ & $879.4^{\mathrm{b}}$ & $37.91^{\mathrm{a}}$ \\
\hline Phytase B & --- & $47.3^{\mathrm{a}}$ & $916.5^{\mathrm{a}}$ & $36.66^{\mathrm{ab}}$ \\
\hline Phytase C & $\begin{array}{ll}-- \\
--\end{array}$ & $46.8^{\mathrm{b}}$ & $844.6^{\mathrm{c}}$ & $33.48^{\mathrm{c}}$ \\
\hline Phytase D & $\begin{array}{ll}-- \\
--\end{array}$ & $46.7^{\mathrm{b}}$ & $881.9^{\mathrm{b}}$ & $34.96^{\mathrm{bc}}$ \\
\hline \multicolumn{2}{|c|}{ SEM } & 0.139 & 11.671 & 903.653 \\
\hline--- & 70 & $47.3^{\mathrm{a}}$ & $922.2^{\mathrm{a}}$ & $36.03^{\mathrm{ab}}$ \\
\hline $\begin{array}{ll}-- \\
--\end{array}$ & 80 & $46.7^{\mathrm{b}}$ & $858.8^{\mathrm{b}}$ & $37.16^{\mathrm{a}}$ \\
\hline--- & 90 & $46.9^{b}$ & $860.7^{\mathrm{b}}$ & $34.08^{\mathrm{b}}$ \\
\hline \multicolumn{2}{|c|}{ SEM } & 0.121 & 10.107 & 782.586 \\
\hline \multicolumn{5}{|c|}{ Main Effects and Interactions } \\
\hline \multicolumn{2}{|c|}{ Phytase } & 0.0204 & 0.0006 & 0.0047 \\
\hline \multicolumn{2}{|c|}{ Conditioning Temperature } & 0.0033 & $<0.0001$ & 0.0221 \\
\hline \multicolumn{2}{|c|}{ Phytase x Conditioning Temp } & 0.0331 & 0.0142 & 0.4849 \\
\hline
\end{tabular}

${ }^{\mathrm{a}-\mathrm{j}}$ Means within a column not sharing a common superscript differ significantly $(\mathrm{P}<0.05)$. 
Table 6. Pearson correlation coefficients (r; above) and probability values (below) of in vitro phytase activity (FTU/kg) correlated to performance, tibia mineralization, and plasma myo-inositol concentration variables analyzed categorically.

\begin{tabular}{|c|c|c|c|c|c|c|c|c|}
\hline \multirow[b]{2}{*}{ Phytase } & \multicolumn{8}{|c|}{ Correlated to FYT/kg } \\
\hline & $\begin{array}{l}\text { Conditioning } \\
\text { Temperature }\end{array}$ & $\begin{array}{l}\text { Ending Bird } \\
\text { Weight }\end{array}$ & Pen $\mathrm{FI}^{3}$ & FCR & $\begin{array}{c}\text { Bird } \\
\text { LWG }^{4}\end{array}$ & $\begin{array}{l}\text { Tibia Ash } \\
\text { (mg/chick) }\end{array}$ & $\begin{array}{c}\text { Tibia Ash } \\
(\%)\end{array}$ & $\begin{array}{c}\text { Plasma } \\
\text { Myo-inositol }\end{array}$ \\
\hline A & $\begin{array}{c}-0.8077^{1} \\
0.4014^{2}\end{array}$ & $\begin{array}{c}-0.7542 \\
0.4560\end{array}$ & $\begin{array}{c}-0.9999 \\
0.0027\end{array}$ & $\begin{array}{l}-0.8572 \\
0.3444\end{array}$ & $\begin{array}{c}-0.7604 \\
0.4500\end{array}$ & $\begin{array}{l}0.4252 \\
0.7204\end{array}$ & $\begin{array}{c}-0.4977 \\
0.6683\end{array}$ & $\begin{array}{l}0.9768 \\
0.1373\end{array}$ \\
\hline $\mathrm{B}$ & $\begin{array}{c}-0.8779 \\
0.3179 \\
\end{array}$ & $\begin{array}{c}-0.7285 \\
0.4805 \\
\end{array}$ & $\begin{array}{c}-0.9935 \\
0.0724 \\
\end{array}$ & $\begin{array}{l}0.1497 \\
0.9043\end{array}$ & $\begin{array}{c}-0.7231 \\
0.4854\end{array}$ & $\begin{array}{c}-0.9885 \\
0.0967\end{array}$ & $\begin{array}{c}-0.6721 \\
0.5308\end{array}$ & $\begin{array}{l}0.7620 \\
0.4485\end{array}$ \\
\hline $\mathrm{C}$ & $\begin{array}{c}-0.9299 \\
0.2396 \\
\end{array}$ & $\begin{array}{c}-0.4398 \\
0.7101 \\
\end{array}$ & $\begin{array}{c}-0.7640 \\
0.4465 \\
\end{array}$ & $\begin{array}{l}-0.9430 \\
0.2159 \\
\end{array}$ & $\begin{array}{c}-0.4375 \\
0.7118 \\
\end{array}$ & $\begin{array}{l}0.6978 \\
0.5083 \\
\end{array}$ & $\begin{array}{l}0.5474 \\
0.6312 \\
\end{array}$ & $\begin{array}{l}0.3720 \\
0.7573 \\
\end{array}$ \\
\hline $\mathrm{D}$ & $\begin{array}{c}-0.8641 \\
0.3357 \\
\end{array}$ & $\begin{array}{l}0.0160 \\
0.9898\end{array}$ & $\begin{array}{c}-0.7276 \\
0.4813 \\
\end{array}$ & $\begin{array}{l}-0.2126 \\
0.8636\end{array}$ & $\begin{array}{l}0.0158 \\
0.9899\end{array}$ & $\begin{array}{l}0.6516 \\
0.5482\end{array}$ & $\begin{array}{l}0.8514 \\
0.3515\end{array}$ & $\begin{array}{l}0.9970 \\
0.0492\end{array}$ \\
\hline
\end{tabular}

${ }^{1}$ Correlation Coefficients (r; above)

${ }^{2}$ Probability values (below)

${ }^{3} \mathrm{FI}=$ Feed Intake.

${ }^{4} \mathrm{LWG}=$ Live Weight Gain.

Table 7. Pearson correlation coefficients (r; above) and probability values (below) of in vitro phytase activity (FTU/kg) correlated to performance, tibia mineralization, and plasma myo-inositol concentration variables analyzed using replicated data.

\begin{tabular}{|c|c|c|c|c|c|c|c|c|}
\hline \multirow{2}{*}{ Phytase } & \multicolumn{9}{|c|}{ Correlated to FYT/kg } \\
\cline { 2 - 9 } & $\begin{array}{c}\text { Conditioning } \\
\text { Temperature }\end{array}$ & $\begin{array}{c}\text { Ending Bird } \\
\text { Weight }\end{array}$ & Pen FI $^{3}$ & FCR & $\begin{array}{c}\text { Bird } \\
\text { LWG }^{4}\end{array}$ & $\begin{array}{c}\text { Tibia Ash } \\
(\mathrm{mg} / \text { chick })\end{array}$ & $\begin{array}{c}\text { Tibia } \\
\text { Ash }(\%)\end{array}$ & $\begin{array}{c}\text { Plasma } \\
\text { Myo-inositol }\end{array}$ \\
\hline \multirow{2}{*}{ A } & $-0.7628^{1}$ & -0.0516 & -0.1990 & -0.3819 & -0.0504 & 0.0961 & -0.2061 & 0.0285 \\
& $<0.0001^{2}$ & 0.7864 & 0.2919 & 0.0373 & 0.7914 & 0.6134 & 0.2745 & 0.8813 \\
\hline \multirow{2}{*}{ B } & -0.5296 & 0.0918 & -0.0908 & -0.1348 & 0.0891 & -0.0499 & -0.1262 & 0.1512 \\
& 0.0026 & 0.6295 & 0.6333 & 0.4775 & 0.6398 & 0.7932 & 0.5065 & 0.4250 \\
\hline \multirow{2}{*}{ C } & -0.8602 & -0.1103 & -0.2188 & -0.3413 & -0.1102 & 0.4622 & 0.1863 & -0.0521 \\
& $<0.0001$ & 0.5619 & 0.2455 & 0.0649 & 0.5622 & 0.0101 & 0.3243 & 0.7846 \\
\hline \multirow{2}{*}{ D } & -0.7051 & -0.1461 & -0.1772 & -0.0094 & -0.1441 & 0.2621 & 0.2549 & 0.2708 \\
& $<0.0001$ & 0.4412 & 0.3490 & 0.9605 & 0.4473 & 0.1617 & 0.1741 & 0.1478 \\
\hline
\end{tabular}

${ }^{1}$ Correlation Coefficients (r; above)

${ }^{2}$ Probability values (below)

${ }^{3} \mathrm{FI}=$ Feed Intake.

${ }^{4} \mathrm{LWG}=$ Live Weight Gain. 


\title{
CHAPTER 4
}

\section{Energy releasing efficacy of graded levels of a commercial microbial phytase}

\author{
A. E. Lamp* and J. S. Moritz*1 \\ *Division of Animal and Nutritional Sciences, West Virginia University, Morgantown, \\ West Virginia, 26506 \\ Phone: 304-293-1911
}

Fax: 304-293-2232

${ }^{1}$ Corresponding Author: Joe.Moritz@mail.wvu.edu

Primary Audience: Feed Manufactures, Nutritionists, Researches 


\section{SUMMARY}

An experiment was conducted to determine the ME release of a commercial phytase fed to broilers at multiple doses in basal diets that varied in ME. Dietary treatments included three negative controls (NC; $0.75 \%$ calcium and $0.30 \%$ non-phytate phosphorus) formulated at three ME levels $(2701,2868$, and $3000 \mathrm{kcal} / \mathrm{kg})$. A commercial phytase product was added to each NC diet at $1500,4500,13500$, and $30000 \mathrm{FTU} / \mathrm{kg}$, creating a total of 15 dietary treatments. Treatments were arranged in a 5 (phytase dose) x 3 (ME level) factorial in a randomized complete block design with nine replications of ten male broilers fed each of 15 dietary treatments for 21 days. Alpha was designated as 0.05 for significance and 0.10 for trending data. For all measurement periods (d7, 14, and 21), FCR decreased as ME increased $(\mathrm{P}<0.0001)$. On d21, ending bird weight and live weight gain (LWG) increased with the addition of phytase and as $\mathrm{ME}$ increased $(\mathrm{P}<0.05)$. Furthermore, the addition of phytase significantly improved $\mathrm{d} 14$ and 21 FCR $(\mathrm{P}<0.05)$. Trends were observed for ME level $\mathrm{x}$ phytase dose interactions for $\mathrm{d} 41$ and 21 FCR. These trends demonstrate that phytase is most beneficial with the low energy diets. Eight treatments were selected for AMEn analysis based on d14 and 21 FCR data; AMEn ranged from 2773 to $3457 \mathrm{kcal} / \mathrm{kg}$. Diets formulated at $2701 \mathrm{kcal} / \mathrm{kg}$ dosed at 1500,13500 , and 30000 FTU $/ \mathrm{kg}$ released $114,-179$, and $-2.76 \mathrm{kcal} / \mathrm{kg}$, respectively. Whereas, diets formulated at 2868 $\mathrm{kcal} / \mathrm{kg}$ dosed at 1500 and $13500 \mathrm{FTU} / \mathrm{kg}$ released 281 and $423 \mathrm{kcal} / \mathrm{kg}$, respectively. Contrary to past studies, clear results were not observed for the energy releasing efficacy of graded levels of phytase. Performance improvements with phytase supplementation were likely more associated with P availability than AMEn availability.

Key words: phytase, nitrogen-corrected apparent metabolizable energy, phytase dose, broiler, metabolizable energy level 


\section{DESCRIPTION OF PROBLEM}

Phytate forms chelates with nutrients such as amino acids and energy in the form of mucins and has the potential to chelate with cations such as $\mathrm{Ca}, \mathrm{Cu}, \mathrm{Zn}, \mathrm{Mn}, \mathrm{Mg}$, and $\mathrm{Fe}$, rendering them unavailable (Vohra et al., 1965; Cosgrove, 1980; Maga, 1983; Anderson, 1985; Morris, 1986; Lott et al., 2000; Kleyn, 2013; Cowieson et al., 2016). Therefore, the hydrolysis of phytate may not only release phosphorus $(\mathbf{P})$, but minerals, amino acids, and energy may be released as well. Several scientists have researched these benefits of phytase and found that phytase supplementation increased AME by an average of $86.98 \mathrm{kcal} / \mathrm{kg}(2.8 \%)$ over nonsupplemented controls fed to broilers (Driver et al., 2006; Farrell et al., 1993; Kocher et al., 2003; Namkung and Leeson, 1999; Shirley and Edwards, 2003).

Typically, suppliers of commercial phytase recommend supplementation between 500 and 1,000 FTU/kg; therefore, inclusions greater than 1,500 FTU/kg are considered super-dosing (Boney and Moritz, 2017). Nelson and cohorts (1971) were the earliest to report super-dosing effects of an Aspergillus ficuum phytase dosed in feed between 950 and 7,600 FTU/kg. These scientists observed an apparent phytate-P disappearance of 38.9 and 94.4\%, respectively. Shirley and Edwards (2003) fed a corn-soybean meal based diet supplemented with graded levels of Natuphos 5000 to broilers for 16 days. Their research concluded that supplementing phytase from 0 to 12,000 U/kg significantly increased body weight gain, feed intake (FI), gain to feed, phytate P disappearance from $40 \%$ to $95 \%$, apparent nitrogen (N) retention from 58 to $78 \%$, and AMEn from 3,216 to 3,415 kcal/kg diet. Another scientist also observed an AMEn increase with graded levels of phytase. Coelho and cohorts (2019b) conducted a study examining ME releasing efficacy of graded levels of Natuphos E in 28-d old broilers fed a pelleted corn, soybean meal, and DDGS diet. Natuphos E was dosed at 0, 250, 500, 750, 1000, 2000, and 3000 FTU/kg. Total 
tract AME digestibility was determined to be $2865,2918,2944,2957,2984,3048$, and 3151

$\mathrm{kcal} / \mathrm{kg}$, respectively $(\mathrm{P}=0.02)$. Their research concluded that phytase released 53, 79, 92, 119, 183 , and $286 \mathrm{kcal} / \mathrm{kg}$, respectively $(\mathrm{P}=0.03)$. A similar study performed by Coelho and others (2019a) demonstrated that 28-d old broilers fed a mash diet supplemented with $0,1000,1500$, 2000, 2500, and $3000 \mathrm{FTU} / \mathrm{kg}$ of Natuphos E released 79, 125, 154, 199, and $257 \mathrm{kcal} / \mathrm{kg}$, respectively. Apparent metabolizable energy was calculated to be 2932, 3011, 3057, 3086, 3131, and $3189 \mathrm{kcal} / \mathrm{kg}$, respectively. Therefore, the current study hypothesized that the ME releasing efficacy of phytase fed at 1500, 4500, 13500, and 30000 will increase as phytase dose increases. The objective of the study was to feed broilers diets that differed in $\operatorname{ME}(2701,2868$, and 3000 $\mathrm{kcal} / \mathrm{kg}$ ) and graded levels of a microbial phytase and determine ME releasing efficacy.

\section{MATERIALS AND METHODS}

\section{Diet Formulation and Dietary Treatments}

Diets were corn and soybean meal based containing 5\% DDGS and were formulated to contain similar calculated nutrient values that were based on commercial (Donohue, 2013) and research guidelines (Tillman and Dozier, 2013) (Table 1). A total of five phytase enzyme doses and three ME levels were utilized for this experiment, creating a total of 15 dietary treatments. The commercial phytase product utilized was a phytase sourced from an Escherichia coli species bacterium expressed in a Trichoderma reesei fungus with a suggested $\mathrm{P}$ and $\mathrm{Ca}$ sparing effect of 0.15 and $0.16 \%$, respectively (AB Vista, Plantation, FL). Therefore, the three negative controls (NC) were formulated with reduced calcium $(\mathbf{C a})(0.75 \%)$ and non-phytate phosphorus (nPP) $(0.3 \%)$. Additionally, to observe benefits of nutrient sparing, each NC diet was formulated to a different ME level: NC1 (2701 kcal/kg), NC2 (2868 kcal/kg), and NC3 (3000 kcal/kg). The remaining 12 diet formulations were created by top dressing a commercial phytase product to 
each of the NC diets. The five phytase doses were $\mathbf{0}, \mathbf{1 5 0 0}, \mathbf{4 5 0 0}, \mathbf{1 3 5 0 0}$, and $30000 \mathrm{FTU} / \mathrm{kg}$. One phytase unit (FTU) is defined as the amount of enzyme required to release $1 \mu \mathrm{mol}$ of inorganic phosphate per minute from a $5.1 \mathrm{~m} M$ sodium phytate at $\mathrm{pH} 5.5$ and $37^{\circ} \mathrm{C}$. (Engelen et al., 2001).

\section{Feed Manufacture}

All feed was manufactured at the West Virginia University (WVU) pilot feed mill. Three master batches of $860 \mathrm{~kg}$ were mixed for 10 minutes in a one-ton vertical screw Modular Feed Processor Vertical Mixer (Model MFP SKI, Easy Automation Inc., Welcome, MN) without soybean oil, sand, or phytase and split into three allotments containing $830 \mathrm{~kg}$ each. Washed builders sand was used to standardize volume among the different soybean oil inclusions to a $3.50 \%$ total inclusion. Titanium (Ti) dioxide $(0.2 \%)$ was utilized as an indigestible marker for AMEn determination. According to diet formulation (ME level), sand, soybean oil, and one of the $830 \mathrm{~kg}$ batches were mixed for an additional 10 minutes and split into five $136 \mathrm{~kg}$ allotments. According to diet formulation, phytase and one of the $136 \mathrm{~kg}$ allotments was mixed for $10 \mathrm{~min}$ in a $136 \mathrm{~kg}$ mixer. This process was done for all 15 dietary treatments. Multiple mash samples of each treatment were collected, pooled, and sent to a commercial laboratory for nutrient, Ti, and phytase analysis (AOAC International, 2000; Method 2000.12) (ATC Scientific, North Little Rock, AR) (Table 2).

\section{Live Bird Performance}

A total of one thousand three hundred fifty 1-day-old male Hubbard x Ross 708 (Hubbard LLC, Pikeville, TN; Aviagen, Inc., Huntsville, AL) chicks were obtained from a commercial hatchery (Longeneckers Hatchery, Elizabethtown, PA). On d 1, the chicks were weighed, 10 birds at a time, and were allocated to 135 raised wire cages based on weight to create uniform 
initial pen weights. One of the 15 dietary treatments was randomly assigned to each pen within a block. A block consisted of 15 adjacent cages, and there were 9 blocks or replications per treatment. Chicks were housed in raised wire cages in a cross-ventilated, negative-pressure room. Three identical rooms were utilized; each containing 48 cages, creating a total of 135 cages. Feed was placed in external feed troughs and water was supplied through a nipple drinker system; both feed and water were provided for ad libitum consumption. Room temperature for the 1-dayold chicks was set at $32^{\circ} \mathrm{C}$, and gradually decreased to $29^{\circ} \mathrm{C}$ for the second week and $26^{\circ} \mathrm{C}$ for the third week of the study to create optimal rearing conditions. From d 1 to 6 birds were exposed to $24 \mathrm{~h}$ light, and after $\mathrm{d} 6$, the hours of light were decreased gradually until $6 \mathrm{~h}$ dark was reached on $\mathrm{d} 21$.

The study period was a total of 21 days, and performance measurements were taken on d7, 14, and 21. Measured variables associated with performance included: starting pen weight, d7, 14, and 21 ending bird weight, pen FI, mortality corrected FCR, bird live weight gain (LWG), and pen percent mortality. All animals were reared according to protocols approved by West Virginia University Animal Care and Use Committee.

\section{Nitrogen-Corrected Apparent Metabolizable Energy (AMEn)}

On $\mathrm{d} 21$, birds were exposed to $6 \mathrm{~h}$ dark and then allowed to consume feed for $6 \mathrm{~h}$ to ensure that digesta was present in the digestive tract to perform ileal collection. On d 21, all birds were euthanized via cervical dislocation to determine AMEn. The ileum (defined as the portion of the small intestine extending from the Meckel's diverticulum to the ileal-cecal junction) was excised from each bird (Ravindran et al., 1999). This section was cut in half and the lower section was used for collection. The lower ileum was gently flushed with distilled water, and the digesta washing was collected. The collected digesta was pooled per pen and lyophilized at 
$-40^{\circ} \mathrm{C}$ until dry. (Evans et al., 2015). Digesta samples were sent to a commercial laboratory for Ti, gross energy (GE), and N analysis (ATC Scientific, North Little Rock, AR).

Nitrogen-corrected apparent metabolizable energy and $\mathrm{N}$ retention were determined according to the calculation outlined by Hill and Anderson (1958):

$\mathrm{N}$ retained $(\mathrm{g})=N_{\text {Diet }}-N_{\text {Digesta }}\left(\frac{T i_{\text {Diet }}}{T i_{\text {Digesta }}}\right)$

Where Ti $i_{\text {Digesta }}$ and $\mathrm{Ti}_{\text {Diet }}$ are the analyzed concentrations of $\mathrm{Ti}(\mathrm{g})$ in the digesta and diets, respectively, and $\mathrm{N}_{\text {Digesta }}$ and $\mathrm{N}_{\text {Diet }}$ are the $\mathrm{N}$ (g) content of the digesta and diets, respectively.

$\operatorname{AMEn}(\mathrm{kcal} / \mathrm{g})=G E_{\text {Diet }}-\left[G E_{\text {Digesta }}\left(\frac{T i_{\text {Diet }}}{T i_{\text {Digesta }}}\right)\right]-8.22 \times \mathrm{N}$ retained

Where $\mathrm{GE}_{\text {Digesta }}$ and $\mathrm{GE}_{\text {Diet }}(\mathrm{kcal} / \mathrm{g})$ are the GE content of the digesta and diets, respectively.

\section{Statistical Analysis}

An overall comparison of all fifteen treatments was conducted using ANOVA. A 5 (phytase dose) $\times 3$ (ME level) factorial in a randomized complete block design was used to explore main effects and interactions. The experimental unit was a pen of 10 male broilers. Pen location within the room was used as blocking criterion, and all data were analyzed using the GLM procedure of SAS (SAS Institute, 2013). Means were further explored using Fischer's LSD test when the main effect interaction was significant. Alpha was designated as 0.05 for significance and 0.10 for trending data, and letter superscripts were used to denote differences among treatment means.

\section{RESULTS AND DISSCUSSION}

\section{Dietary Treatments}

A cursory discussion of descriptive analyzed nutrients of each treatment may be useful when considering treatment affects (Table 2). The three NCs were formulated to $22 \% \mathrm{CP}$ and reduced $\mathrm{Ca}(0.75 \%)$ and $\mathrm{nPP}(0.3 \%)$ due to the suggested $\mathrm{Ca}$ and $\mathrm{P}$ sparing associated with the 
commercial phytase, which was considered during diet formulation. Additionally, to observe benefits of nutrient sparing, each NC diet was formulated to a different ME level: 2701, 2868, and $3000 \mathrm{kcal} / \mathrm{kg}$. Crude protein of the treatments ranged from 23.1 to $25.1 \%$, Ca ranged from 0.75 to $0.92 \%$, nPP ranged from 0.36 to $0.52 \%$, and GE ranged from 3587 to $4232 \mathrm{kcal} / \mathrm{kg}$. These differences likely reflect analytical variation since basal formulations were similar.

\section{Live Bird Performance}

Factorial. On d7, the main effect phytase dose was significant for ending bird weight, LWG, and FCR. Birds fed 30000 had the highest d7 ending bird weight and bird LWG; 4500 and 13500 fed birds were intermediate, and birds provided 0 and 1500 had the lowest $(\mathrm{P}<0.05)$ (Table 3). Birds fed 30000 had the lowest d7 FCR; 13500 fed birds were intermediate, and birds provided 0,1500 , and 4500 had the highest FCR $(\mathrm{P}=0.0040)$. For all measurement periods, significant differences were observed for the main effect ME level for pen FI and FCR. Birds provided NC3 had the lowest pen FI, and birds provided NC1 and 2 had the highest $(\mathrm{P}<0.001)$. Feed conversion ratio decreased as ME increased $(\mathrm{P}<0.0001)$.

On d14, both main effects ME level and phytase dose were significant for ending bird weight and bird LWG. Birds provided NC2 and 3 had the highest d14 ending bird weight and bird LWG, and birds provided NC1 had the lowest $(\mathrm{P}<0.05)$. Birds fed 30000 had the highest d14 ending bird weight and bird LWG; 1500, 4500, and 13500 fed birds were intermediate, and birds provided 0 had the lowest $(\mathrm{P}=0.0008)$. Significant differences were observed for the main effect phytase dose for d14 pen FI and FCR. Birds fed 30000 had the highest pen FI; 1500, 4500, and 13500 fed birds were intermediate, and birds provided 0 had the lowest $(\mathrm{P}=0.0106)$. For FCR, birds fed 13500 had the lowest d14 FCR; 1500, 4500, and 30000 fed birds were intermediate, and birds provided 0 had the highest $(\mathrm{P}<0.0001)$. Negative control 213500 
released the most energy ( $423 \mathrm{kcal} / \mathrm{kg}$ ) compared to other doses; therefore, this may have contributed to the deceased FCR. Similar results were observed by Shirley and Edwards (2003) who supplemented a corn-soybean meal based diet with Natuphos 5000 at $0,93.75,187.5,375$, $750,1,500,3,000,6,000$, or 12,000 . U/kg diet. The basal diet contained an analyzed $22.2 \% \mathrm{CP}$, $0.88 \% \mathrm{Ca}, 0.27 \% \mathrm{nPP}$, and calculated ME of $3.123 \mathrm{kcal} / \mathrm{g}$ and was fed to broilers for 16 days. Their results demonstrated that phytase supplementation reduced FCR compared to no supplementation $(\mathrm{P}<0.05)$. In the current study, the main effect ME level was significant for mortality, demonstrating that birds fed 0 had the highest d14 mortality, and all other treatments had the lowest $(\mathrm{P}=0.0033)$.

On $\mathrm{d} 21$, the main effects phytase dose and ME level were significant for ending bird weight and bird LWG; ending bird weight and LWG increased with the addition of phytase and as ME increased $(\mathrm{P}<0.05)$ (Table 4). Significant differences were observed for the main effect phytase dose for d21 pen FI and FCR. Birds fed 13500 and 30000 had the highest pen FI; 1500 and 4500 fed birds were intermediate, and birds provided 0 had the lowest $(\mathrm{P}=0.0248)$. The addition of phytase decreased $\mathrm{d} 21 \mathrm{FCR}(\mathrm{P}=0.0001)$. Trends were observed for ME level $\mathrm{x}$ phytase dose interactions for $\mathrm{d} 41$ and $21 \mathrm{FCR}$. These trends demonstrate that phytase is most beneficial with the low energy diets. The authors speculate that perhaps birds fed the low energy diets have the most potential to benefit from increased P availability because they are so nutritionally deficient or the fact that they had increased FI.

Overall comparison. Birds provided NC 230000 had the highest d7 and 14 pen FI; birds provided NC3 4500 had the lowest, and all other treatments were intermediate $(\mathrm{P}<0.01)$ (Table 3). Negative Control 330000 fed birds had the lowest d7 FCR, and birds provided NC1 1500 and 4500 had the highest; all other treatment were intermediate $(\mathrm{P}<0.0001)$. All performance 
metrics measured on d14 were significant for the overall comparison of all fifteen treatments ( $\mathrm{P}$ $<0.05$ ). Birds provided NC 230000 had the highest d14 ending bird weight and subsequent LWG, and NC1 0 and NC2 0 fed birds had the lowest; all other treatments were intermediate (P $=0.0011)$. Birds fed NC3 4500 and 30000 had the lowest $\mathrm{d} 14$ and $21 \mathrm{FCR}$, and birds provided NC1 0 had the highest; all other treatment were intermediate $(\mathrm{P}<0.0001)$. Negative Control 20 fed birds had the highest d14 mortality; NC1 0 and NC3 4500 fed birds were intermediate, and all other treatments had the lowest mortality $(\mathrm{P}=0.0152)$. Negative Control 313500 fed birds had the highest $\mathrm{d} 21$ ending bird weight and subsequent LWG, and NC1 0 fed birds had the lowest; all other treatments were intermediate $(\mathrm{P}<0.0001)$ (Table 4). Similar to $\mathrm{d} 7$ and 14 , birds provided NC 230000 had the highest d21 pen FI; birds provided NC3 0 and 4500 had the lowest, and all other treatments were intermediate $(\mathrm{P}<0.0001)$.

\section{Nitrogen-Corrected Apparent Metabolizable Energy (AMEn)}

Eight treatments were selected for AMEn analysis. The treatments selected where the three controls ( $\mathrm{NC1}$ 0, NC2 0, and NC3 0), NC1 1500, 13500, and 30000, and NC2 1500 and 13500. These treatments were selected utilizing $\mathrm{d} 14$ and $21 \mathrm{FCR}$ data. Treatments selected that included phytase statistically differed in FCR to their respective control (treatments not containing phytase); proving that phytase inclusion improved FCR. Nitrogen-corrected apparent metabolizable energy was 2952, 3457, 3324, 3001, 2773, 2949, 3176, and $3034 \mathrm{kcal} / \mathrm{kg}$, respectively $(\mathrm{P}<0.0001)$ (Table 4). Diets formulated at $2701 \mathrm{kcal} / \mathrm{kg}$ dosed at 1500,13500 , and $30000 \mathrm{FTU} / \mathrm{kg}$ released $114,-179$, and $-2.76 \mathrm{kcal} / \mathrm{kg}$, respectively. Whereas, diets formulated at $2868 \mathrm{kcal} / \mathrm{kg}$ dosed at 1500 and $13500 \mathrm{FTU} / \mathrm{kg}$ released 281 and $423 \mathrm{kcal} / \mathrm{kg}$, respectively.

Coelho and cohorts (2019b) conducted a study examining ME releasing efficacy of graded levels of Natuphos E in 28-d old broilers fed a corn, soybean meal, and DDGS diet. There 
was a $300 \mathrm{kcal} / \mathrm{kg}, 0.17 \% \mathrm{Ca}$, and $0.15 \% \mathrm{nPP}$ decrease in the $\mathrm{NC}$ diet compared to the positive control (PC). Natuphos E was dosed at 0, 250, 500, 750, 1000, 2000, and $3000 \mathrm{FTU} / \mathrm{kg}$. Total tract AME digestibility increased from 2865 to $3151 \mathrm{kcal} / \mathrm{kg}$ as enzyme dosed increased $(\mathrm{P}=$ 0.02). Their research concluded that phytase released 53, 79, 92, 119, 183, and $286 \mathrm{kcal} / \mathrm{kg}$, respectively $(\mathrm{P}=0.03)$. A second study by Coelho and others (2019a) demonstrated that 0,1000 , $1500,2000,2500$, and $3000 \mathrm{FTU} / \mathrm{kg}$ of Natuphos E fed to 28 -d old broilers released 79, 125, 154, 199, and $257 \mathrm{kcal} / \mathrm{kg}$, respectively. Apparent metabolizable energy increased from 2932 to $3189 \mathrm{kcal} / \mathrm{kg}$ as enzyme dosed increased. Nitrogen-corrected apparent metabolizable energy for the current study ranged from 2773 to $3457 \mathrm{kcal} / \mathrm{kg}$; however, AMEn did not increase as phytase dose increased. In the current study, NC1 1500 fed birds had a AMEn of $3001 \mathrm{kcal} / \mathrm{kg}$ and 114 $\mathrm{kcal} / \mathrm{kg}$ was released. These results are similar to Coelho and cohorts (2019b) who observed an AMEn of $2984 \mathrm{kcal} / \mathrm{kg}$ and a release of $119 \mathrm{kcal} / \mathrm{kg}$ when the diet was supplemented with 1000 FTU/kg. Past and current research has proven the benefits of super-dosing and the additional benefit of energy release from phytase supplementation. This research will ultimately lead to a more precise matrix for phytase in the case of diet formulation in the poultry industry. The current study's phytase benefits in LWG and FCR were likely associated with increased P availability rather than increased AMEn, since AMEn benefit could not be consistently determined.

\section{CONCLUSION AND APPLICATIONS}

1. For all measurement periods, birds provided NC3 $(3000 \mathrm{kcal} / \mathrm{kg})$ had the lowest pen FI, and birds provided NC1 $(2701 \mathrm{kcal} / \mathrm{kg})$ and $2(2868 \mathrm{kcal} / \mathrm{kg})$ had the highest $(\mathrm{P}<0.001)$. Additionally, FCR decreased as ME increased $(\mathrm{P}<0.0001)$. 
2. On $\mathrm{d} 21$, ending bird weight and LWG increased with the addition of phytase and as ME increased $(\mathrm{P}<0.05)$. Birds fed 13500 and 30000 had the highest pen FI; 1500 and 4500 fed birds were intermediate, and birds provided 0 had the lowest $(\mathrm{P}=0.0248)$. The addition of phytase significantly improved d14 and 21 FCR $(\mathrm{P}<0.05)$. Trends were observed for ME level x phytase dose interactions for d41 and 21 FCR. These trends demonstrate that phytase is most beneficial with the low energy diets.

3. Nitrogen-corrected apparent metabolizable energy for the current study ranged from 2773 to $3457 \mathrm{kcal} / \mathrm{kg}$; however, AMEn did not increase as phytase dose increased.

4. Diets formulated at $2701 \mathrm{kcal} / \mathrm{kg}$ dosed at 1500,13500 , and $30000 \mathrm{FTU} / \mathrm{kg}$ released 114 , -179 , and $-2.76 \mathrm{kcal} / \mathrm{kg}$, respectively. Whereas, diets formulated at $2868 \mathrm{kcal} / \mathrm{kg}$ dosed at 1500 and $13500 \mathrm{FTU} / \mathrm{kg}$ released 281 and $423 \mathrm{kcal} / \mathrm{kg}$, respectively.

5. Contrary to past studies, clear results were not observed for the energy releasing efficacy of graded levels of phytase. Performance improvements with phytase supplementation were likely more associated with P availability than AMEn availability.

\section{REFERENCES AND NOTES}

Anderson, P. A. 1985. Interactions between proteins and constituents that affect protein quality. Pages 31-46 in: Digestibility and Amino Acid Availability in Cereals and Oilseeds. G.W. Finley and D. T. Hopkins, ed. American Association of Cereal Chemists, St. Paul, MN. AOAC International. 2000. Official Methods of Analysis of the AOAC International, 17th ed., Gaithersburg, MD.

Boney J. W. and J.S. Moritz. 2017. Phytase dose effects in practically formulated diets that vary in ingredient composition on feed manufacturing and broiler performance. Journal of Applied Poultry Research. 26: 273-285. 
Coelho, M., R. Jones, F. Parks. 2019a. Energy (ME)-releasing efficacy of graded levels of 6phytase, Natuphos E, NSPase, Natugrain TS, and a combination of phytase + NSPase in 28-day old broilers fed corn/soy/DDGs diet. Poult. Sci. Vol. 98 (Suppl. 1): 336.

Coelho, M., R. Jones, F. Parks. 2019b. Energy (ME) and amino acid releasing efficacy of graded levels of 6-phytase, Natuphos E, in 28 day old broilers fed a corn/soy/DDGs diet. Poult. Sci. Vol. 98 (Suppl. 1): 342.

Cosgrove, D. J. 1980. Inositol Phosphates: Their Chemistry, Biochemistry and Physiology. Elsevier Scientific Publishing Co., New York, NY.

Cowieson, A. J., P. Wilcocock, and M. R. Bedford. 2011. Super-dosing effects of phytase in 435 poultry and other monogastrics. World's Poult. Sci. J. 67:225-235.

Cowieson, A. J., J. P. Ruckebusch, I. Knap, P. Guggenbuhl, F. Fru-Nji. 2016. Phytate-free nutrition: A new paradigm in monogastric animal production. Animal Feed Science and Technology. Volume 2220: 180-189.

Donohue. M. 2013. The Challenges in Feeding Broilers in Times of High and Volatile Feed Ingredient Costs: How to Cover the Costs? 2013 Mid-Atlantic Nutrition Conference proceedings.

Driver, J. P., A. Antencio, H. M. Edwards, and G. M. Pesti. 2006. Improvements in nitrogencorrected apparent metabolizable energy of peanut meal in response to phytase supplementation. Poult. Sci. 85:96-99.

Engelen, A. J., F. C. van der Heeft, P. H. G. Randsdorp, W. A. C. Somers, J. Schaefer, and B. J. C. van der Vat. 2001. Determination of phytase activity in feed by a colorimetric enzymatic method: Collaboration interlaboratory study. J. AOAC Int. 84:629-633. 
Evans, A. M., D.L. Smith, and J.S. Moritz. 2015. Effects of algae incorporation into broiler starter diet formulations on nutrient digestibility and 3 to $21 \mathrm{~d}$ bird performance. J. Appl. Poult. Res. 24:206-214.

Farrell, D. J., E. Martin, J. J. du Preez, M. Bongarts, M. Betts, A. Sudaman, and E. Thomson. The beneficial effects of a microbial phytase in diets of broiler chickens and ducklings. J. Anim. Physiol. Anim. Nutr. 69:278-283.

Hill, F. W. and D. L. Anderson. 1958. Comparison of metabolizable energy and productive energy determinations with growing chicks. J. of Nutrition. 64:587-603.

Kocher, A., M. Choct, G. Ross, and T. K. Chung. 2003. Effects of phytase on apparent metabolizable energy in broiler diets based on wheat or sorghum. Proc. Aust. Poult. Sci. Symp. 15, 112.

Kleyn, R. 2013. Minerals. Pages 69-72 in Chicken Nutrition: A Guide for Nutritionists 388 and Poultry Professionals. British library press, Leicestershire, London, UK.

Lott, J. N. A., I. Ockenden, V. Raboy, and G. D. Batten. 2000. Phytic acid and phosphorus in crop seeds and fruits: a global estimate. Seed Science Research. 10: 11-33.

Maga, J. A. 1983. Phytate: its occurrence, food interactions, nutritional significance and methods of analysis. J. Agric. Food Chem. 30, 1-9.

Morris, E. R. 1986. Phytate and dietary mineral bioavailability. Pages 57-76 in: Phytic Acid: Chemistry and Applications. E. Grad, ed. Pilatus Press, Minneapolis, MN.

Namkung, H. and S. Leeson. 1999. Effect of phytase enzyme on dietary nitrogen-corrected apparent metabolizable energy and the ileal digestibility of nitrogen and amino acids. Poult. Sci. 78: 1317-1319. 
Nelson, T. S., T. R. Shieh, R. J. Wodzinski, and J. H. Ware. 1971. Effect of supplemental phytase on the utilization of phytate phosphorus by chicks. Journal of Nutrition 101: 1289-1294.

Ravindran, V., L. I. Hew, G. Ravindran, and W. L. Bryden. 1999. A comparison of ileal digesta and excreta analysis for the determination of amino acid digestibility in food ingredients for poultry. Br. Poult. Sci. 40:266-274.

SAS Institute. 2013. The SAS system for Windows 2013. Release 9.3 SAS Inst. Inc., Cary, NC.

Shirley, R.B and H. M. Edwards. 2003. Graded levels of phytase past industry standards improves broiler performance. Poult. Sci. 82: 671-680.

Tillman, P. B. and W.A. Dozier. 2013. Current Amino Acid Considerations for Broilers: Requirements, Ratios, Economics for 8 - 14 day broilers. www.thepoultryfederation.com.

Vohra, P., G. A. Gray, and F. H. Kratzer. 1965. Phytic acid-metal complexes. Proc. Soc. Exp. Biol. Med. 120:447-449. 
Table 1. Diet composition and nutrient specifications ${ }^{1,2}$ of the negative control diets provided during the trial.

\begin{tabular}{|l|c|c|c|}
\hline \multicolumn{1}{|c|}{ Ingredients } & Negative Control 1 & Negative Control 2 & Negative Control 3 \\
\hline & \multicolumn{2}{|c|}{ Inclusion (\%) } \\
\hline Corn & 50.16 & 50.16 & 50.16 \\
\hline Soybean meal (48\%) & 37.68 & 37.68 & 37.68 \\
\hline Corn DDGS & 5.00 & 5.00 & 5.00 \\
\hline Soybean oil & 0.29 & 2.09 & 3.50 \\
\hline Sand & 3.21 & 1.41 & --- \\
\hline Dicalcium P & 1.23 & 1.23 & 1.23 \\
\hline Limestone & 0.96 & 0.96 & 0.96 \\
\hline DL- methionine & 0.47 & 0.47 & 0.47 \\
\hline Salt & 0.27 & 0.27 & 0.27 \\
\hline Threonine & 0.27 & 0.27 & 0.27 \\
\hline Vitamin/mineral premix ${ }^{3}$ & 0.25 & 0.25 & 0.25 \\
\hline Lysine & 0.11 & 0.11 & 0.11 \\
\hline Sodium bicarbonate & 0.10 & 0.10 & 0.10 \\
\hline \multicolumn{2}{|c|}{ Calculated Nutrients $(\%)$} & & 3000 \\
\hline ME (kcal/kg) & 2701 & 2868 & 22.0 \\
\hline Crude Protein & 22.0 & 22.0 & 1.20 \\
\hline Digestible Lysine & 1.20 & 1.20 & 1.09 \\
\hline Digestible Methionine and Cysteine & 1.09 & 1.09 & 0.79 \\
\hline Digestible Methionine & 0.79 & 0.79 & 1.01 \\
\hline Digestible Threonine & 1.01 & 1.01 & 0.24 \\
\hline Digestible Tryptophan & 0.24 & 0.24 & 0.75 \\
\hline Calcium & 0.75 & 0.75 & 0.30 \\
\hline nPP & 0.30 & 0.30 & 0.17 \\
\hline Sodium & 0.17 & 0.17 & \\
\hline
\end{tabular}

${ }^{1}$ Available Phosphorus were based on Agristat values, as suggested by Donohue (2013).

${ }^{2}$ Digestible amino acids were based on values suggested by Tillman and Dozier (2013).

${ }^{3}$ Vitamin mineral premix (NB3000, Nutrablend, Neosho, MO) supplied the following per $\mathrm{kg}$ of diet: manganese, $0.02 \mathrm{mg}$; zinc, $0.02 \mathrm{mg}$; iron, $0.01 \mathrm{mg}$; copper, $0.0025 \mathrm{mg}$; iodine, $0.0003 \mathrm{mg}$; selenium, $0.00003 \mathrm{mg}$; folic acid, $0.69 \mathrm{mg}$; choline, $386 \mathrm{mg}$; riboflavin, $6.61 \mathrm{mg}$; biotin, $0.03 \mathrm{mg}$; vitamin B6, $1.38 \mathrm{mg}$; niacin, $27.56 \mathrm{mg}$; pantothenic acid, $6.61 \mathrm{mg}$; thiamine, $2.20 \mathrm{mg}$; menadione, $0.83 \mathrm{mg}$; vitamin B12, $0.01 \mathrm{mg}$; vitamin E, $16.53 \mathrm{IU}$; vitamin D3, 2,133 ICU; vitamin A, 7,716 IU. 
Table 2. Analyzed nutrients and descriptive in vitro phytase activity of diets provided to broilers from d1-21.

\begin{tabular}{|c|c|c|c|c|c|c|c|}
\hline $\begin{array}{l}\text { ME Level } \\
(\mathrm{kcal} / \mathrm{kg})\end{array}$ & $\begin{array}{c}\text { Phytase Dose } \\
\text { (FTU/kg) }\end{array}$ & $\begin{array}{c}\text { Crude } \\
\text { Protein }^{1}(\%)\end{array}$ & Calcium $^{2}(\%)$ & Phosphorus $^{3}(\%)$ & $\mathrm{nPP}^{4}(\%)$ & Nitrogen $^{5}(\%)$ & $\begin{array}{c}\text { Gross Energy } \\
(\mathrm{kcal} / \mathrm{kg})\end{array}$ \\
\hline \multirow{5}{*}{2701} & 0 & 24.2 & 0.81 & 0.66 & 0.36 & 3.88 & 3760 \\
\hline & 1500 & 24.3 & 0.83 & 0.66 & 0.39 & 3.90 & 3829 \\
\hline & 4500 & 24.3 & 0.81 & 0.68 & 0.40 & 3.89 & 3587 \\
\hline & 13500 & 23.1 & 0.90 & 0.68 & 0.40 & 3.69 & 3951 \\
\hline & 30000 & 23.6 & 0.92 & 0.75 & 0.52 & 3.78 & 3644 \\
\hline \multirow{5}{*}{2868} & 0 & 24.8 & 0.84 & 0.68 & 0.39 & 3.96 & 4210 \\
\hline & 1500 & 24.7 & 0.75 & 0.66 & 0.38 & 3.96 & 3874 \\
\hline & 4500 & 24.1 & 0.90 & 0.71 & 0.43 & 3.85 & 3909 \\
\hline & 13500 & 23.9 & 0.89 & 0.69 & 0.40 & 3.83 & 3915 \\
\hline & 30000 & 24.2 & 0.89 & 0.68 & 0.43 & 3.86 & 3612 \\
\hline \multirow{5}{*}{3000} & 0 & 24.9 & 0.82 & 0.64 & 0.36 & 3.98 & 4110 \\
\hline & 1500 & 25.0 & 0.75 & 0.64 & 0.36 & 3.99 & 4029 \\
\hline & 4500 & 25.0 & 0.81 & 0.67 & 0.38 & 4.00 & 3926 \\
\hline & 13500 & 24.1 & 0.86 & 0.65 & 0.36 & 3.86 & 4232 \\
\hline & 30000 & 25.1 & 0.91 & 0.70 & 0.45 & 4.01 & 4134 \\
\hline
\end{tabular}

${ }^{1}$ AOAC Method 988.05, 920.87, 991.20; Kjeldahl.

${ }^{2}$ AOAC Method 968.08, 927.02, 935.13, 985.35; Atomic Absorption Spectrophotometry.

${ }^{3}$ AOAC method 965.17; Spectrophotometry.

${ }^{4}$ Non-phytate phosphorus $=$ total phosphorus $($ AOAC Method 965.17/985.01 mod) $-[0.282 \mathrm{X}$ phytic acid $($ AOAC method 986.11) $\mathrm{x}$ 100.

${ }^{5}$ Nitrogen $=$ Crude Protein $($ AOAC Method 988.05, 920.87, 991.20; Kjeldahl $) / 6.25$.

${ }^{6}$ NPSOP3000, Validation of Quantitative Chemical Tests. No. 463M: Operating Manual for the 6300 Isoperibol Calorimeter.

${ }^{7}$ The authors are still waiting on these results from the lab. AOAC method 2000.12; Phytase.

$* 0.2 \%$ titanium dioxide was top dressed in diets for mineral digestibility determination. 
Table 3. Performance data obtained from 7 and 14-day old broilers.

\begin{tabular}{|c|c|c|c|c|c|c|c|c|c|c|c|c|}
\hline \multirow{2}{*}{$\begin{array}{c}\text { ME Level } \\
(\mathrm{kcal} / \mathrm{kg})\end{array}$} & \multirow{2}{*}{$\begin{array}{l}\text { Phytase Dose } \\
\text { (FTU/kg) }\end{array}$} & \multirow{2}{*}{$\begin{array}{l}\text { Starting Pen } \\
\text { Weight }^{1}(\mathrm{~kg})\end{array}$} & \multicolumn{5}{|c|}{ D7 } & \multicolumn{5}{|c|}{ D14 } \\
\hline & & & $\begin{array}{l}\text { Ending Bird } \\
\text { Weight }(\mathrm{kg})\end{array}$ & $\begin{array}{l}\text { Pen FI }^{2} \\
(\mathrm{~kg})\end{array}$ & $\mathrm{FCR}^{3}$ & $\begin{array}{c}\text { Bird } \\
\text { LWG }^{4}(\mathrm{~kg})\end{array}$ & $\begin{array}{c}\text { Mortality }^{5} \\
(\%)\end{array}$ & $\begin{array}{l}\text { Ending Bird } \\
\text { Weight }(\mathrm{kg})\end{array}$ & $\begin{array}{c}\text { Pen FI } \\
(\mathrm{kg})\end{array}$ & FCR & $\begin{array}{c}\text { Bird } \\
\text { LWG }(\mathrm{kg})\end{array}$ & $\begin{array}{c}\text { Mortality } \\
(\%)\end{array}$ \\
\hline \multirow{5}{*}{$\begin{array}{c}2701 \\
(\mathrm{NC} 1)\end{array}$} & 0 & 0.432 & 0.172 & $1.51^{\mathrm{abcd}}$ & $1.18^{\mathrm{ab}}$ & 0.129 & 0.00 & $0.437^{\mathrm{e}}$ & $5.36^{\text {abcd }}$ & $1.39^{\mathrm{a}}$ & $0.393^{\mathrm{e}}$ & $2.22^{\mathrm{ab}}$ \\
\hline & 1500 & 0.430 & 0.170 & $1.49^{\text {abcde }}$ & $1.18^{\mathrm{a}}$ & 0.127 & 1.11 & $0.441^{\mathrm{de}}$ & $5.33^{\text {abcde }}$ & $1.35^{\mathrm{bc}}$ & $0.398^{\mathrm{de}}$ & $1.11^{\mathrm{b}}$ \\
\hline & 4500 & 0.433 & 0.171 & $1.50^{\mathrm{abcd}}$ & $1.18^{\mathrm{a}}$ & 0.128 & 0.00 & $0.438^{\mathrm{de}}$ & $5.41^{\mathrm{abc}}$ & $1.37^{\mathrm{ab}}$ & $0.394^{\mathrm{de}}$ & $0.00^{\mathrm{b}}$ \\
\hline & 13500 & 0.432 & 0.176 & $1.54^{\mathrm{ab}}$ & $1.16^{\mathrm{abc}}$ & 0.133 & 0.00 & $0.454^{\text {abcde }}$ & $5.47^{\mathrm{ab}}$ & $1.33^{\mathrm{cd}}$ & $0.411^{\text {abcde }}$ & $0.00^{\mathrm{b}}$ \\
\hline & 30000 & 0.431 & 0.175 & $1.51^{\mathrm{abcd}}$ & $1.15^{\mathrm{bcd}}$ & 0.132 & 0.00 & $0.451^{\text {bcde }}$ & $5.47^{\mathrm{ab}}$ & $1.34^{\mathrm{c}}$ & $0.408^{\text {bcde }}$ & $0.00^{\mathrm{b}}$ \\
\hline \multirow{5}{*}{$\begin{array}{c}2868 \\
(\mathrm{NC} 2)\end{array}$} & 0 & 0.432 & 0.168 & $1.44^{\mathrm{def}}$ & $1.16^{\mathrm{abc}}$ & 0.124 & 1.11 & $0.435^{\mathrm{e}}$ & $5.11^{\mathrm{efg}}$ & $1.33^{\mathrm{cd}}$ & $0.392^{\mathrm{e}}$ & $4.44^{\mathrm{a}}$ \\
\hline & 1500 & 0.432 & 0.173 & $1.49^{\mathrm{abcde}}$ & $1.15^{\mathrm{cd}}$ & 0.130 & 0.00 & $0.457^{\mathrm{abcd}}$ & $5.33^{\text {abcde }}$ & $1.29^{\mathrm{ef}}$ & $0.414^{\text {abcd }}$ & $0.00^{\mathrm{b}}$ \\
\hline & 4500 & 0.432 & 0.179 & $1.53^{\mathrm{abc}}$ & $1.13^{\mathrm{de}}$ & 0.136 & 0.00 & $0.464^{\mathrm{abc}}$ & $5.44^{\mathrm{abc}}$ & $1.30^{\mathrm{e}}$ & $0.421^{\mathrm{abc}}$ & $1.11^{\mathrm{b}}$ \\
\hline & 13500 & 0.433 & 0.171 & $1.46^{\text {bcdef }}$ & $1.15^{\mathrm{bcd}}$ & 0.128 & 0.00 & $0.454^{\text {abcde }}$ & $5.28^{\text {bcde }}$ & $1.29^{\mathrm{efg}}$ & $0.411^{\text {abcde }}$ & $0.00^{\mathrm{b}}$ \\
\hline & 30000 & 0.432 & 0.180 & $1.55^{\mathrm{a}}$ & $1.14^{\text {cde }}$ & 0.136 & 0.00 & $0.472^{\mathrm{a}}$ & $5.56^{\mathrm{a}}$ & $1.31^{\mathrm{de}}$ & $0.428^{\mathrm{a}}$ & $1.11^{\mathrm{b}}$ \\
\hline \multirow{5}{*}{$\begin{array}{c}3000 \\
(\mathrm{NC} 3)\end{array}$} & 0 & 0.433 & 0.169 & $1.42^{\mathrm{ef}}$ & $1.13^{\mathrm{de}}$ & 0.126 & 0.00 & $0.447^{\text {cde }}$ & $5.04^{\mathrm{fg}}$ & $1.26^{\mathrm{gh}}$ & $0.404^{\text {cde }}$ & $1.11^{\mathrm{b}}$ \\
\hline & 1500 & 0.432 & 0.172 & $1.46^{\text {cdef }}$ & $1.14^{\text {cde }}$ & 0.129 & 0.00 & $0.452^{\text {bcde }}$ & $5.14^{\operatorname{defg}}$ & $1.26^{\mathrm{fgh}}$ & $0.408^{\text {abcde }}$ & $0.00^{\mathrm{b}}$ \\
\hline & 4500 & 0.432 & 0.168 & $1.40^{\mathrm{f}}$ & $1.12^{\mathrm{def}}$ & 0.125 & 0.00 & $0.455^{\text {abcde }}$ & $4.98^{\mathrm{g}}$ & $1.23^{\mathrm{i}}$ & $0.411^{\text {abcde }}$ & $2.22^{\mathrm{ab}}$ \\
\hline & 13500 & 0.432 & 0.175 & $1.47^{\text {bcdef }}$ & $1.12^{\mathrm{ef}}$ & 0.132 & 0.00 & $0.470^{\mathrm{ab}}$ & $5.27^{\text {bcdef }}$ & $1.24^{\mathrm{hi}}$ & $0.427^{\mathrm{ab}}$ & $0.00^{\mathrm{b}}$ \\
\hline & 30000 & 0.431 & 0.175 & $1.46^{\text {def }}$ & $1.10^{\mathrm{f}}$ & 0.132 & 0.00 & $0.468^{\mathrm{ab}}$ & $5.21^{\text {cdefg }}$ & $1.23^{\mathrm{i}}$ & $0.425^{\mathrm{ab}}$ & $0.00^{\mathrm{b}}$ \\
\hline \multicolumn{2}{|c|}{ Treatment $P$-value } & 0.7443 & 0.0809 & 0.0031 & $<0.0001$ & 0.0793 & 0.4584 & 0.0011 & $<0.0001$ & $<0.0001$ & 0.0011 & 0.0152 \\
\hline \multicolumn{2}{|c|}{ Fisher's LSD } & --- & --- & 0.0757 & 0.0273 & --- & --- & 0.0200 & 0.2374 & 0.0277 & 0.0200 & 2.4473 \\
\hline \multicolumn{2}{|c|}{ Treatment SEM } & 0.0009 & 0.0029 & 0.0270 & 0.0097 & 0.0029 & 0.3910 & 0.0071 & 0.0847 & 0.0099 & 0.0071 & 0.8734 \\
\hline \multicolumn{13}{|c|}{ Marginal Means } \\
\hline 2701 & --- & 0.431 & 0.173 & $1.51^{\mathrm{a}}$ & $1.17^{\mathrm{a}}$ & 0.130 & 0.222 & $0.444^{\mathrm{b}}$ & $5.41^{\mathrm{a}}$ & $1.36^{\mathrm{a}}$ & $0.401^{\mathrm{b}}$ & 0.67 \\
\hline 2868 & --- & 0.432 & 0.174 & $1.49^{\mathrm{a}}$ & $1.14^{\mathrm{b}}$ & 0.131 & 0.222 & $0.456^{\mathrm{a}}$ & $5.34^{\mathrm{a}}$ & $1.30^{\mathrm{b}}$ & $0.413^{\mathrm{a}}$ & 1.33 \\
\hline 3000 & --- & 0.432 & 0.172 & $1.44^{\mathrm{b}}$ & $1.12^{\mathrm{c}}$ & 0.129 & 0.000 & $0.458^{\mathrm{a}}$ & $5.13^{b}$ & $1.24^{\mathrm{c}}$ & $0.415^{\mathrm{a}}$ & 0.67 \\
\hline \multicolumn{2}{|c|}{ SEM } & 0.0004 & 0.0013 & 0.0121 & 0.0044 & 0.0013 & 0.1748 & 0.0032 & 0.0379 & 0.0044 & 0.0032 & 0.3906 \\
\hline & & & & & & & & & & & & \\
\hline--- & 0 & 0.432 & $0.170^{\mathrm{b}}$ & 1.46 & $1.16^{\mathrm{a}}$ & $0.126^{\mathrm{b}}$ & 0.370 & $0.440^{\mathrm{c}}$ & $5.17^{\mathrm{c}}$ & $1.33^{\mathrm{a}}$ & $0.396^{\mathrm{c}}$ & $2.59^{\mathrm{a}}$ \\
\hline--- & 1500 & 0.431 & $0.172^{\mathrm{b}}$ & 1.48 & $1.16^{\mathrm{a}}$ & $0.129^{\mathrm{b}}$ & 0.370 & $0.450^{\mathrm{bc}}$ & $5.27^{\mathrm{bc}}$ & $1.30^{\mathrm{b}}$ & $0.407^{\mathrm{bc}}$ & $0.37^{\mathrm{b}}$ \\
\hline--- & 4500 & 0.432 & $0.173^{\mathrm{ab}}$ & 1.48 & $1.14^{\mathrm{a}}$ & $0.129^{\mathrm{ab}}$ & 0.000 & $0.452^{\mathrm{b}}$ & $5.28^{\mathrm{abc}}$ & $1.30^{\mathrm{b}}$ & $0.409^{\mathrm{b}}$ & $1.11^{\mathrm{b}}$ \\
\hline--- & 13500 & 0.432 & $0.174^{\mathrm{ab}}$ & 1.49 & $1.14^{\mathrm{ab}}$ & $0.131^{\mathrm{ab}}$ & 0.000 & $0.459^{\mathrm{ab}}$ & $5.34^{\mathrm{ab}}$ & $1.28^{\mathrm{c}}$ & $0.416^{\mathrm{ab}}$ & $0.00^{\mathrm{b}}$ \\
\hline--- & 30000 & 0.432 & $0.177^{\mathrm{a}}$ & 1.51 & $1.13^{\mathrm{b}}$ & $0.134^{\mathrm{a}}$ & 0.000 & $0.464^{\mathrm{a}}$ & $5.41^{\mathrm{a}}$ & $1.29^{\mathrm{bc}}$ & $0.421^{\mathrm{a}}$ & $0.37^{\mathrm{b}}$ \\
\hline \multicolumn{2}{|r|}{ SEM } & 0.0005 & 0.0017 & 0.0156 & 0.0056 & 0.0017 & 0.2257 & 0.0041 & 0.0489 & 0.0057 & 0.0041 & 0.5042 \\
\hline \multicolumn{13}{|c|}{ Main Effects and Interactions } \\
\hline \multicolumn{2}{|c|}{ ME Level } & 0.4355 & 0.4756 & 0.0002 & $<0.0001$ & 0.4899 & 0.5851 & 0.0033 & $<0.0001$ & $<0.0001$ & 0.0034 & 0.3818 \\
\hline \multicolumn{2}{|c|}{ Phytase Dose } & 0.7422 & 0.0468 & 0.3016 & 0.0040 & 0.0447 & 0.5228 & 0.0008 & 0.0106 & $<0.0001$ & 0.0008 & 0.0033 \\
\hline \multicolumn{2}{|c|}{ ME Level x Phytase Dose } & 0.5902 & 0.1946 & 0.1385 & 0.5371 & 0.1932 & 0.2987 & 0.4871 & 0.1460 & 0.0508 & 0.4829 & 0.2148 \\
\hline
\end{tabular}

${ }^{1}$ Starting pen weights were based on 10 birds/pen. 
${ }^{2} \mathrm{FI}=$ Feed Intake.

${ }^{3} \mathrm{FCR}=$ Feed Conversion Ratio (Feed:Gain) was calculated using mortality weight.

${ }^{4} \mathrm{LWG}=$ Live Weight Gain.

${ }^{5}$ Mortality percentage is based on 10 birds/pen, so if 2 birds died the mortality percentage would be $20 \%$ for that study unit/pen.

${ }^{\mathrm{a}-\mathrm{i}}$ Means within a column not sharing a common superscript differ significantly $(\mathrm{P}<0.05)$. 
Table 4. Performance data and AMEn obtained from 21-day old broilers.

\begin{tabular}{|c|c|c|c|c|c|c|c|}
\hline ME Level (kcal/kg) & Phytase Dose (FTU/kg) & Ending Bird Weight (kg) & $\mathrm{Pen} \mathrm{FI}^{1}(\mathrm{~kg})$ & $\mathrm{FCR}^{2}$ & Bird LWG ${ }^{3}(\mathrm{~kg})$ & Mortality $^{4}(\%)$ & AMEn (kcal/kg) \\
\hline \multirow{5}{*}{$\begin{array}{c}2701 \\
(\mathrm{NC} 1)\end{array}$} & 0 & $0.857^{\mathrm{g}}$ & $12.23^{\mathrm{ab}}$ & $1.53^{\mathrm{a}}$ & $0.814^{\mathrm{g}}$ & 2.22 & $2952^{\mathrm{d}}$ \\
\hline & 1500 & $0.879^{\text {efg }}$ & $12.15^{\mathrm{abc}}$ & $1.47^{\mathrm{bc}}$ & $0.836^{\mathrm{efg}}$ & 1.11 & $3001^{\mathrm{d}}$ \\
\hline & 4500 & $0.868^{\mathrm{fg}}$ & $12.25^{\mathrm{ab}}$ & $1.50^{\mathrm{ab}}$ & $0.825^{\mathrm{fg}}$ & 1.11 & \\
\hline & 13500 & $0.898^{\text {def }}$ & $12.28^{\mathrm{ab}}$ & $1.46^{\text {cde }}$ & $0.855^{\mathrm{def}}$ & 2.22 & $2773^{\mathrm{e}}$ \\
\hline & 30000 & $0.888^{\text {efg }}$ & $12.29^{\mathrm{ab}}$ & $1.46^{\mathrm{cd}}$ & $0.845^{\text {efg }}$ & 1.11 & $2949^{d}$ \\
\hline \multirow{5}{*}{$\begin{array}{l}2868 \\
(\mathrm{NC} 2)\end{array}$} & 0 & $0.881^{\text {efg }}$ & $11.66^{\mathrm{de}}$ & $1.45^{\text {cdef }}$ & $0.838^{\mathrm{efg}}$ & 5.56 & $3457^{\mathrm{a}}$ \\
\hline & 1500 & $0.924^{\text {bcd }}$ & $12.23^{\mathrm{abc}}$ & $1.39^{\mathrm{gh}}$ & $0.880^{\text {bcd }}$ & 0.00 & $3176^{\mathrm{c}}$ \\
\hline & 4500 & $0.924^{\text {bcd }}$ & $12.31^{\mathrm{ab}}$ & $1.42^{\mathrm{fg}}$ & $0.881^{\text {bcd }}$ & 2.22 & \\
\hline & 13500 & $0.903^{\mathrm{de}}$ & $12.23^{\mathrm{ab}}$ & $1.42^{\operatorname{defg}}$ & $0.860^{\mathrm{de}}$ & 0.00 & $3034^{\mathrm{d}}$ \\
\hline & 30000 & $0.938^{\mathrm{abc}}$ & $12.56^{\mathrm{a}}$ & $1.42^{\mathrm{efg}}$ & $0.895^{\mathrm{abc}}$ & 1.11 & \\
\hline \multirow{5}{*}{$\begin{array}{c}3000 \\
(\mathrm{NC} 3)\end{array}$} & 0 & $0.911^{\text {cde }}$ & $11.58^{\mathrm{e}}$ & $1.36^{\mathrm{hi}}$ & $0.868^{\text {cde }}$ & 2.22 & $3324^{\mathrm{b}}$ \\
\hline & 1500 & $0.930^{\mathrm{abcd}}$ & $11.76^{\mathrm{cde}}$ & $1.34^{\mathrm{ij}}$ & $0.887^{\mathrm{abcd}}$ & 1.11 & \\
\hline & 4500 & $0.945^{\mathrm{abc}}$ & $11.49^{\mathrm{e}}$ & $1.31^{\mathrm{j}}$ & $0.902^{\mathrm{abc}}$ & 3.33 & \\
\hline & 13500 & $0.958^{\mathrm{a}}$ & $12.11^{\mathrm{abcd}}$ & $1.34^{\mathrm{ij}}$ & $0.915^{\mathrm{a}}$ & 2.22 & \\
\hline & 30000 & $0.952^{\mathrm{ab}}$ & $11.85^{\text {bcde }}$ & $1.32^{\mathrm{j}}$ & $0.909^{\mathrm{ab}}$ & 2.22 & \\
\hline \multicolumn{2}{|c|}{ Treatment $P$-value } & $<0.0001$ & $<0.0001$ & $<0.0001$ & $<0.0001$ & 0.6081 & $<0.0001$ \\
\hline \multicolumn{2}{|c|}{ Fisher's LSD } & 0.0340 & 0.4674 & 0.0396 & 0.0340 & --- & 108.99 \\
\hline \multicolumn{2}{|c|}{ Treatment SEM } & 0.0121 & 0.1668 & 0.0141 & 0.0122 & 1.4828 & 38.4699 \\
\hline 2701 & --- & $0.878^{\mathrm{c}}$ & $12.24^{\mathrm{a}}$ & $1.48^{\mathrm{a}}$ & $0.835^{\mathrm{c}}$ & 1.56 & \\
\hline 2868 & --- & $0.914^{\mathrm{b}}$ & $12.20^{\mathrm{a}}$ & $1.42^{\mathrm{b}}$ & $0.871^{\mathrm{b}}$ & 1.78 & \\
\hline 3000 & --- & $0.939^{\mathrm{a}}$ & $11.76^{\mathrm{b}}$ & $1.33^{\mathrm{c}}$ & $0.896^{\mathrm{a}}$ & 2.22 & \\
\hline \multicolumn{2}{|c|}{ SEM } & 0.0054 & 0.0746 & 0.0063 & 0.0054 & 0.6631 & \\
\hline--- & 0 & $0.883^{\mathrm{b}}$ & $11.82^{\mathrm{b}}$ & $1.45^{\mathrm{a}}$ & $0.840^{\mathrm{b}}$ & 3.33 & \\
\hline--- & 1500 & $0.911^{\mathrm{a}}$ & $12.04^{\mathrm{ab}}$ & $1.40^{\mathrm{b}}$ & $0.868^{\mathrm{a}}$ & 0.741 & \\
\hline--- & 4500 & $0.912^{\mathrm{a}}$ & $12.01^{\mathrm{ab}}$ & $1.41^{\mathrm{b}}$ & $0.869^{\mathrm{a}}$ & 2.22 & \\
\hline--- & 13500 & $0.920^{\mathrm{a}}$ & $12.21^{\mathrm{a}}$ & $1.41^{\mathrm{b}}$ & $0.877^{\mathrm{a}}$ & 1.48 & \\
\hline--- & 30000 & $0.926^{\mathrm{a}}$ & $12.23^{\mathrm{a}}$ & $1.40^{\mathrm{b}}$ & $0.883^{\mathrm{a}}$ & 1.48 & \\
\hline \multicolumn{2}{|c|}{ SEM } & 0.0070 & 0.0963 & 0.0082 & 0.0070 & 0.8561 & \\
\hline \multicolumn{8}{|c|}{ Main Effects and Interactions } \\
\hline \multicolumn{2}{|c|}{ ME Level } & $<0.0001$ & $<0.0001$ & $<0.0001$ & $<0.0001$ & 0.7700 & \\
\hline \multirow{2}{*}{\multicolumn{2}{|c|}{$\begin{array}{c}\text { Phytase Dose } \\
\text { ME Level x Phytase Dose }\end{array}$}} & 0.0005 & 0.0248 & 0.0001 & 0.0005 & 0.2706 & \\
\hline & & 0.4246 & 0.1408 & 0.0996 & 0.4208 & 0.6240 & \\
\hline
\end{tabular}

${ }^{1} \mathrm{FI}=$ Feed Intake. 
${ }^{2}$ FCR $=$ Feed Conversion Ratio (Feed:Gain) was calculated using mortality weight.

${ }^{3} \mathrm{LWG}=$ Live Weight Gain.

${ }^{4}$ Mortality percentage is based on 10 birds/pen, so if 2 birds died the mortality percentage would be $20 \%$ for that study unit/pen.

${ }^{\mathrm{a}-\mathrm{i}}$ Means within a column not sharing a common superscript differ significantly $(\mathrm{P}<0.05)$. 


\section{Angela E. Lamp}

·angelalamp951@gmail.com·

\section{EDUCATION}

Doctor of Philosophy - Ongoing, PhD Candidate; West Virginia University

Major: $\quad$ Animal and Food Science

Dissertation: Evaluating Inorganic Feed Phosphate Type and Further Potential

Phytase Supplementation using a Commercial Broiler Model

Master of Science - $\quad$ 2013; West Virginia University

Major: Nutritional and Food Science

Thesis: $\quad$ Improving Opportunities for Small Flock Poultry and Efficiency of Commercial Poultry

Bachelor of Science - 2012; West Virginia University

Major: $\quad$ Animal and Nutritional Sciences

\section{EDUCATION HONORS/AWARDS}

Awards and Honors:

- Graduate Student Research Paper Certificate of Achievement, Feed manufacture technique affects heat transfer to feed that may influence nutritional value. 2013 International Southern Poultry Science Forum. Atlanta, GA.

- Graduate Student Research Paper Certificate of Excellence, The effect of pelleting and glucanase supplementation in barley based diets on feed manufacture, broiler performance, and gut viscosity. 2013 Poultry Science Association Meeting. San Diego, CA.

- Graduated from Weir High School in 2008

- Member of National Honor Society, Weir HS Chapter (2006-2008)

- Salutatorian

- All Conference Academic Award

- Who's Who Among High School Students

- Student Council Treasurer

- USAA National English Award

\section{Scholarships Received:}

- Riverside Medical Scholarship (2008-2009)

- Aggarwal Family Scholarship (2008-2009)

- Kristen Andrews Scholarship (2008-2009)

- Stark Foundation Scholarship (2008-2009) 
- West Virginia Promise Scholarship (2008-2012)

- A. Michael Perry Scholarship (2008-2010)

\section{Author Publications:}

\section{Peer-Reviewed Manuscripts}

A. E. Lamp, A. M. Evans, and J. S. Moritz. 2015. The effects of pelleting and glucanase supplementation in hulled barley based diets on feed manufacture, broiler performance, and digesta viscosity. J. Appl. Poult. Res. 00:1-9.

A. E. Lamp, A. Mereu, I. Ruiz-Ascacibar, and J. S. Moritz. 2019. Inorganic feed phosphate type determines mineral digestibility, broiler performance and bone mineralization. J. Appl. Poult. Res. Accepted.

A. E. Lamp, N. E. Ward, J. W. Wilson, and J. S. Moritz. 2019. In vitro phytase activity post steam conditioning and pelleting may not consistently correlate with in vivo measurements among commercial phytases. J. Appl. Poult. Res. In Press.

T. P. Boltz, N. Ward, V. E. Ayres, A. E. Lamp, and J. S. Moritz. 2020. The Effect of Varying Steam Conditioning Temperature and Time on Pellet Manufacture Variables, True Amino Acid Digestibility, and Feed Enzyme Recovery. J. Appl. Poult. Res. In Press.

\section{Peer-Reviewed Abstracts}

A. E. Lamp, N. Ward, J. Wilson, and J. S. Moritz. In vitro phytase activity post steam conditioning and pelleting may not consistently correlate with broiler performance, tibia mineralization, and blood myo-inositol concentration among commercial phytases. July 2019. Poult. Sci. Vol. 98 (Suppl. 1): 94.

T. Boltz, N. Ward, V. Ayres, A. E. Lamp, and J. S. Moritz. The effect of varying steam conditioning temperature and time on pellet manufacture variables, digestible amino acid concentration, and feed enzyme recovery. July 2019. Poult. Sci. Vol. 98 (Suppl. 1): 171.

V. Ayres, T. Boltz, A. E. Lamp, and J. Moritz. Exogenous enzyme supplementation can overcome amino acid deficient diets. July 2019. Poult. Sci. Vol. 98 (Suppl. 1): 503P.

K. Harding, A. E. Lamp, T. Boltz, V. Ayres, and J. Moritz. The effect of pelleting diets composed of large particle corn using standard conditioning and more thermally aggressive conditioning utilizing a hygienizer. July 2019. Poult. Sci. Vol. 98 (Suppl. 1): 521P.

A. E. Lamp, A. Mereu, and J. S. Moritz. Diets that differ in inorganic feed phosphates will affect early broiler performance and tibia mineralization. July 2018. Poult. Sci. Vol. 97 (Suppl. 1): 150.

A. E. Lamp and J. S Moritz. The effect of pelleting and glucanase supplementation in barley based diets on feed manufacture, broiler performance, and gut viscosity. July 2013. Poult. Sci. Vol. 92 (Suppl. 1): 104.

A. E. Lamp, A. M. Evans, and J. S Moritz. Feed manufacture technique affects heat transfer to feed that may influence nutritional value. 2013 International Poultry Science Forum. January 2013. Pg. 256: P194.

J. W. Boney, A. E. Lamp, and J. S Moritz. The effects of wheat supplementation to corn and soybean meal based diets on the manufacture of pellets and subsequent turkey performance. July 2013. Poult. Sci. Vol. 92 (Suppl. 1): 43. 
A. E. Lamp, M. E. Lemons, K. G. S. Wamsley, and J. S. Moritz. The effect of pasture access, breed, and diet on laying hen health, performance, and EPA and DHA content of eggs. July 2012. Poult. Sci. Vol. 91 (Suppl. 1): 133.

M. E. Lemons, K. G. S. Wamsley, A. E. Lamp, A. M. Evans, K. J. Shipe, and J. S. Moritz. Lignosulfonate pellet binder and fat increase broiler feed retention time. July 2012. Poult. Sci. Vol. 91 (Suppl. 1): 130.

A. E. Lamp, K. G. S. Lilly, B. N. Swiger, K. Matak, and J. S. Moritz. The effect of marine and flaxseed oil inclusion in diets for pastured laying flocks on EPA, DHA, and consumer acceptability of eggs. $18^{\text {th }}$ European Symposium on Poultry Nutrition. Poster in CesmeIzmir, Turkey. November 2011.

A. E. Lamp, K. G. S. Lilly, B. N. Swiger, and J. S. Moritz. The effect of marine and flaxseed oil inclusion in diets for pastured laying flocks on EPA, DHA, and consumer acceptability of eggs. July 2011. Poult. Sci. Vol. 90 (Suppl. 1): 338.

\section{RESEARCH EXPERIENCE}

\section{National Meeting Oral Presentations}

- 2019 Poultry Science Association (Montréal, Québec, Canada)

- In vitro phytase activity post steam conditioning and pelleting may not consistently correlate with broiler performance, tibia mineralization, and blood myo-inositol concentration among commercial phytases.

- 2018 Poultry Science Association (San Antonio, TX)

- Diets that differ in inorganic feed phosphates will affect early broiler performance and tibia mineralization.

- 2013 Poultry Science Association (San Diego, CA)

- The effect of pelleting and glucanase supplementation in barley based diets on feed manufacture, broiler performance, and gut viscosity.

- 2012 Poultry Science Association (Athens, GA)

- The effect of pasture access, breed, and diet on laying hen health, performance, and EPA and DHA content of eggs.

- 2011 Poultry Science Association (St. Louis, MO) (Undergraduate Student)

- The effect of marine and flaxseed oil inclusion in diets for pastured laying flocks on EPA, DHA, and consumer acceptability of eggs.

\section{National Meeting Poster Presentations}

- 2013 International Poultry Science Forum (Atlanta, GA)

- Feed manufacture technique affects heat transfer to feed that may influence nutritional value.

- $201118^{\text {th }}$ European Symposium on Poultry Nutrition (Cesme- Izmir, Turkey) (Undergraduate Student)

- The effect of marine and flaxseed oil inclusion in diets for pastured laying flocks on EPA, DHA, and consumer acceptability of eggs. 


\section{Graduate Research Assistant (PhD): 2017 - 2019}

- Led a contract study with Yara International examining the effects of various inorganic feed phosphates on broiler performance, tibia mineralization, and mineral digestibility.

- Led contract study with DSM Nutritional Products Inc. examining broilers fed diets containing different phytase enzymes conditioned at different temperatures and correlated phytase activity post pelleting with broiler performance, tibia mineralization, and blood plasma myo-inositol concentration.

- Led two contract studies with Huvepharma Inc. evaluating the thermostability of phytase and xylanase products at different conditioning temperatures.

- Mentor for Student Undergraduate Research Experience (SURE) examining growth performance, mortality, and carcass traits of organic meat-type chickens fed diets that differed in synthetic methionine inclusion.

- Assisted graduate and undergraduate students with contract studies with Agrivida Inc., Huvepharma Inc., DSM Nutritional Products Inc., and United Animal Health.

\section{Graduate Teaching Assistant (PhD): 2017 - 2019}

- Teaching Assistant for Poultry Production and Poultry Production Lab (ANPR 367 \& ANPR 369)

- Organized field trips

- Accompanied students to the International Poultry Science Forum in Atlanta, GA

- Mentored students as they raised broilers to 42 days

- Teaching Assistant for Poultry Evaluation Course (ANPR 338)

- Setup mock judging rings for class each day

- Accompanied students to the Collegiate Poultry Judging Competition held in Baton Rouge, LA

- Guest Lectures

- Minerals and Ether Extract lecture for Advanced Applied Non-Ruminant Nutrition ANNU 362

- Feed Manufacture lecture for Poultry Production Class ANPR 367

- Poultry Evaluation and Anatomy lecture for Principals of Animal Science (A\&VS 251)

\section{Graduate Research Assistant (MS): 2012 - 2013}

- Led four contract studies with Verenium

- Led two studies that evaluated the efficacy of exogenous xylanase enzymes using a broiler model by examining broiler performance, gut viscosity, and AME.

- Led two studies that evaluated the efficacy of experimental glucanase enzymes in mash and pelleted diets through broiler performance and gut viscosity.

- Assisted with three contract studies with Virginia Poultry Grower's Co-op examining if poult and tom performance are affected by pellet quality and nutrient availability associated with the inclusion of wheat to the diet formulation.

- Assisted with contract studies with Verenium and Borregaard Lignotech

Graduate Teaching Assistant (MS): 2012 - 2013

- Teaching Assistant for Poultry Evaluation Course (ANPR 339)

- Teaching Assistant for Companion Animal Science (A\&VS 275) 
- Guest Lecturer on Poultry Evaluation for Principles of Animal Science Class (A\&VS 251)

Undergraduate Research Assistant : 2011 - 2012

- Led eight contract studies with Verenium

- Led one study that evaluated the efficacy of an experimental microbial expressed phytase and various energy releasing enzymes using a broiler model by examining broiler performance and tibia ash.

- Led two studies that evaluated the efficacy of exogenous xylanase enzymes using a broiler model by examining broiler performance, gut viscosity, and AME.

- Led five studies that evaluated the efficacy of exogenous xylanase enzymes using a rooster model by determined the nitrogen true metabolizable energy (TMEn).

- Co-led an in-house experiment to determine the effect of pasture access, breed, and diet on laying hen health, performance, and EPA and DHA content of eggs

- Assisted with Contract Studies with JBS United, Phytex, Verenium, Poet Nutrition, Borregaard Lignotech, and Adisseo Inc.

\section{Undergraduate Teaching Assistant: 2012}

- Teaching Assistant for Poultry Evaluation Course (ANPR 338)

- Guest Lecturer on Poultry Evaluation for Principles of Animal Science Class (A\&VS 251)

\section{State Extension Activities}

- Assisted with Poultry Workshop at WVU Organic Field Day (8/4/2011)

- Assisted with WV poultry week activities (2011), (7/26-7/27/2012), (7/23-7/29/2017), and $(7 / 17-7 / 18 / 2018)$

- Assisted with activities and displays (birds and poster) for Monongalia County (2011)

- Assisted with Extension talks on backyard poultry production: Doddridge County (2/20/2012), Roane County (2/21/2012), Wood County (2/23/2012), Monongalia County (8/8/2012), Gilmer County (10/18/2012), Hico, WV (2/5/2018), and Princeton, WV $(2 / 7 / 2018)$

- Preston County Kid's Safety Day (6/9/2012) and (6/8/2013)

- Guest Lecturer at Organic Poultry Field Day (8/9/2012)

- Assisted with running of the Poultry Building at the WV State Fair (8/15-8/16/2012)

- Assisted with Marion County Hands-on Ag Day (9/20/2012)

- Assisted with Family Day at the WVU Animal Science Farm (10/6/2012)

- Assisted with Doddridge County, WV Poultry Processing Workshop (8/2013)

- Poultry Judge for County Fairs: Berkeley County Youth Fair, WV (8/7/2012), Monongalia County, WV (8/9/2012, 8/1/2013, 8/4/2017, 8/2/2018, 8/13/2019), and Garrett County, MD (7/29/2018, 7/28/2019)

- Assisted with Poultry Career Development Events (9/26/2012), (6/19/2013), (9/14/2017), $(9 / 13 / 2018)$, and $(9 / 11 / 2019)$

- Egg Judge for FFA Ham, Bacon, and Egg Sale: Monongalia County, WV (4/12/2019)

- Assisted with Extension talks and workshops on backyard poultry production: Pineville, WV $(12 / 2017-10 / 2019)$ 


\section{EXPERIENCE}

Michael Foods - Wakefield, NE

Poultry Nutritionist, January 2020 - ongoing

- Formulating optimal feed rations for over 100 laying hen/pullet flocks each week

- Monitoring feed ingredients received at mills for nutrient levels and appropriate quality evaluations

- Working with corporate purchasing to evaluate best decisions for major feed ingredient suppliers based upon cost and available nutrient content

- Interacting with sales team members (sales/technical) with feed additive companies to consider evaluation feed products for testing or maintaining relationship/updating information with current suppliers

- Working as part of a nutrition team with other nutritionist and feed ingredient procurement to evaluate current and future needs and plans for the nutrition program

- Evaluating the production data and shell quality reports to monitor changes needed to optimize the nutrition program for each individual flock

- Managing 500-bird research house for more intense studies on nutritional evaluations for laying hens

West Virginia University - Morgantown, WV

Poultry Farm Manager, July 2017 - May 2020

- Daily care of around 500 live poultry at the West Virginia University Research Farm

- Mentoring and training graduate and undergraduate students on proper care and handling of poultry

- General building maintenance and upkeep

Riverbanks Zoo and Garden - Columbia, SC

Bird Keeper, March 2016 - June 2017

- Husbandry Experience

- Daily care of exhibits housing approximately 300 individual birds

- Cleaning, handling, medicating, feeding, enrichment, bird counts, observing behavior, exhibit maintenance

- Training Experience

- Mentoring and training departmental interns

- Presentation Experience

- Assisting with private educational tours

- Regular interaction with guests and answering questions

Oglebay Zoo - Wheeling, WV

Zoo Animal Care Intern, September 2015 - March 2016

- Husbandry Experience

- Daily care of exhibits housing approximately 50 different species of animals

- Cleaning, preparing diets, handling, medicating, feeding, enrichment, and observing behavior 
National Aviary - Pittsburgh, PA

Assistant Aviculturist, October 2014 - March 2016

Intern, May 2014 - October 2014

- Husbandry Experience

- Daily care of exhibits housing approximately 500 individual birds representing over 150 species

- Cleaning, preparing diets, handling, medicating, feeding, enrichment, bird counts, observing behavior, exhibit construction and remodeling

- Training Experience

- Operant conditioning using positive reinforcement

- Completed Training 101 and 201 seminars provided by National Aviary

- Mentoring \& Training departmental Interns/Volunteers

- Presentation Experience

- Leading daily public feedings with audience participation

- Regular interaction with aviary guests and answering questions

West Virginia University - Morgantown, WV

Undergraduate and Graduate Research and Teaching Assistant, June 2011-December 2013

Community Care Animal Hospital - Follansbee, WV

Animal Care Attendant, May 2009 - August 2009

- Animal Care Experience

- Restraining individuals during medical procedures

- Assisting with $\mathrm{x}$-rays

- Performing fecal floats

- Feeding

Hancock County Animal Shelter - New Cumberland, WV

Animal Care Attendant, May 2008 - August 2008

- Animal Care Experience

- Cleaning, feeding, medicating

- Fostered relationships between adopters and animals

\section{SKILLS}

- Experience formulating diets using Feed Ration Balancer

- Poultry handling, evaluation, and husbandry

- Feed Manufacture

- Diet Formulation

- Precision-feeding

- Cecectomy Surgery

- Tibia Extraction

- Tibia Mineralization
- Experience with SAS

- Data Collection

- Utilizing lab equipment such as a drying oven, ashing oven, lyophilizer, and viscometer.

- Public Speaking

- Internet Literate

- Savvy in Window's Microsoft Programs 